\title{
Relationships among felt scale insects (Hemiptera:Coccoidea:Eriococcidae) of southern beech, Nothofagus (Nothofagaceae), with the first descriptions of Australian species of the Nothofagus-feeding genus Madarococcus Hoy
}

\author{
Nate B. Hardy ${ }^{\mathrm{A}, \mathrm{E}}$, Penny J. Gullan ${ }^{\mathrm{A}}$, Rosa C. Henderson ${ }^{\mathrm{B}}$ and Lyn G. Cook ${ }^{\mathrm{C}, \mathrm{D}}$ \\ ADepartment of Entomology, University of California, One Shields Avenue, Davis, California 95616-8584, USA. \\ ${ }^{B}$ Landcare Research, Private Bag 92170, Auckland, New Zealand. \\ CSchool of Botany and Zoology, The Australian National University, Canberra, ACT 0200, Australia. \\ DPresent address: School of Integrative Biology, The University of Queensland, Brisbane 4072, Australia. \\ ECorresponding author. Email: nbhardy@gmail.com
}

\begin{abstract}
Species of southern beech (Nothofagus) have been studied extensively because of their importance in understanding southern hemisphere biogeography. Nothofagus species support a diverse assemblage of insect herbivores, including more than 30 described species of felt scales (Eriococcidae). We reconstructed the phylogeny of the Nothofagusfeeding felt scales with nucleotide sequence data and morphology. All but one of the exclusively Nothofagus-feeding species included in the analyses were recovered as a monophyletic group. This clade comprised the genera Chilechiton Hodgson \& Miller, Chilecoccus Miller \& González, Intecticoccus Kondo, Madarococcus Hoy (except for M. totorae Hoy), Sisyrococcus Hoy and several species of the genus Eriococcus Targioni Tozzetti. The genera Eriococcus and Madarococcus were not recovered as monophyletic. Here we revise Madarococcus. We expand the concept of the genus, provide a key to the adult females of the 31 species of Madarococcus and, for each named species, provide revised synonymies and any new collection or taxonomic information. We recognise the genus from Australia for the first time and describe the adult females of six new Australian species: Madarococcus cunninghamii Hardy \& Gullan, sp. nov.; M. meander Hardy \& Gullan, sp. nov.; M. megaventris Hardy \& Gullan, sp. nov.; M. moorei Hardy \& Gullan, sp. nov.; M. occultus Hardy \& Gullan, sp. nov., and M. osculus Hardy \& Gullan, sp. nov. We also describe the first-instar nymphs of M. cunninghamii, sp. nov., M. meander, sp. nov. and M. moorei, sp. nov. We transfer 17 species into Madarococcus from Eriococcus: M. argentifagi (Hoy), comb. nov.; M. cavellii (Maskell), comb. nov.; M. chilensis (Miller \& González), comb. nov.; M. detectus (Hoy), comb. nov.; M. eurythrix (Miller \& González), comb. nov.; M. fagicorticis (Maskell), comb. nov.; M. hispidus (Hoy), comb. nov.; M. latilobatus (Hoy), comb. nov.; M. maskelli, (Hoy), comb. nov.; M. montifagi (Hoy), comb. nov.; M. navarinoensis (Miller \& González), comb. nov.; M. nelsonensis (Hoy), comb. nov.; M. nothofagi (Hoy), comb. nov.; M. podocarpi (Hoy), comb. nov.; M. raithbyi (Maskell), comb. nov.; M. rotundus (Hoy), comb. nov. and M. rubrifagi (Hoy), comb. nov. We transfer two species from Sisyrococcus into Madarococcus: M. intermedius (Maskell), comb. nov. and M. papillosus (Hoy), comb. nov. One species, M. totarae (Maskell), is excluded from Madarococcus, but cannot at present be placed in another genus and is listed as ' $M$.' totarae incertae sedis. We report the first collection of an eriococcid, M. osculus, sp. nov., on the deciduous beech, Nothofagus gunnii. With respect to biogeography, the results of our phylogenetic analysis are congruent with those obtained from recent analysis of Nothofagus; Australian and New Zealand species of Madarococcus form a monophyletic group to the exclusion of the South American species, suggesting that long-distance dispersal has played an important role in shaping the distributions of both the Nothofagus-feeding felt scales and their hosts.
\end{abstract}

\section{Introduction}

Nothofagus species (southern beeches) are trees, or more rarely shrubs, showing a typical west Gondwanan distribution with species native either to Australia, New Caledonia, New Guinea, New Zealand or South America (Govaerts and Frodin 1998). No extant species are shared between any of these areas. The genus has an excellent fossil record (Hill 2001), including in Antarctica, and its phylogeny and distribution have been studied extensively because of its importance to understanding southern hemisphere biogeography (Humphries 1981; Linder and Crisp 1995; SanMartín and Ronquist 2004; Cook and Crisp 2005; Knapp et al. 2005; Heads 2006). It is the only genus in the
Nothofagaceae (previously in Fagaceae) and is sister to the remaining families in the order Fagales (Manos \& Steele 1997; Li et al. 2004). Nothofagus comprises four extant subgenera that are related as follows: (Lophozonia (Fuscospora (Nothofagus, Brassospora))) (Manos 1997). Recent molecular modelling suggests that the radiation of the current subgenera and species occurred between 55 and 40 Myr ago (Cook and Crisp 2005). Contrary to the hypothesised sequence and timing for the breakup of western Gondwana, the Australian and New Zealand taxa of both Lophozonia and Fuscospora are sister taxa, to the exclusion of species from South America. The relaxed molecular 
clock estimates for the timing of divergence of Australian and New Zealand taxa is too recent to have been a consequence of vicariance under current models (Cook and Crisp 2005; Knapp et al. 2005). Further, the divergence of taxa in New Caledonia from those in South America (Brassospora v. Nothofagus) appears too recent to be explained by vicariance (Cook and Crisp 2005). Thus, long-distance dispersal appears to have played a role in the current distribution of Nothofagus.

Diverse taxa of phytophagous insects are associated with species of Nothofagus worldwide (McQuillan 1993). Species of Lepidoptera dominate the mining guild, Lepidoptera and Coleoptera dominate the leaf-chewing guild, whereas species of Coccoidea (scale insects) greatly outnumber all other sapsucking insects (see appendix in McQuillan 1993). Within Coccoidea, over 60 species in 26 genera distributed among nine families feed on Nothofagus (Granara de Willink and Miller 2004; Kondo et al. 2006; Ben-Dov et al. 2007; Williams 2007). Over half of these species belong to the felt scales or Eriococcidae. Within the Eriococcidae, five genera and 10 species have been described from Nothofagus in Chile (Miller and González 1975; Hodgson and Miller 2002; Kondo et al. 2006), six of the species present in Chile are known also from Argentina (Miller and González 1975; Gonzalez 2004), and three genera and 24 species are known from Nothofagus in New Zealand (Hoy 1962a). No Nothofagus-feeding eriococcids have been described from any other countries, although there are specimens from Australia, New Caledonia and New Guinea in museum collections and McQuillan (1993) reported three undescribed species as monophagous on $N$. cunninghamii from Tasmania. McQuillan also reported that no scale insects were known from the deciduous $N$. gunnii, which is restricted to Tasmania. Most of the New Zealand Nothofagus-feeding eriococcids are placed in the 'catch-all' genus Eriococcus Targioni Tozzetti, but six species are in Madarococcus Hoy and two species in Sisyrococcus Hoy (Hoy 1962a). Fourteen of the 15 New Zealand Nothofagus-feeding Eriococcus species, the two species of Sisyrococcus and five of the six Madarococcus species have been recorded exclusively from Nothofagus species. The exceptions are E. brittini Hoy, which has been found also on Coprosma rotundifolia (first reported here), and Madarococcus totarae (Maskell), which has been collected mostly from Podocarpus totara and P. nivalis (Hoy 1962a). Although $M$. totarae was reported originally on both Nothofagus and Podocarpus (Maskell 1890), there are no specimens from Nothofagus in the New Zealand Arthropod Collection (Hoy 1962a) and it is likely that the record from Nothofagus is erroneous. Hoy (1962a) also listed the polyphagous Eriococcus pallidus Maskell on Nothofagus? sp. (the slide is labelled 'beech ?') but this is a misidentification of E. pallidus and these specimens are probably E. brittini. In Chile, four of the five Nothofagus-feeding Eriococcus species, the two Nothofagus-feeding species of Icelococcus Miller \& González, the monotypic genera Chilechiton lynnae Hodgson \& Miller and Intecticoccus viridis Kondo, and one of the two species of Chilecoccus Miller \& González have been recorded exclusively from Nothofagus species. Here the exceptions are Eriococus tholothrix Miller \& González and Chilecococcus spinosus Miller \& González, both of which have been recorded from Eucryphia cordifolia in addition to Nothofagus.
Hoy (1962a) first suggested a close relationship between the Nothofagus-feeding felt scales of New Zealand and Chile, a notion adopted by subsequent authors (Miller and González 1975; Williams 1985a). In the early cladistic analysis of Humphries et al. (1986), the Chilean species Eriococcus eurythrix was nested within a clade of New Zealand Nothofagusfeeding eriococcids that have spatulate suranal setae. Hodgson and Miller (2002) performed a parsimony analysis of morphological characters of the adult females of several scale insects. They recovered a polyphyletic assemblage of eriococcid species on Nothofagus and a sister relationship between the Chilean genus Chilechiton and the New Zealand genus Eriochiton. The latter result was not supported by the first molecular data (Kondo et al. 2006), which placed Chilechiton and Eriochiton in two separate clades - the Gondwanan and acanthococcid clades of Cook and Gullan (2004).

In this paper we reconstruct the phylogeny of the Nothofagus-feeding felt scales using morphology and sequence data from four nuclear loci: elongation factor-1 $\alpha(E F-1 \alpha)$; wingless $(\mathrm{wg}$ ); the large ribosomal subunit (28S); and the small ribosomal subunit (18S). We describe the adult females of six new Australian species of Nothofagus-feeding eriococcids and the first-instar nymphs of three of these species. Based on the results of the phylogenetic analyses, we place these species in the genus Madarococcus, along with four species from Chile (previously in Eriococcus) and 24 species from New Zealand (17 species transferred from Eriococcus; two species from Sisyrococcus; and five species originally described in Madarococcus). For each species belonging to the new concept of Madarococcus, we provide revised synonymies, any new collection or other data, and diagnostic notes.

\section{Materials and methods}

\section{Specimen preparation and examination}

Freshly collected specimens were slide-mounted in Canada balsam using the method described in Gullan (1984). Adult females were mounted one specimen per slide; nymphs were mounted several to a slide. Some specimens intended for molecular work were preserved in absolute ethanol and stored below $4^{\circ} \mathrm{C}$. After DNA extraction, these specimens were slidemounted as vouchers.

Specimens used for the morphological and molecular phylogenetic work are listed in Appendix 1. For taxonomic work we mostly used the museum collections of J. W. Beardsley, J. M. Hoy and W. M. Maskell as well as recent collections by P. J. Gullan (PJG), R. C. Henderson (RCH), T. Kondo and N. A. Martin, and we examined type specimens for each of the New Zealand species.

\section{Specimen depositories}

ANIC Australian National Insect Collection, CSIRO, Canberra, Australia

BME Bohart Museum of Entomology, University of California, Davis, USA (also sometimes abbreviated as UCD)

BMNH The Natural History Museum, London, UK

BPBM Bernice P. Bishop Museum, Honolulu, Hawaii, USA 
FRNZ Forest Research Institute Limited, Rotorua, New Zealand

NZAC New Zealand Arthropod Collection, Landcare Research, Auckland, New Zealand (formerly Department of Scientific and Industrial Research, or DSIR)

MNHM Museum National d'Histoire Naturelle, Paris

MEUC Museo Entomológico, Facultad de Ciencias Agronómicas, Universidad de Chile, Santiago, Chile

TASAG Tasmanian Department of Primary Industries \& Water, New Town, Tasmania

USNM National Museum of Natural History, Smithsonian Institution, housed at the United States Department of Agriculture (USDA), Beltsville, Maryland, USA (now housing VPI collection)

VPI Virginia Polytechnic Institute and State University, Blacksburg, USA (Coccoidea collection now at USNM)

ZIN Zoological Institute, Russian Academy of Sciences, St. Petersburg, Russia

All material listed in Hoy's (1962a) book, except that recorded for FRNZ, is now in NZAC and all eriococcid slidemounts in NZAC have been barcoded. The field notebook of J. W. Beardsley is held by PJG.

\section{Taxonomic descriptions and species accounts}

Full descriptions with illustrations are provided for six new species from Australia. Responsibility for the recognition and description of these new species rests solely with NBH and PJG who are joint authors of these six new names. Each of the New Zealand and Chilean species have been described and illustrated adequately by Hoy (1962a) and Miller \& González (1975). Here we provide revised synonymies, any new information on type specimens, and diagnostic notes for each of the species. Wherever available, we include additional host-plant and locality data available since publication of the orginal descriptions. For the New Zealand species, most of the new records have been provided by $\mathrm{RCH}$ and the data provided for each species are categorized under the New Zealand area codes of Crosby et al. (1998) listed from north to south.

The morphological terms for Eriococcidae follow those of Williams (1985b) and Miller and McKenzie (1967). Previous authors have used the term 'spatulate' to describe the shape of the suranal setae of the Nothofagus-feeding eriococcids (Hoy 1962a; Humphries et al.1986; Hodgson and Miller 2002). A spatulate seta is lamellate, with a slender stem gradually broadened to its apex (Torre-Bueno 1989). This term, as it is applied in the present study, encompasses a good deal of variation, especially in terms of the shape of the apex that may be truncate, rounded, acute, or have an irregular, splintered appearance (Fig. 1). On young females of some species the seta may have a very fine flagellate tip that breaks off leaving the tip variously blunt or splintered in appearance. The seta may or may not be broadest at the apex, but will never be broadest at the base. Under certain setal orientations, such as when the edge of the flattened seta is directed towards the observer, spatulate suranal setae may appear evenly attenuated (Fig. 1b).

Measurements were made using an ocular micrometer attached to a compound microscope. All measurements are maximum dimensions (e.g. body width was recorded at the widest point and leg segment lengths were measured along the longest axis) and are expressed as the range. Tarsal length excluded the claw. Spiracle length includes the muscle plate (apodeme). Setal lengths include the setal base. Values given for leg segments are lengths. Illustrations of the adult females and first-instar nymphs of the new Australian species were prepared by NBH with a drawing tube and the Adobe programs Photoshop CS and Illustrator CS. Following the convention for scale insects, each figure displays the dorsal body surface on the left side of the page, and the ventral body surface on the right. An exception was made for M. megaventris, sp. nov. Preliminary sketches of this species following the aforementioned convention proved to be both confusing (legs were on both halves of the page) and unsatisfying (the right half of the page was all but blank). Thus only the dorsal aspect was figured. Enlargements of diagnostic features are located around the margin of each main figure; the sizes of these structures are provided in the text.

\section{Morphological phylogenetic methods}

The following species (39 in total) were selected for morphological phylogenetic analysis: 1, exemplars of all known species of Eriococcidae that have spatulate suranal setae and feed exclusively on Nothofagus (28 spp. in total; $15 \mathrm{spp}$. of Eriococcus, five

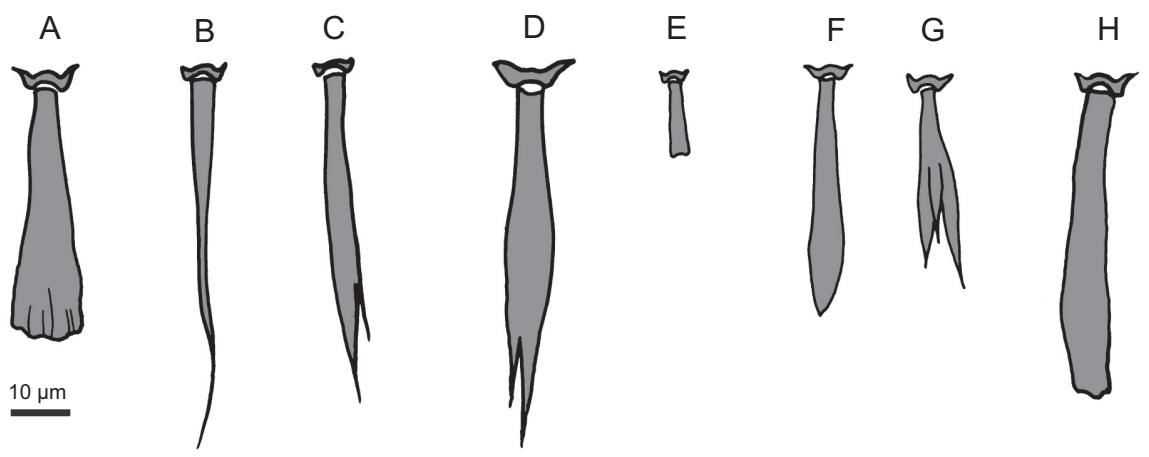

Fig. 1. Spatulate suranal setae of adult Madarococcus spp.: A, M. hispidus; $B$, M. intermedius with flattened surface perpendicular to observer; $C, M$. intermedius with flattened surface facing observer [figures $B$, and $C$, drawn from same specimen]; $D, M$. nelsonensis; $E, M$. occultus; $F, M$. osculus with acute apex; $G, M$. osculus with splintered apex; $H, M$. viridulus. 
spp. of Madarococcus, two spp. of Sisyrococcus; six undescribed spp.); 2, six Chilean species that lack spatulate suranal setae but feed on Nothofagus (Chilechiton lynnae, Chilecoccus browni Miller \& González, Eriococcus chilensis Miller \& González, E. navarinoensis Hoy, E. rhadinothrix Miller \& González and E. tholothrix Miller \& González); 3, one New Zealand species that lacks suranal setae but feeds on Nothofagus (E. brittini); 4, the one species of Madarococcus that does not feed on Nothofagus, or have spatulate suranal setae (M. totarae); 5, one species of Eriococcus from New Zealand that does not feed on Nothofagus (E. arcanus Hoy), and 6, as outgroups, two eriococcid species that fell outside of the Gondwanan clade of Cook \& Gullan (2004), one of which, Icelococcus nothofagi Miller \& González, also feeds upon Nothofagus. Whenever possible, species were scored from type material, or specimens that had been compared to type material. This was the case for all of the Australian and New Zealand species, although some type speci- mens of New Zealand species are in very poor condition and thus some microscopic features were scored from more recently collected specimens. Recent collections of the South American species were identified with the literature and, for three of the six Chilean species, with reference to paratypes in the BME and USNM. Details pertaining to the specimens used in the analysis are given in Appendix 1.

Adult females were scored for 32 characters and first-instar nymphs (crawlers) of a subset of taxa (17) were scored for an additional three characters. The character list is available in Table 1, and the data matrix is presented in Table 2 (and a NEXUS file is available as an Accessory Publication on the Invertebrate Systematics website). Phylogenies were reconstructed using Bayesian inference methods with MrBayes 3.1.1 (Ronquist \& Huelsenbeck 2003), under the mk1 model, with gamma-distributed rates and coding set to variable (Lewis 2001). Each analysis consisted of four Markov chains, three hot

Table 1. Characters used in the morphological phylogenetic analysis

Adult female:

(1) Dorsal derm: (0) membranous; (1) sclerotic

(2) Dorsal nodules: (0) rounded; (1) with acute apices

(3) Posterior abdominal segments: (0) exposed; (1) overlaid by anterior segments

(4) Dorsal macrotubular ducts (0) present, evenly distributed; (1) present, in crowded transverse rows on anterior abdominal segments; (2) absent

(5) Ductule of macrotubular ducts: (0) with apex flared; (1) with apex acinous (i.e. consisting of minute rounded lobules).

(6) Apices of spinose dorsal setae: (0) acute; (1) blunt; (2) truncate

(7) Conical dorsal setae: (0) present; (1) absent

(8) Digitate dorsal setae: (0) restricted to medial pairs on posterior abdominal segments; (1) scattered over dorsum; (2) absent; (3) arranged in one longitudinal submarginal row on each side of body

(9) Slender, slightly curved dorsal setae: (0) absent; (1) present

(10) Number of microtubular ducts at base of each spinose seta: (0) 0 ; (1) 1 ; (2) $>1$

(11) Marginal fringe: (0) present, fringe remaining tight and linear between eyes; (1) present, fringe staggered between eyes; (2) absent; pairs of enlarged setae arranged transversely on margins of posterior abdominal segments; (3) absent, largest setae present on margin; (4) absent, margin indistinct, marginal setae undifferentiated from dorsal setae

(12) Size of dorsum relative to venter: (0) equal to venter; (1) larger than venter; (2) smaller than venter

(13) Frontal lobes: (0) absent; (1) rudimentary; (2) well developed, digitate; (3) well developed, broad

(14) Number setae on apical segment of labium: (0) $>9$ pairs; (1) $<9$ pairs

(15) Numerous spinose setae ventrad of margin: (0) absent; (1) present

(16) Ventral abdominal macrotubular duct distribution: (0) present throughout submargin; (1) found across medial areas of segments; (2) absent; (3) found only posterolateral of vulva; (4) found in submedial regions, either exclusively or in addition to submarginal regions

(17) Ventral macrotubular ducts the same size as those on dorsum: (0) absent; (1) present

(18) Ventral macrotubular ducts smaller than those on dorsum: (0) absent; (1) present

(19) Bilocular pores: (0) absent; (1) present

(20) Ventral abdominal pore distribution: (0) in longitudinal series extending from lobes to coxae, absent from medial areas; (1) present in medial areas

(21) Ventral pore sizes: (0) all of one size; (2) of two sizes

(22) Size of translucent pores on hind legs: (0) small; (1) large

(23) Distribution of translucent pores: (0) restricted to hind coxae; (1) on segments of the hind legs in addition to coxae

(24) Suranal setae: (0) flagellate; (1) spatulate

(25) Apex of spatulate suranal setae: (0) blunt / truncate; (1) acute

(26) Cauda: (0) absent: (1) present

(27) Anterior dorsal surface of anal lobes: (0) simple; (1) with pit

(28) Dorsoapical lobe seta: (0) arising nearer to dorsomedial lobe seta than apical lobe seta; (1) arising nearer to apical lobe seta than dorsomedial lobe seta

(29) Number setae on ventral surface of each anal lobe: (0) 1 ; (1) 2

(30) Anal lobe cuticle: (0) relatively smooth; (1) rugose

(31) Anal plate: (0) absent; (1) present

(32) Body shape: (0) turbinate; (1) elliptical; (2) round; (3) ovate, with posterior margin forming acute angle with anal lobes

First-instar nymph:

(33) Dorsal abdominal setae: (0) minute; (1) enlarged

(34) Dorsal thoracic setae shape: (0) squat; (1) elongate

(35) Ventral lobe seta: (0) flagellate; (1) spatulate 
and one cold (program default), run simultaneously for one million generations, with trees sampled every 1000 generations, discarding the first 100 trees from the burn-in period. The analysis was repeated three times, and recovered similar parameter estimates, suggesting that stationarity had been achieved.

\section{Molecular phylogenetic methods}

Exemplars of thirty-two species were represented by sequence data (Appendix 1). Genomic DNA was extracted non-destructively from whole fresh or ethanol-stored, specimens using the 'salting out' method of Sunnucks and Hales (1996) or a DNeasy tissue kit (Qiagen, Valencia, CA, USA) following the manufacturer's instructions, except that the cuticle of each specimen was removed from the extraction mix after the digestion step. Vouchers of specimens will be deposited in the ANIC. Four nuclear gene regions (partial elongation factor-1 $\alpha(E F-1 \alpha)$, partial wingless $(w g)$, partial small subunit ribosomal rRNA (SSU rRNA, 18S) and partial large subunit ribosomal rRNA (LSU rRNA, 28S) were amplified and sequenced using the primer pairs listed in Table 3 . In addition, part of the mitochondrial small rRNA gene (12S) was amplified using primers $12 \mathrm{Sf}$ and $12 \mathrm{Sr}$ (Table 3) but was not included in analyses because of the very high level of divergence and length variation among taxa that, in addition to a very high AT bias, made alignment ambiguous. Sequencing was performed on an ABI 377 or 3100 automated DNA sequencer using BigDye chemistry, as per the manufacturer's instructions. All four gene regions could not be successfully amplified or sequenced for all relevant taxa, despite altering PCR conditions and trying different primer combinations. This is not unusual for scale insects. In addition,

Table 2. Morphological matrix

\begin{tabular}{|c|c|c|c|c|}
\hline \multirow[t]{3}{*}{ Taxon } & \multicolumn{4}{|c|}{ Characters } \\
\hline & 0000000001 & 1111111112 & 2222222223 & 33333 \\
\hline & 1234567890 & 1234567890 & 1234567890 & 12345 \\
\hline Chilecoccus browni & $0 ? 00010210$ & 4100141100 & $0110 ? 00000$ & 12??? \\
\hline Chilechiton lynnae & $0 ? 02010210$ & 0100020100 & $0110 ? 00100$ & 12??? \\
\hline Eriococcus arcanus & 0100100200 & 1100041101 & $0100 ? 01000$ & 01??? \\
\hline E. argentifagi & 0000020202 & 2010001001 & 0011001100 & $0002 ?$ \\
\hline E. brittini & 0000110201 & 4100011101 & $0100 ? 00001$ & 01??? \\
\hline E. cavellii & 0000010202 & 3020101000 & 0011000100 & 02111 \\
\hline E. chilensis & 0000011210 & 1100041101 & $1010 ? 00000$ & 01??? \\
\hline E. coccineus & 0000120100 & 1121011111 & $0000 ? 10010$ & 01??? \\
\hline E. detectus & 0002010101 & 0120001001 & 0011001101 & 02??? \\
\hline E. eucalypti & $0000 ? 12202$ & 4000040101 & $0010 ? 00000$ & 01??? \\
\hline E. fagicorticis & 0100010202 & 1010001001 & 0011100101 & 01101 \\
\hline E. hispidus & 0000020202 & 3020101001 & 0011000100 & 02111 \\
\hline E. latilobatus & $000001 ? 100$ & 1110001000 & 0011001100 & $0201 ?$ \\
\hline E. maskelli & 0100020002 & 2020001001 & 0011000100 & 01??? \\
\hline E. montifagi & 0002011100 & $01 ? 0001001$ & 0011001101 & 02??? \\
\hline E. navarinoensis & 0000011210 & 1100041101 & $1010 ? 00 ? 00$ & 01??? \\
\hline E. nelsonensis & 0000020002 & 2020001001 & 0011100100 & 00101 \\
\hline E. nothofagi & 0000020002 & 2010001001 & 0011000101 & 00011 \\
\hline E. podocarpi & 0100020202 & 3020001001 & 0011000100 & 01??? \\
\hline E. raithbyi & $00000 ? 1200$ & $10 ? 0001001$ & 0011001101 & 01110 \\
\hline E. rhadinothrix & 0000011210 & 1100041101 & $1010 ? 00000$ & 01??? \\
\hline E. rotundus & 0000021102 & 1110001000 & 0011001100 & 02011 \\
\hline E. rubrifagi & 0000020102 & 2020001001 & 0011000100 & 00??? \\
\hline E. tholothrix & 0000112200 & 4000040101 & $0010 ? 00000$ & 01??? \\
\hline Intecticoccus nothofagi & $0002 ? 10200$ & 1121020011 & $0110 ? 10011$ & 00??? \\
\hline Madarococcus cruriamplus & $0002 ? 11102$ & 0010020001 & 0011101100 & 01??? \\
\hline M. cunicularius & $1002 ? 01200$ & 1200020000 & 0011000100 & 01??? \\
\hline M. cunninghamii & 0002010202 & 3010031000 & 0011101101 & 03010 \\
\hline M. eurythrix & 0000011210 & 1110011000 & 0011000100 & 01010 \\
\hline M. maculatus & $0002 ? 10002$ & 0010020000 & 0011101100 & 01??? \\
\hline M. meander & 1000011200 & 1200020000 & $0011 ? 00100$ & 01011 \\
\hline M. megaventris & 1000001200 & 1200020001 & $0010 ? 00100$ & 01??? \\
\hline M. moorei & 0002010101 & 0110001001 & 0011000100 & 02010 \\
\hline M. occultus & 0000011210 & 1100011001 & 0011000000 & 01??? \\
\hline M. osculus & 0000001202 & 0020001000 & 0011100100 & 01??? \\
\hline M. pulchellus & $0002 ? 10201$ & 3020020001 & 0011001101 & 01??? \\
\hline M. totarae & $0002 ? 10300$ & 0130040101 & $0100 ? 00000$ & $0 ? 000$ \\
\hline M. viridulus & $0002 ? 10201$ & 3020020001 & 0011001101 & 0111? \\
\hline Sisyrococcus intermedius & $00110 ? 0102$ & 1110020001 & 0011000100 & 00010 \\
\hline S. papillosus & $00110 ? 0202$ & $4110 ? 20001$ & 0011000100 & 00??? \\
\hline
\end{tabular}


$w g$ was recovered only as multiple copies in several taxa, and these were excluded from analyses.

Sequences were edited in Sequencher v4.5 (Gibbs and Cockerill 1995) and aligned by eye using Se-Al (Rambaut 1998). Bayesian, maximum likelihood (ML) and maximum parsimony (MP) methods of phylogeny estimation all assume that base frequencies do not differ among taxa (stationarity). We therefore tested for non-stationarity using the chi-square test as implemented in PAUP* (Swofford 2003). Madarococcus pulchellus and $M$. viridulus were identical for all sequences obtained; therefore they were treated as a single composite taxon in the analyses.

Phylogenies were estimated for each dataset separately using MrBayes v3.1 (Ronquist and Huelsenbeck 2003). We used a GTR $+\mathrm{I}+\mathrm{G}$ model for each partition (defined below) and ran two simultaneous analyses of eight chains for ten million generations, sampling trees every 1000th generation. Runs were checked for convergence graphically and by comparing Harmonic means. Trees saved during the estimated burn-in period (between four and seven million generations) were discarded before further analyses.

The expansion regions of SSU and LSU rDNA of scale insects show extensive length variation, making alignment and assessment of homology among coccoids difficult. In addition, positional homology does not always equate with structural homology in scale insects (Cook unpublished data). Analyses were therefore run without the ambiguously aligned regions. We developed a secondary structure model of $28 \mathrm{~S}$ for eriococcids (Cook unpublished data) and used this to partition the data by stems, terminal loops and internal bulges. We ran analyses with and without defining these partitions. The intron-exon boundaries of $E F-1 \alpha$ were identified and the introns were excluded from further analyses because they varied in length and base composition among taxa and could not be unambiguously aligned. There were no introns present in the region of wingless amplified (390 bp). We partitioned the exon data of both $E F-1 \alpha$ and $w g$ by codon position for analysis in MrBayes. First and second positions were combined because each comprised only a few variable positions - there was a lack of power to estimate separate models - and the two positions did not differ in base composition. Third positions were assigned an independent partition. Each partition was allowed a different, unlinked GTR $+\mathrm{I}+\mathrm{G}$ model in Bayesian analyses. We also conducted an ML analysis of the $E F-1 \alpha$ data using a GTR $+\mathrm{I}+\mathrm{G}$ model with parameters estimated using Modelltest (Posada and Crandall 1998). We used 24 trees derived using MP as the starting trees for the ML heuristic search and had no further constraints.

Individual gene trees were compared to determine if there was any supported conflict between gene partitions. Gene regions were determined to be compatible and Bayesian analyses of concatenated sequence data were conducted as follows. The 'three-gene' dataset comprised 18S, 28S and $E F-1 \alpha$ and included only those taxa for which we had sequences for all three genes. Similarly, the 'four-gene' dataset comprised only those taxa for which we had all four gene regions (18S, 28S, $E F-1 \alpha, w g)$. A 1707 base-pair 'supermatrix' of all four gene regions (353bp wg, 375bp EF-1 $\alpha, 608$ bp 18S, 371bp 28S) comprised all taxa for which two or more gene regions had been sequenced. In each concatenated-data matrix, $18 \mathrm{~S}$ and $28 \mathrm{~S}$ were each allowed their own GTR $+\mathrm{I}+\mathrm{G}$ model because they had different base frequencies. Two codon-position partitions (1st + 2nd positions; 3rd position) were used for the two proteinencoding gene regions.

\section{Combined morphological and molecular phylogenetic methods}

We took two approaches to combining our morphological and DNA sequence data. First we used a 'DNA filter', in which morphological data were added only to taxa represented by sequence data in the four-gene supermatrix. We then estimated the phylogeny with a MrBayes search in which each of the previously stated DNA partitions and the morphological partition was allowed its own model. In our second approach, we used a 'DNA scaffold' to place taxa represented only by morphological data while preserving the underlying structure of the tree inferred from the sequence data (e.g. Springer et al. 2001; Manos et al. 2007). Each node recovered with $\geq 95 \%$ PP from

Table 3. Primers used in this study

The forward primer is listed first for each pair

\begin{tabular}{|c|c|c|}
\hline Primer & Sequence & Reference \\
\hline \multicolumn{3}{|l|}{$w g$} \\
\hline scale_wg_F & CTGGTTCGTGCACGACGMGRACSTGYTGGATG & This study \\
\hline modLEPWG2 & ACTICGCARCACCARTGGAATGTRCA & Brower, modified by Campbell (Brower \& DeSalle 1998) \\
\hline \multicolumn{3}{|l|}{ EFla } \\
\hline scutA_F & ATTGTCGCTGCTGGTACCGGTGAATT & This study \\
\hline $\operatorname{rcM} 52.6$ & GCYTCGTGGTGCATYTCSAC & Cho et al. (1995) \\
\hline \multicolumn{3}{|l|}{$28 \mathrm{~S}$} \\
\hline Bel28S-D2for & AGAGAGAGTTCAAGAGTACGTG & Belshaw \& Quicke (1997) \\
\hline 28S-D2rev & TTGGTCCGTGTTTCAAGACGGG & Belshaw \& Quicke (1997) \\
\hline \multicolumn{3}{|l|}{$18 \mathrm{~S}$} \\
\hline 2880 & CTGGTTGATCCTGCCAGTAG & Tautz et al. (1988) \\
\hline $\mathrm{Br}$ & CCGCGGCTGCTGGCACCAGA & von Dohlen \& Moran (1995) \\
\hline \multicolumn{3}{|c|}{ 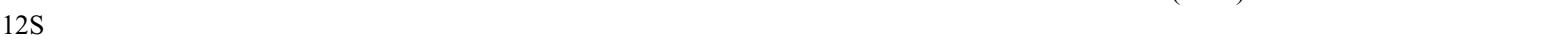 } \\
\hline $12 \mathrm{SF}$ & AACTAGGATTAGATACCCTA & This study \\
\hline $12 \mathrm{SR}$ & GACGGGCGATRTGTACA & This study \\
\hline
\end{tabular}


the analysis of the four-gene supermatrix was enforced as a backbone constraint in a Maximum Parsimony (MP) search implemented in PAUP*. If a species was represented by multiple exemplars in the DNA dataset, only one was included in the DNA scaffold analysis. Madarococcus pulchellus and $M$. viridulus also were treated as a single entity here because they were treated as a single composite taxon in the DNA analyses, and did not differ in any features used in the morphological analysis. We performed a heuristic search consisting of 100 random addition sequences followed by TBR branch swapping, with no limit placed on the number of saved trees. Support for all relationships was estimated with 100 non-parametric bootstrap replicates. Each bootstrap search was the same as that used to infer the MP tree, but with only 20 random addition sequences and no topological constraints.

\section{Results}

\section{Morphological phylogeny}

The Bayesian analysis returned a majority-rule consensus tree (Fig. $2 A$ ) having very little resolution amongst the Australian and New Zealand species, and few strongly supported relationships in general. All of the exclusively Nothofagus-feeding species except Icelococcus nothofagi were recovered as monophyletic, although with low support $(\mathrm{PP}=0.78)$. Madarococcus sensu Hoy (1962a) was not monophyletic; M. cunicularius was sister to two new gall-inducing Australian species (M. meander, sp. nov.; M. megaventris, sp. nov. $(\mathrm{PP}=0.99)$ and $M$. totarae was more distantly related to Madarococcus than several of the included Chilean species. A new Tasmanian species (M. occultus, sp. nov.) was reconstructed as sister to the Chilean E. eurythrix + the rest of the Australian and New Zealand Nothofagus-feeding species with spatulate suranal setae. Other strongly supported relationships were: 1 , the Gondwanan clade $(\mathrm{PP}=1.0) ; 2$, the Nothofagus-feeding species with spatulate suranal setae $(\mathrm{PP}=1.0) ; 3$, Sisyrococcus intermedius $+S$. papillosus $(\mathrm{PP}=1.0)$, and 4 , Chilechiton lynnae + Chilecoccus browni $(\mathrm{PP}=0.99)$.

\section{Molecular phylogeny}

Of the alignment of $1707 \mathrm{bp}$, there were 659 variable positions of which 479 were parsimony informative (Table 4). Each gene region contributed more than 100 variable characters. There was not significant non-stationarity within any of the gene regions (Table 4). However, base frequencies differed among gene partitions, and a comparison of corrected (HKY85) v. uncorrected ('p') distances suggested some saturation. Therefore, Bayesian analysis was preferred over parsimony. Bayesian phylogenetic analysis of the four-gene supermatrix returned a well resolved phylogeny, with strong support for nodes of interest (Fig. 3). Icelococcus nothofagi did not cluster with the other Nothofagusfeeding eriococcids and was the well supported sister taxon of the New Zealand genus Eriochiton (PP = 1.0). All other eriococcid taxa that feed exclusively on Nothofagus were recov-
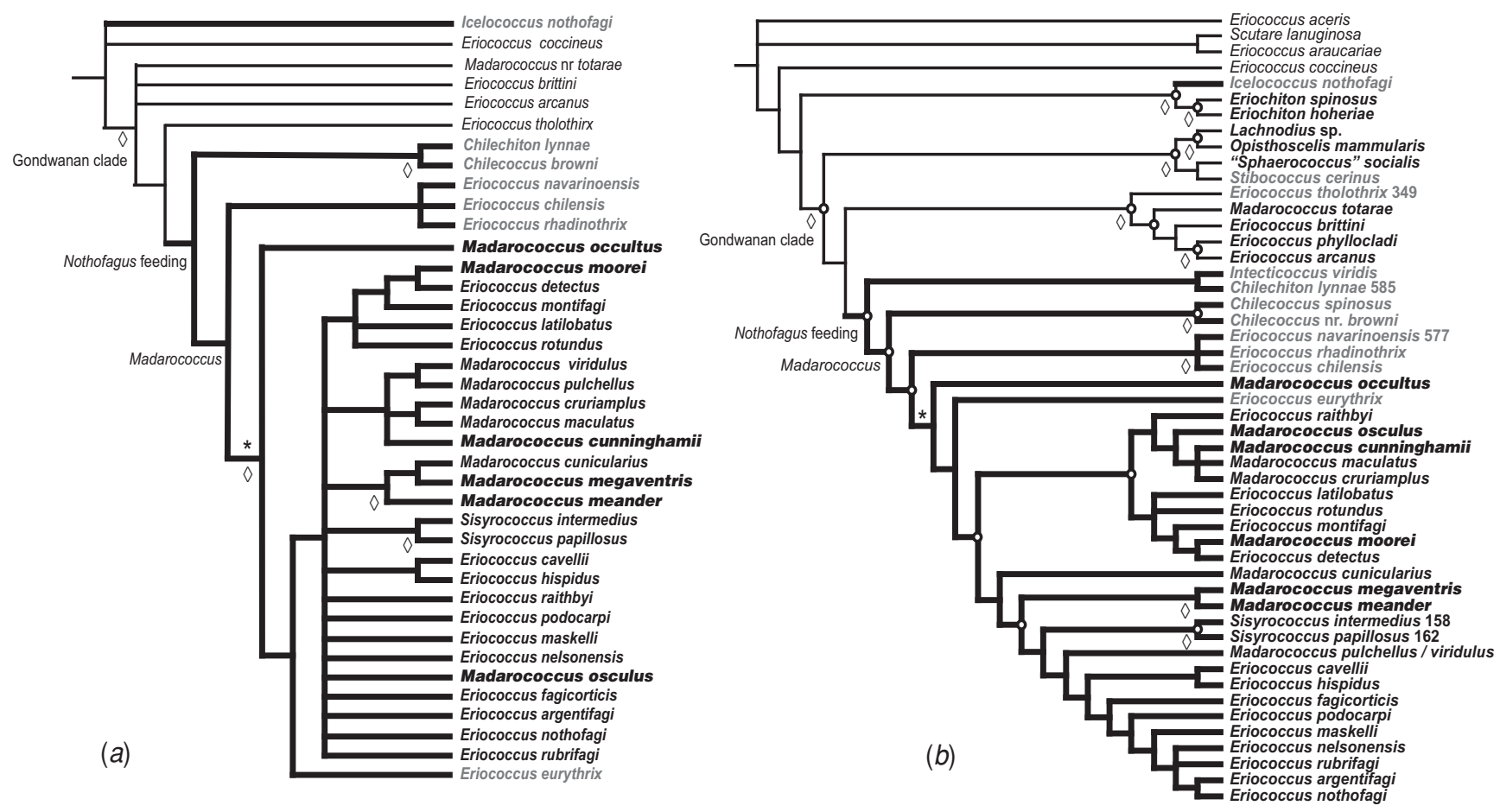

Fig. 2. A, Majority-rule consensus tree returned from Bayesian analysis of morphological data. Posterior probabilities $\geq 0.95$ represented by diamond below node. $B$, Strict consensus of MP trees recovered from DNA scaffold analysis. Open circles correspond to backbone constraint. Bootstrap proportions $\geq 0.70$ represented by diamond below node. Nothofagus-feeding taxa subtended by bold branches. Names of South American taxa in grey; names of Australian taxa black, in heavy bold; names of New Zealand taxa in black. Taxon names used on these two trees comprise those in the literature before this study as well as those of new species described herein; our broadened concept of Madarococcus is indicated by the node labelled with this genus name. An asterisk indicates the clade in which adult females have spatulate sural setae. 
Table 4. The alignment length, $X$-squared value (testing for nonstationarity), number of variable characters and number of parsimonyinformative characters for each locus

\begin{tabular}{lcccc}
\hline Gene region & $\begin{array}{c}\text { Length of } \\
\text { alignment }\end{array}$ & $X$-square & Variable & $\begin{array}{c}\text { Parsimony } \\
\text { informative }\end{array}$ \\
\hline$w g$ & 353 & 0.74 & 157 & 119 \\
$E F-1 \alpha$ exons & 375 & 1 & 146 & 129 \\
$18 \mathrm{~S}$ & 608 & 1 & 129 & 87 \\
$28 \mathrm{~S}$ & 371 & 1 & 227 & 144 \\
\hline
\end{tabular}

ered as a monophyletic group ( $\mathrm{PP}=1.0)$, falling within the Gondwanan clade previously recognised by Cook and Gullan (2004). Of these, Australian and New Zealand taxa formed a monophyletic group to the exclusion of the South American taxa $(\mathrm{PP}=1.0)$, but Australian and NZ taxa did not form reciprocally monophyletic groups because $M$. cunicularius is separated from the rest of the New Zealand taxa. The Australia-NZ cluster comprised species currently assigned to Eriococcus, Madarococcus, Sisyrococcus and the Australian taxa described in this paper. Madarococcus sensu Hoy was not monophyletic. Madarococcus totarae (podocarp-feeding, New Zealand) did not fall with other members of the genus as it is currently circumscribed, but was part of a clade from New Zealand that includes other species that also feed on podocarps (E. arcanus and E. phyllocladi) $(\mathrm{PP}=1.0)$. Sisyrococcus and some species currently assigned to Eriococcus fell within the clade of Nothofagus-feeding Madarococcus.

The above relationships were all recovered from the fourgene analysis and three-gene analysis, and none were contradicted by supported conflict in individual gene trees.

\section{Combined morphological and molecular phylogeny}

The DNA filter phylogeny inferred from the Bayesian analysis of the four-gene + morphology supermatrix (not shown) was nearly identical to that inferred from the sequence data alone. Only one realtionship strongly supported by the sequence data was not also strongly supported by the sequence + morphological data: the two species of Chilecoccus sister to E. eurythrix, E. navarinoensis, and the Australia-NZ Nothofagus-feeding species (PP = 0.88). No relationship not supported by the sequence data alone was supported with the addition of the morphological data.

The DNA scaffold MP analysis returned 416 trees, each of length 1487. The strict consensus (Fig. 2B) was well resolved, but, as was the case for the morphological analysis, support was generally low. The monophyly of the Chilean species E. chilensis, E. navarinoensis, and E. rhadinothrix was well supported $(\mathrm{BS}=0.75)$. In contrast to the molecular phylogeny, in which weak support was recovered for a sister relationship between the Chilean species E. eurythrix and E. navarinoensis, here E. eurythrix was found to be more closely related to the Australia-NZ Nothofagus-feeding species, although without bootstrap support. The new Tasmanian species, M. occultus, sp. nov., was recovered as sister to E. eurythrix + the Australia-NZ Nothofagus-feeding species $(\mathrm{BS}=0.52)$. The lack of reciprocal monophyly between the Australia and New Zealand species is more pronounced here than in the molecular phylogeny.

\section{Discussion}

We have found both morphological and molecular evidence for the monophyly of a group of more than 30 species of felt scales that feed exclusively on Nothofagus. The phylogeny inferred from morphology is largely unresolved and unsupported, but the congruence of phylogeny estimates based upon independent sources of data, along with the coincidence of Nothofagus feeding, increase our confidence in the hypothesis. This phylogenetic study further resolves the taxonomic problems surrounding Eriococcidae, and Eriococcus in particular. Several species with the generic name Eriococcus are recovered within the Gondwanan clade (Fig. 3), but we know from previous studies (Cook and Gullan 2004) that the type species of Eriococcus, E. buxi (Boyer de Fonscolombe), falls outside the Gondwanan clade and is therefore not part of the cluster. Analysis of both the morphological and sequence data reconstructed Chilechiton and Chilecoccus as sister to a clade comprised of several Eriococcus and Madarococcus species in addition to the two species of Sisyrococcus. Here we advance a broadened concept of Madarococcus for this clade. Madarococcus totarae did not cluster with the other species of Madarococcus, but rather clustered with another group of species currently ascribed to Eriococcus: the Chilean species E. tholothrix, and the New Zealand species E. arcanus, E. brittini, and E. phyllocladi. As mentioned above, E. brittini has been collected on Nothofagus solandri and Coprosma rotundifolia. The two other New Zealand species (E. arcanus and E. phyllocladi) feed exclusively on plants in the Podocarpaceae, as does M. totarae. Three described New Zealand species, which have not been included in this study, also feed exclusively on podocarps: E. dacrydii Hoy, E. matai Hoy, and E. parvulus Hoy (Hoy 1962a). Until the taxonomy of this group is revisited, we have chosen to leave $M$. totarae as incertae sedis.

More than half of the species we have included in our new concept of Madarococcus are represented in this study by only morphological data. Morphology alone was not sufficient to infer a well resolved phylogeny with confidence, and so we sought to combine our morphological and DNA sequence data. Simulation studies (Huelsenbeck 1991; Wiens 2003) have shown that analyses that include taxa with highly incomplete data with fewer than 100 characters frequently recover trees with low accuracy and resolution. In this study, we had only 35 morphological characters. Not surprisingly, our initial attempts to infer the phylogeny of Madarococcus and its relatives from a highly incomplete data matrix returned estimates with little resolution and support. Therefore, we decided to use two other methods. In our DNA filter approach, we added morphological data only for those taxa represented by sequence data. The phylogeny inferred by the DNA filter method is valuable in the sense that all available data for the included taxa were taken into consideration, but this approach does not allow us to recover relationships amongst taxa represented by only morphology. For that purpose, we used the DNA scaffold method. Our MP DNA scaffold search returned a phylogeny estimate with 25 / 29 nodes resolved within Madarococcus (only four of which were constraint nodes), a substantial improvement over the phylogeny inferred from only morphology, which recovered 15 / 30 possible nodes. Nevertheless, 
support for these relationships was low. Ideally, we would have liked to conduct a search with our data well modelled, and a backbone constraint enforced, but is not possible to enforce a backbone constraint in MrBayes. Thus, we were compelled to trade the sophisticated modelling of MrBayes for the ability to apply a backbone constraint in PAUP*.
Taking our best phylogenetic estimate to be that inferred from the DNA filter analysis, two noteworthy patterns emerge. First, multiple copies of wingless map to a single monophyletic group in the four-gene supermatrix analyses (the node spanned by $M$. megaventris, sp. nov. and E. cavellii), and all members of the clade have this feature. It appears that multiple copy $w g$ is

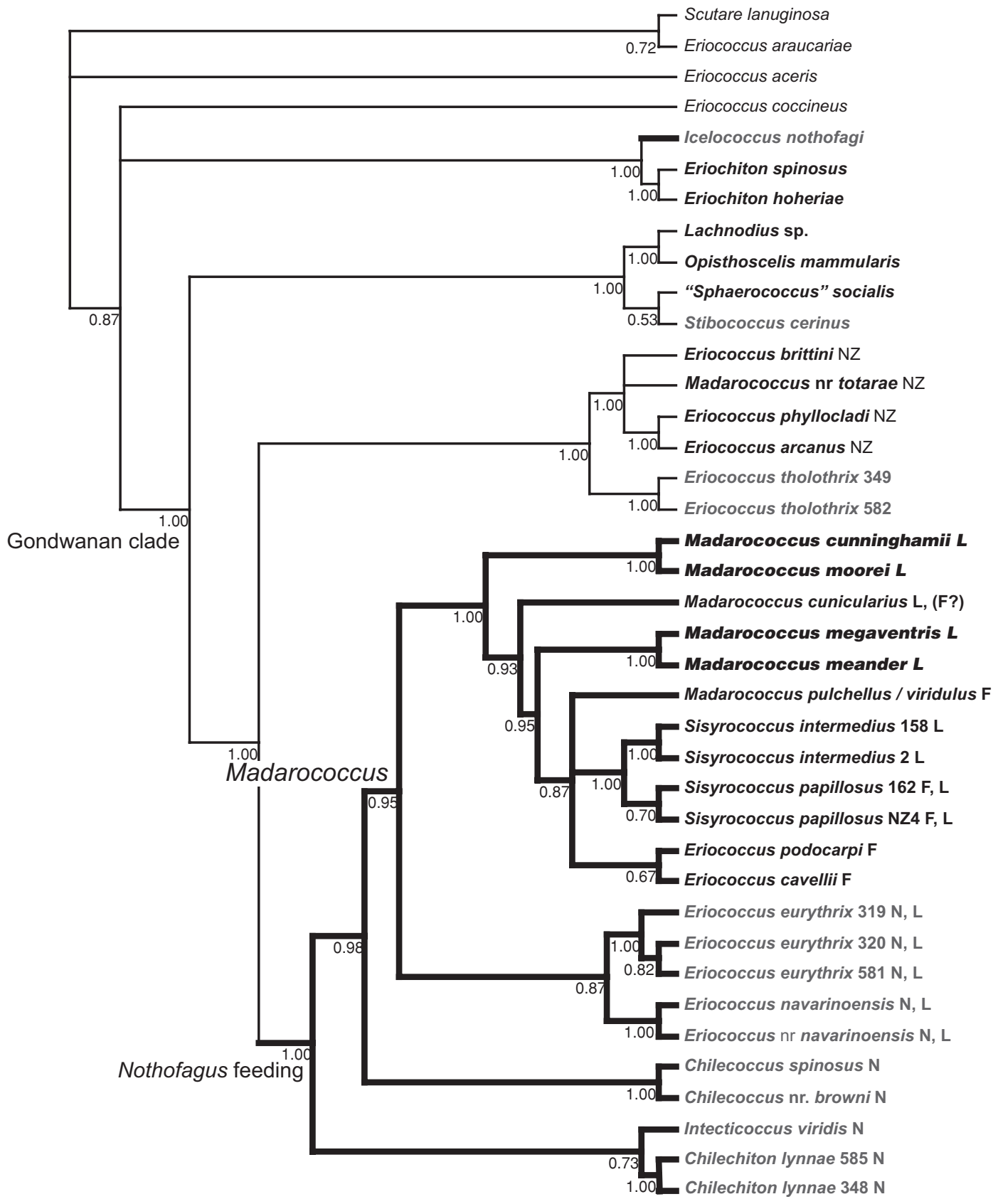

Fig. 3. Majority-rule consensus tree returned from Bayesian analysis of the DNA supermatrix. Posterior probabilities shown below each node. Nothofagus-feeding taxa subtended by bold branches. Names of South American taxa in grey; names of Australian taxa black, in heavy bold; names of New Zealand taxa in black. Taxon names comprise those in the literature before this study as well as those of new species described herein; our broadened concept of Madarococcus is indicated by the node labelled with this genus name. Each Nothofagus-feeding species is followed by an abbreviation for the Nothofagus subgenus (or subgenera) upon which it has been collected: Brassospora, B; Fuscospora, F; Lophozonia, L; and Nothofagus, N. Voucher codes are given if multiple representatives of a species are included. 
a synapomorphy for this group. Second, Madarococcus and its South American relatives show a similar biogeographic pattern to their host taxa. In both Nothofagus and the scale insects, Australian and New Zealand taxa are more closely related to each other than either is to South America taxa. This pattern is incongruent with the vicariance hypothesis that Australia and South America were joined more recently, via Antarctica, than their connections with New Zealand. Thus, it appears likely that dispersal across the Tasman Sea might have played a role in the current distribution of Madarococcus in both Australia and New Zealand.

In their morphological phylogenetic analysis, Hodgson and Miller (2002) recovered the Chilean species Chilecoccus lynnae as sister to the New Zealand tribe Eriochitonini, comprised of the genera Eriochiton and Neoeriochiton Hodgson, and they suggest expanding the tribe to include Chilechiton. Our results are congruent with those of Kondo et al. (2006), which do not support a close relationship between Chilechiton and Eriochiton.

In deciding which species to include in Madarococcus, we sought to 1 , name a monophyletic group, and 2, disturb the existing generic classification as little as possible. We also recognise the importance of a generic concept that is easy to define morphologically. In this case, reconciling the clades reconstructed by phylogeny with diagnostic morphology was not simple and so our concept is complex.

\section{Taxonomy}

\section{Genus Madarococcus Hoy}

Madarococcus Hoy, 1962a: 15, 21, 151-163, 200.

Type species: Rhizococcus pulchellus Maskell, by original designation.

\section{Diagnosis}

The adult females of 27 of the 31 species of Madarococcus can be distinguished by the spatulate shape of the suranal setae, although these can be difficult to distinguish in $M$. intermedius, comb. nov. and $M$. papillosus, comb. nov. The species that do not have spatulate suranal setae are M. chilensis, comb. nov., $M$. megaventris, sp. nov., $M$. navarinoensis, comb. nov. and $M$. rhadinothrix, comb. nov. The adult females of $M$. megaventris, sp. nov. are found within distinctive finger-shaped galls on the leaves of $N$. moorei in Australia. The ventral body surface is greatly expanded and projects forward up to several times the length of the dorsum to fill the gall cavity. The remaining three species lacking spatulate suranal setae are Chilean, and can be recognised by having two sizes of quinquelocular pores on the venter and tubular ducts on the ventral surface of the abdomen that are smaller than those on the dorsum. In all Madarococcus species (except M. occultus, sp. nov., M. chilensis, M. navarinoensis, and M. rhadinothrix) the dorsoapical (distal medial) anal lobe seta arises closer to the caudal seta than to the dorsomedial (proximal medial) anal lobe seta, although this feature is not exclusive to Madarococcus and is shared by several Eriococcus species, e.g. E. araucariae Maskell, E. celmisiae (Maskell), E. montanus Hoy and E. pimeliae Hoy. In addition, the adult females of 20 of the 31 Madarococcus species have 1-5 microtubular ducts associated with the bases of at least some enlarged dorsal setae, although this characteristic is not unique to Madarococcus. The association of enlarged dorsal and/or marginal setae with microtubular ducts occurs in several other eriococcid taxa in Australia (e.g. E. eucalypti Maskell group), Chile (Stibococcus cerinus Miller \& González; Orafortis Hardy) and New Zealand (e.g. E. brittini Hoy, E. chathamensis Hoy, E. crenilobatus Hoy, E. matai Hoy, E. multispinosus (Maskell), E. pallidus Maskell, and E. phyllocladi Maskell). An ecological characteristic uniting the species of Madarococcus is that they feed exclusively on Nothofagus species, however in South America several other eriococcids occur on Nothofagus, including Chilechiton lynnae, both Icelococcus species, both Chilecoccus species, Eriococcus tholothrix and Intecticoccus viridis (Miller and González 1975; Hodgson and Miller 2002; Kondo et al. 2006).

\section{Description}

Body shape variable: rotund, turbinate, ovate, elliptical, some species with dorsal surface of anterior abdominal segments folded over posterior abdominal segments. Eyespot on or near margin. Antennae 6- or 7-segmented. Frontal lobes (interantennal lobes) papilliform, arising adjacent to medial margin of scape; absent in some species. Labium either 3-segmented or composed of two fused segments. Legs well developed; distribution of translucent pores variable, in most species found on hind coxae, femora and proximal portions of tibiae. Vulva between abdominal segments VII and VIII. Anal ring bearing six or eight setae. Suranal setae spatulate (for definition of spatulate see Materials and Methods) on all species except M. chilensis, M. megaventris, sp. nov., M. navarinoensis and $M$. rhadinothrix. Anal lobes variable, several species have a conspicuous pit in dorsal surface near anterior margin; all lobes with three dorsal setae (dorsomedial, dorsolateral and dorsoapical), one apical seta (or caudal seta) and one ventral seta; dorsoapical seta arising closer to apical seta than dorsomedial seta except in M. occultus, sp. nov., M. chilensis, M. navarinoensis, and M. rhadinothrix.

Dorsal derm sclerotic or membranous and usually nodulose, nodules either rounded or conical. Dorsal setae ranging from minute and digitate to enlarged and spinose; apices acute, blunt or truncate. Marginal setal fringe present or absent. Quinquelocular pores absent from dorsum (except $M$. intermedius). Macrotubular ducts present or absent, if present with variably sclerotic cup-shaped vestibule and flared inner ductile. Microtubular ducts always present, 1-5 opening at bases of enlarged dorsal setae in most, but not all, species.

Ventral derm membranous. Ventral setae flagellate or spinose; in transverse rows across each abdominal segment, enlarged medial pair on each segment present or absent, scattered along margin, group of setae medial of each coxa, longitudinal band of elongate setae on medial portion of head. Venter with multilocular pores quinquelocular or trilocular; occurring on abdomen either as a submedial, longitudinal series running from anal lobes to hind coxae on each side of body, or more evenly present medially. Quinquelocular pores of one or two size-classes. Ventral macrotubular ducts present or absent. Macrotubular ducts on ventromedial surface of abdomen present or absent, if present may be distinct from those on lateral portions of venter and dorsum. Microtubular ducts along margin, or absent. 


\section{Habit}

Adult females either forming test ( $=$ sac), naked, or inducing gall (Fig. 4); found on leaf surfaces, stems, leaf axils or bark crevices. Some species with glassy filaments born on enlarged dorsal and marginal setae. Body colour varies from pale green to yellow to brown, sometimes changing with age; some species with striking white patterns on dorsum. Occurring exclusively on Nothofagus.

\section{Key to species of Madarococcus based on adult females} (drawing from the keys of Hoy (1962a) and Miller and González (1975))

1. Venter with two sizes of quinquelocular pores; suranal seta not spatulate; macrotubular ducts present on dorsum and venter, ducts on ventral surface of abdomen smaller than those on dorsum ......... 2

Venter with only one size of quinquelocular pores; suranal setae usually spatulate (Fig. 1); if macrotubular ducts present on dorsum and venter, ducts on ventral surface of abdomen same size as those on dorsum ...................... 4

2. Dorsomedial setae on abdomen each $c$. equal in length to the largest marginal setae ................. ...... M. chilensis (Miller \& González), comb. nov.

Dorsomedial setae on abdomen each noticeably shorter than largest marginal setae ............... 3

3. Antennae 6-segmented; abdominal segment $\mathrm{V}$ with 9-14 enlarged setae; ratio of hind tibia to hind tarsus $0.7-0.8$; enlarged setae on dorsomedial areas of head and thorax each $c$. same size as those along margin of abdomen ......................... ...M. rhadinothrix (Miller \& González), comb. nov.

Antennae 7-segmented; abdominal segment $\mathrm{V}$ with 19-31 enlarged setae; ratio of hind tibia to hind tarsus 0.9-1.1 enlarged setae on dorsomedial areas of head and thorax each noticeably smaller and more slender than those along margin of abdomen ............ ............... navarinoensis (Hoy), comb. nov.

4. Ventral macrotubular ducts arranged in transverse rows across abdominal segments; enlarged dorsal setae curving slightly; from South America or Australia . . 5

Ventral macrotubular ducts (if present) never found in medial portions of abdominal segments; enlarged dorsal setae straight or absent; from Australia or New Zealand ....................... 6

5. Anal ring with eight setae; translucent pores on hind legs c. $1 \mu \mathrm{m}$ in diameter; from South America. ......... ...... M. eurythrix (Miller \& González), comb. nov.

Anal ring with six setae; translucent pores on hind legs c. $5 \mu \mathrm{m}$ in diameter; from Australia ............. ..... M. occultus Hardy \& Gullan, sp. nov. (Fig. 12)

6. In life, dorsal surface of anterior abdominal segments folded back over posterior abdominal segments, anal lobes concealed from above; dorsal macrotubular ducts arranged into tight transverse lines on anterior abdominal segments .................. 7 Abdomen and dorsal macrotubular ducts not as above. . 8
7. Enlarged setae forming marginal fringe, most distinct on posterior abdominal segments, setae becoming more irregularly positioned cephalad, only a few similar setae found on dorsum; narrow band of quinquelocular pores on dorsomedial surface of head ...... ............ M. intermedius (Maskell), comb. nov.

No distinct marginal fringe present, $c$. 500 enlarged setae covering dorsum; quinquelocular pores absent from dorsal surface of head . . . . . . . . . . . . . . . ................ Mapillosus (Hoy), comb. nov.

8. Dorsal derm sclerotic; venter larger than dorsum in mature specimens; all dorsal setae inconspicuous, submedial setae lacking from majority of abdominal segments; inducing galls................ 9

Dorsal derm membranous; size of venter less than or equal to that of dorsum in mature specimens; submedial setae present on majority of abdominal segments; inducing galls or not ................. 11

9. Suranal setae flagellate; venter extending anterad for distance much greater than that between eyes and anal lobes; macrotubular and microtubular ducts scattered over dorsum. ....................... ...M. megaventris Hardy \& Gullan, sp. nov. (Fig. 9) Suranal setae spatulate; venter larger than dorsum, but not directed anteriorly for a distance greater than that between eyes and anal lobes; macrotubular or microtubular ducts confined to margin ........... 10

10. Macrotubular ducts present on dorsum just mesad of margin; only one marginal seta present on each side of each abdominal segment; anal lobes with truncate apices and inner margin straight, parallel to longitudinal body-axis. . . . . . . . . . . . . . . . . . ......M. meander Hardy \& Gullan, sp. nov. (Fig. 7)

Microtubular ducts present on dorsum just mesad of margin; multiple marginal setae present on each side of each abdominal segment; anal lobes conical ..... ....................... cunicularius Hoy

11. Dorsal macrotubular ducts absent, in life not forming a test ......................... 12

Dorsal macrotubular ducts present, in life forming a test or partial test..................... 19

12. Ventral macrotubular ducts either absent or limited to a pair on either side of abdomen posterolateral of vulva ........................ 13

Ventral macrotubular ducts found throughout submarginal zones .................... 17

13. Ventral macrotubular ducts present posterolateral of vulva; caudal seta shorter than dorsoapical lobe seta; posterior body margin near anal lobes curving slightly cephalad ........................... .. M. cunninghamii Hardy \& Gullan, sp. nov. (Fig. 5)

Ventral macrotubular ducts completely absent; caudal seta longer than dorsoapical lobe seta; body shape elliptical .......................... 14

14. Most or all enlarged dorsal setae on margin; anal lobes as broad at base as long; dorsal pit near anterior margin of each anal lobe absent or inconspicuous . . . . . 15 
Dorsum densely beset with enlarged setae; anal lobes longer than basal width; dorsal pit near anterior margin of each anal lobe well developed . . . . . . 16

15. Enlarged setae confined to margins; minute setae scattered over dorsum. . . . . . . . . . cruriamplus Hoy

Enlarged setae present on dorsum, in one medial and one submedial row on each side of body; minute dorsal setae confined to posterior abdominal segments .... .................. maculatus (Maskell)

16. Dorsal setae of two distinct size classes. . . . . . . . . ..................... viridulus Hoy

Dorsal setae may vary slightly in size, but not in two discrete classes ............. pulchellus (Maskell)

17. Enlarged setae completely absent from dorsum ....... ............... montifagi (Hoy), comb. nov.

Enlarged setae present on dorsum . . . . . . . . 18

18. Dorsal surface of each anal lobe with conspicuous pit near anterior margin; translucent pores present on proximal portions of hind tibiae . . . . . . . . . ................ detectus (Hoy), comb. nov.

Dorsal surface of each anal lobe simple, without conspicuous pit near anterior margin; translucent pores absent from hind tibiae. . . . . . . . . . . . . . . ...... M. moorei Hardy \& Gullan, sp. nov. (Fig. 10)

19. Flagellate setae present on dorsal surface of head and thorax; anal lobe cuticle extremely rugose, lateral lobe seta minute. . . . . . M. raithbyi (Maskell), comb. nov.

Flagellate setae never present on dorsum; anal lobe cuticle and lateral lobe seta variable, but generally not as above. . . . . . . . . . . . . . . 20

20. Labium composed of two fused segments, basal segment absent; length of antennal segment III > combined length of segments I + II; Australia . . . . . . . . . . ... . . . M. osculus Hardy \& Gullan, sp. nov. (Fig. 13)

Labium 3-segmented, basal segment indicated by basal segment setae; length of antennal segment III $<$ combined length of segments I + II; New Zealand . . . . 21

21. Marginal fringe present, represented by several setae on each abdominal segment. . . . . . . . . . . 22

Marginal fringe absent, although one enlarged marginal seta may be present on each side of each abdominal segment.................... 24

22. Enlarged dorsal setae present on abdomen in addition to head and thorax; marginal fringe disintegrating cephalad; dorsal derm with conical nodules . . . . . . . . . . ........... fagicorticis (Maskell), comb. nov.

Enlarged dorsal setae, if present, restricted to head and thorax; marginal fringe complete, becoming only slightly staggered along anterior margin of head; dorsal derm nodules rounded . . . . . . . . . . . 23

23. Enlarged dorsal setae no more than four in number .... ................ rotundus (Hoy), comb. nov.

Enlarged dorsal setae greater than 10 in number. . . . . . . . . . . . . . . M. latilobatus (Hoy), comb. nov.

24. Numerous spinose setae present ventrad of margin. . 25 Spinose setae confined to dorsum and margin .... . 26

25. Majority of disc pores trilocular; ventral abdominal setae flagellate, longest setae 35-50 $\mu \mathrm{m}$ long; width of hind coxae less than $1.5 \times$ width of mid coxae . . . . . . . ............... hispidus (Hoy), comb. nov.

Majority of disc pores quinquelocular; ventral abdominal setae robust, longest setae 15-25 um long; width of hind coxae greater than $1.5 \times$ width mid coxae . . . . . ............... cavellii (Maskell), comb. nov.

26. Antennae 6-segmented; caudal seta shorter than dorsoapical lobe seta . . . . . . . . . . . . . . . . . . . . . nothofagi (Hoy), comb. nov.

Antennae 7-segmented; caudal seta much longer than dorsoapical lobe seta. . . . . . . . . . . . . 27

27. Anal ring with six setae; ventral macrotubular ducts confined to abdominal margins and area between antennae . . . . . . . . . M. nelsonensis (Hoy), comb. nov.

Anal ring with eight setae; ventral macrotubular ducts throughout submarginal zone . . . . . . . . 28

28. Dorsal setae on head and thorax all more or less same size; dorsal derm with conical nodules . . . . . . . . 29

Dorsal setae on head and thorax of various sizes, some less than half length of others; dorsal derm with rounded nodules . . . . . . . . . . . . . 30

29. All dorsal setae on abdomen approximate in size to those on head and thorax, submedial setae present on abdominal segments VI and VII; more than 10 translucent pores on each hind femora ........... ............... maskelli (Hoy), comb. nov.

Dorsal medial pairs of setae on abdominal segments VI and VII much smaller than those elsewhere on body, dorsal submedial setae absent from abdominal segments VI and VII; less than 10 translucent pores on each hind femora. . . . . . . . . . . . . . .............. podocarpi (Hoy), comb. nov.

30. Dorsal setae truncate, with broad, concave apices...... ............. argentifagi (Hoy), comb. nov.

Dorsal setae more evenly attenuated, apices appearing blunt or truncate, but not concave. . . . . . . . . . .............. rubrifagi (Hoy), comb. nov.

\section{Madarococcus argentifagi (Hoy), comb. nov.}

Eriococcus argentifagi Hoy, 1962a: 31, 44-45, fig. 8. Type data: New Zealand: South Island, Southland, Purakaunui Falls, on Nothofagus menziesii, 11.xi.1958, J. M. Hoy. Holotype and six paratype females, by original designation. Type depository: NZAC.

Acanthococcus argentifagi; Miller \& Gimpel, 1996: 598. Change of combination.

\section{Remarks}

The Hoy collection includes one slide of a second-instar female with the same data as the holotype, but it is not labelled as a paratype and was not included in the type series. Hoy (1962a) described the adult female of $M$. argentifagi as lacking translucent pores on the hind legs, but translucent pores are present. Madarococcus argentifagi is very similar to M. rubrifagi. A distinction can be made between the two species on the basis of the apices of the enlarged dorsal setae: truncate, with broad concave apices in $M$. argentifagi, as opposed to blunt or truncate but never with concave apices in M. rubrifagi. It is possible these two collections represent a single species. Perhaps the slight 

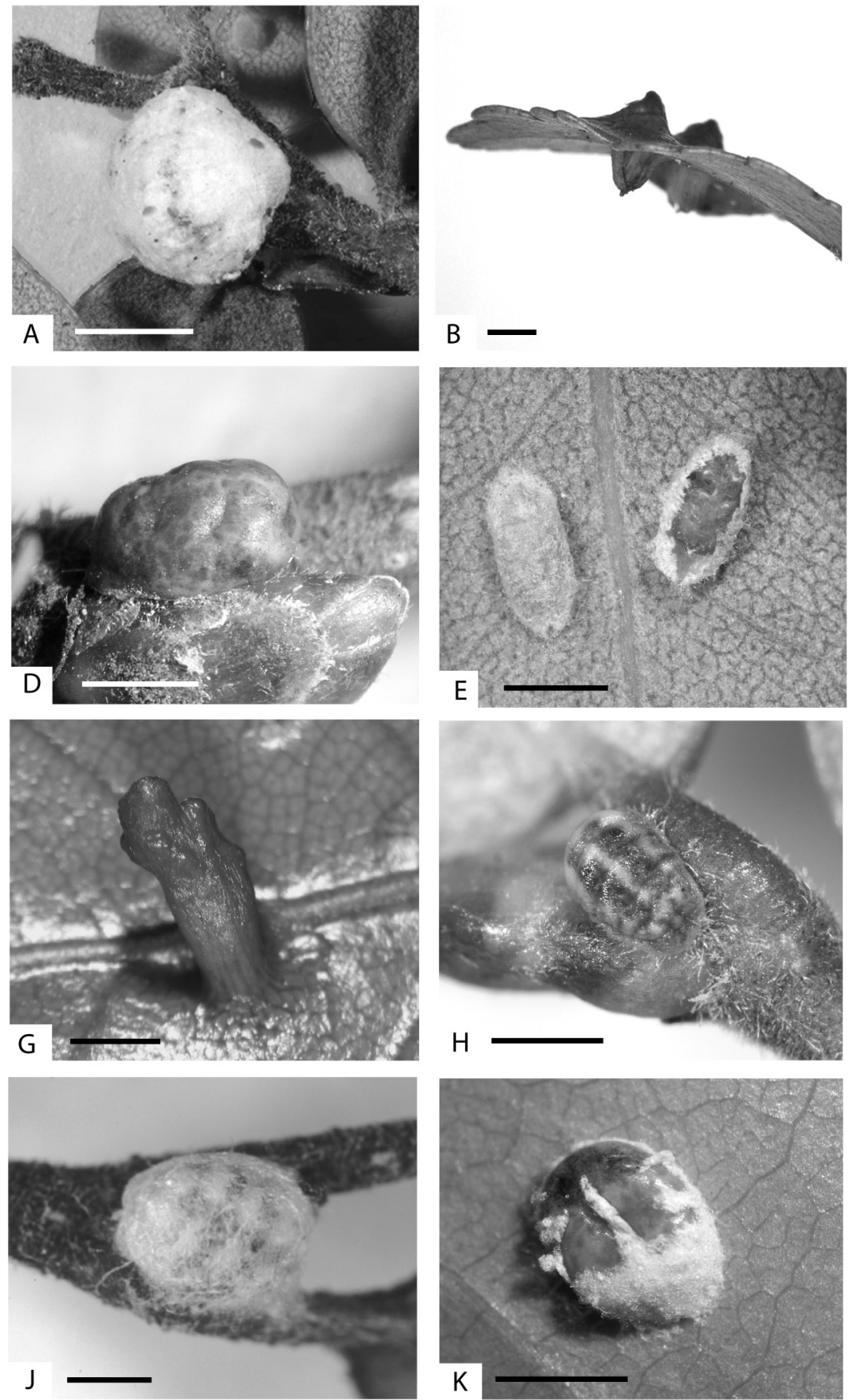

B
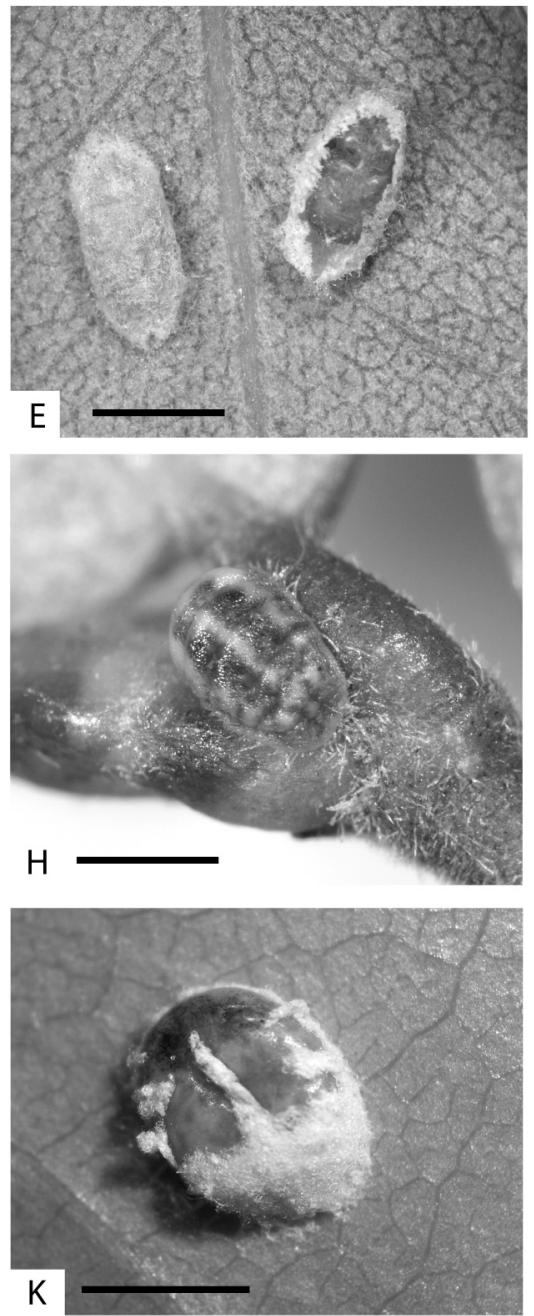
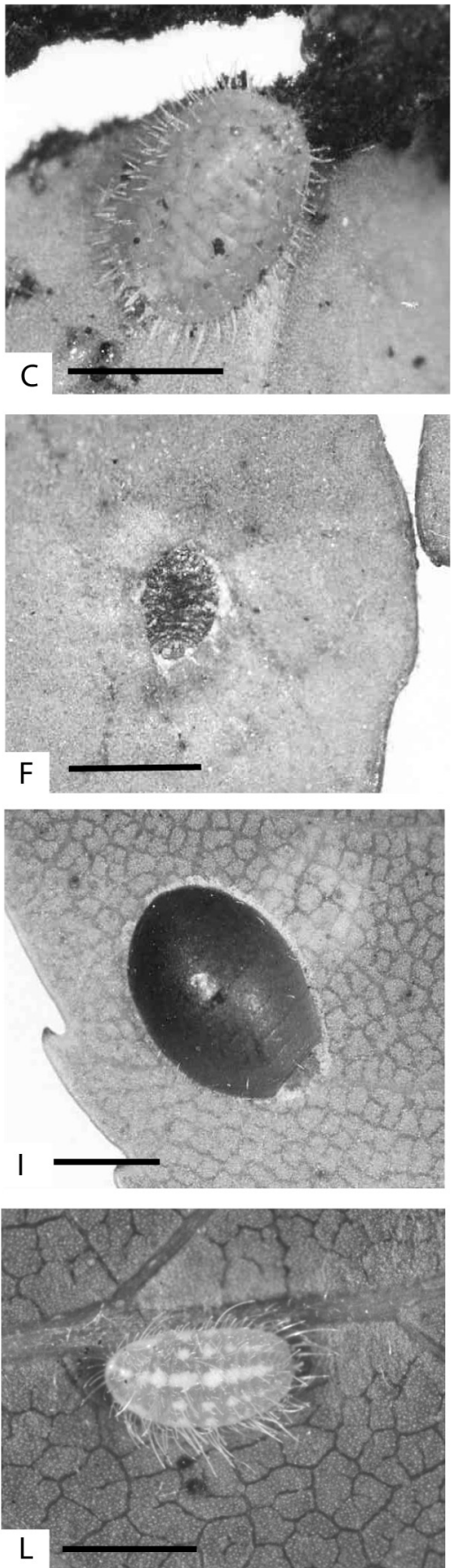

Fig. 4. Adult females of Madarococcus spp. in life: A, M. cavellii with test, on Nothofagus solandri; B, M. cunicularius, lateral view of leaf of $N$. menziesii with two pouch galls; $C, M$. cunninghamii on leaf base of $N$. cunninghamii; $D$, M. intermedius, ex N. menziesii, mature female on leaf axil; E, M. maskelli on leaf of $N$. solandri, two females (one upturned), each with test; $F, M$. meander, dorsum flush with abaxial surface of leaf of N. cunninghamii, expanded venter occupying gall cavity (not shown); G, gall of M. megaventris on leaf of N. moorei; H, M. montifagi on $N$. solandri, young female in leaf axil (mature females may feed on leaves); I, M. moorei on leaf of $N$. moorei, mature specimen (younger females feed in leaf axils); J, M. nelsonsensis in lightly woven test on twig of $N$. fusca; $K$, . . rotundus on leaf of $N$. fusca, mature female with distinctive wax pattern; $L, M$. viridulus on leaf of $N$. fusca. Scale bars $=1 \mathrm{~mm}$. 
morphological variation can be attributed to the effects of feeding on different hosts, $M$. argentifagi on $N$. menziesii and M. rubrifagi on N. fusca. Madarococcus argentifagi is also similar to M. nelsonensis and M. nothofagi [see comments under M. nothofagi]. The adult females of M. argentifagi can be distinguished from those of $M$. nelsonensis by 1 , lacking quinquelocular pores between hind coxae (several present in M. nelsonensis), and 2, having hind legs approximately same size as fore and mid legs (hind legs much larger than fore or mid legs in M. nelsonensis). Adult females of $M$. argentifagi differ from those of M. nothofagi by having 1 , caudal seta longer than dorsoapical lobe seta (caudal seta shorter than dorsoapical lobe seta in $M$. nothofagi) and 2, 7-segmented antennae (6-segmented in M. nothofagi).

Madarococcus cavellii (Maskell), comb. nov.

(Fig. 4A)

Gossyparia cavellii Maskell, 1890: 147-149, pl. VII, figs 13-22. Type data: New Zealand: North Island, Rimutaka Mountains, near Wellington; South Island, Capleston, near Reefton; on N. menziesii (as Fagus menziesii). Lectotype female, by subsequent designation of Deitz \& Tocker, 1980: 45. Type depository: NZAC.

Gossyparia cavellei; Fernald, 1903: 68. Misspelling of species name.

Nidularia cavellii; Lindinger, 1933: 108. Change of combination.

Eriococcus cavellii; Hoy, 1962a: 6, 22, 31, 52-53, fig. 12. Change of combination.

Acanthococcus cavellii; Miller \& Gimpel, 1996: 599. Change of combination.

\section{Material examined}

New Zealand: NN, Nelson, Church Hill, N. solandri; KA, Puhipuhi River, N. ?solandri (NZAC); MC, Klondyke Corner, in stem axil of N. solandri (ANIC); MC, Banks Peninsula, Hinewai Reserve, N. fusca stems in leaf bud axils, some with galls (NZAC); MC, Christchurch, Riccarton Rd (lower), $N$. fusca at nodes with stem swelling and $N$. solandri stems at nodes (NZAC); MC, Craigieburn Forest Park, N. solandri stems (NZAC); DN, Dunedin, Otago Museum Reserve, [no host] (NZAC); DN, Dunedin, Woodhaugh Gardens, $N$. solandri (NZAC).

\section{Remarks}

Hoy (1962a) illustrated and redescribed the adult female of this species. RCH discovered that Maskell's dry material of this species (slide-mounted by Hoy for his $1962 a$ revision) had been a mixed series of both M. cavellii and M. nelsonensis (Henderson $\&$ Martin 2006). Thus there is some uncertainty concerning whether Maskell (1890) and later Hoy (1962a) accidentally described the test of $M$. nelsonensis as if it belonged to M. cavellii. Maskell (1890: 147) described the adult female of E. cavellii as dark purple in colour and 'resting on a cushion of yellowish or grayish cotton, with filaments of the same more or less sparsely covering the dorsum; sometimes the body of the insect is quite clearly visible through the threads, at others it is scarcely to be seen'. Maskell's description of the wax is consistent with the distribution and density of the macrotubular ducts seen on the dorsum as well as the ventral submargin of the adult female, except that the almost complete covering of some females by their test might be based on M. nelsonensis. A further complication is that recent collections by N. A. Martin and RCH show that there is some variation among populations of $M$. cavellii in the degree of waxy covering and stem distortion caused by the adult female depending on its Nothofagus host and its locality. On $N$. fusca at Banks Peninsula, females of E. cavellii are naked and sit on a cushion swelling at the stem nodes (Henderson and Martin 2006, Fig. 14), causing the young stems to appear knotty, whereas on $N$. fusca at Christchurch, the females have some cottony covering but cause little stem swelling; on $N$. solandri at Christchurch, females have a white loose covering (Fig. 4A) and no obvious associated stem swelling. Maskell (1890) noted that feeding by females of $M$. cavellii affected the stem axils of $N$. menziesii. It is not known whether the differences described above are host effects or reflect genetic variation among the insect populations. On females from the Banks Peninsula, the dorsal setae are size-restricted anteriorly, perhaps due to "pressure' of the leaf bud covering that part of the insect, as the female has its head resting against the axil.

Madarococcus cavellii is most easily confused with M. hispidus. Both species are characterised by numerous spinose setae on the lateral areas of the venter. This feature is apparent even on the first-instar nymphs of $M$. cavellii (all ventral setae are minute and slender in the first-instar nymphs of M. hispidus). The adult female of $M$. cavellii can be distinguished from that of M. hispidus by 1 , hind coxae much larger than fore or mid coxae (coxae of all legs subequal in M. hispidus); 2, majority of ventral disc pores quinquelocular (most disc pores trilocular in M. hispidus), and 3, ventral abdominal setae short and robust (longer and flagellate in M. hispidus).

\section{Madarococcus chilensis (Miller \& González) \\ Eriococcus chilensis Miller \& González, 1975: 140-142, Fig. 4. Type data: Chile: Magallanes, Puerto del Hambre, on N. betuloides, 18.xii.1971, R. González. Holotype and eight paratype females, by original designation. Type depositories: MEUC; BMNH; USNM.}

\section{Material examined}

Chile: Parque Nacional Puyehue, Antillanca Ski Resort, on underside of leaves of N. pumilio (ANIC, BME).

\section{Remarks}

The adult females of $M$. chilensis are very similar to those of $M$. navarinoensis and $M$. rhadinothrix, each having 1 , two sizes of quinquelocular pores on the venter; 2 , macrotubular ducts on the ventromedial surface of the abdomen that are smaller than those on the dorsum, and 3, dorsoapical anal lobe setae that are closer to or as close to the dorsomedial setae as to the caudal setae. The adult females of M. chilensis can be separated from the other two species by the presence of dorsomedial abdominal setae that are approximately the same as the largest marginal setae, however there can be some variation in the lengths of the dorsal setae even among specimens from one locality. The morphological delimitation of these three species given by Miller and González (1975) requires further study.

\section{Madarococcus cruriamplus Hoy}

Madarococcus cruriamplus Hoy, 1962a: 151-153, fig. 61. Type data: New Zealand: South Island, Maruia Springs, on Nothofagus sp., 10.xi.1935, G. Brittin; Maruia, on Nothofagus sp., xii.1935, 
G. Brittin. Holotype and four paratype females, by original designation. Type depository: NZAC.

\section{Material examined}

New Zealand: BR, Alfred River, Lake Daniells Track, N. fusca leaves (NZAC).

\section{Remarks}

Madarococcus cruriamplus appears to be closely related to M. maculatus [see comments under M. maculatus]. The adult females are green in life and lack a test.

\section{Madarococcus cunicularius Hoy}

(Fig. 4B)

Madarococcus cunicularius Hoy, 1962a: 151, 154-155, 204, fig. 62. Type data: New Zealand: North Island, Rangataua, on N. menziesii, 08.ii.1960, J. M. Hoy. Holotype and 15 paratype females, by original designation. Type depository: NZAC.

\section{Material examined}

New Zealand: NN, Golden Downs, leaf galls on N. menziesii (NZAC); NN, Korere-Tophouse Road, near Tophouse T-junction, leaf galls on N. menziesii (NZAC); BR, near St Arnaud, Mt Robert, leaf galls on N. menziesii (ANIC).

\section{Remarks}

Hoy (1962a) provides an additional host record: G. Brittin collected M. cunicularius from $N$. fusca. The adult female of $M$. cunicularius is pale yellow in colour and completely encased in its gall (Fig. $4 B$ ) with an irregular abaxial opening formed by striated, finger-like projections of host tissue. The gall is described and illustrated by Henderson and Martin (2006). Madarococcus cunicularius most closely resembles $M$. meander, sp. nov., which induces open-pit galls, although the molecular data do not support a sister-group relationship between these two species. For discussion of the morphological similarities of M. cunicularius and M. meander, sp. nov. see comments under M. meander, sp. nov.

Madarococcus cunninghamii Hardy \& Gullan, sp. nov. (Figs $4 C, 5,6)$

Madarococcus sp.: McQuillan, 1993: 349 (as undescribed).

\section{Material examined}

Holotype. Tasmania: 1 adult female: Ridgley, $41^{\circ} 10^{\prime} \mathrm{S}, 145^{\circ} 50^{\prime} \mathrm{E}$, on leaf of ornamentally planted tree of $N$. cunninghamii, 29.i.1996, D. W. deLittle (ANIC).

Paratypes. Tasmania: 6 adult females, 1 second-instar female and c. 30 first-instar nymphs (three slides): same data as holotype (ANIC); 9 adult females and 4 first-instar nymphs (one slide): same data as holotype except 17.i.1996 (ANIC); 2 adult females: Collinsvale, 500 m, 2.v.1981, M. Williams, 50 B6, Record 69893 (TASAG); 18 adult females: Davis Creek, 39 miles [63 km] E of Queenstown, on N. cunninghamii, 27.vi.1971, J. W. Beardsley (BPBM); 3 adult females: Fern Tree, on N. cunninghamii, 21.i.1962, N. M. Hudson (BMNH); 9 adult females (five slides): Hellyer's Gorge, on leaf of Nothofagus, [no date], J. M. Cox \# 275 (BMNH); 17 adult females (four slides): 20 miles [32 km] W of Maydena, on N. cunninghamii, 26.vi.1972. J. W. Beardsley (BPBM); 10 adult females: Meander State Forest, picnic area, $41^{\circ} 43^{\prime} 03^{\prime \prime} \mathrm{S}, 146^{\circ} 34^{\prime} 04^{\prime \prime} \mathrm{E}$, on leaves of $N$. cunning- hamii, 24.i.2006, PJG (six slides ANIC, two slides TASAG, two slides USNM); 4 adult females: Mt Barrow, on leaf of Nothofagus, 17.ii.1973, J. M. Cox \#279 (BMNH); 3 adult females: Mt Field N.P., information centre, on leaves of N. cunninghamii, 7.ii.1992, PJG and T. K. Qin (ANIC); 13 adult females: Mt Field N.P., 42 $40^{\prime} 17^{\prime \prime}$ S, 146 $40^{\prime} 50^{\prime \prime} \mathrm{E}$, on leaves of N. cunninghamii, 23.i.2006, PJG (seven slides ANIC, three slides TASAG, three slides USNM); 1 adult female and 5 embryos: Mt Field N.P., Lyrebird Walk, 680 m, ex N. cunninghamii, 10.iv.2000, P. J. Keble-Williams, HeEr1 (TASAG); 1 adult female: $c .2 \mathrm{~km} \mathrm{~N}$ of St Columba Falls, $41^{\circ} 18^{\prime} 39^{\prime \prime} \mathrm{S}, 147^{\circ} 56^{\prime} 02^{\prime \prime} \mathrm{E}$, on leaf of $N$. cunninghamii, 26.i.2006, PJG (ANIC); 3 adult females: near Strahan, 28.vi.1972, J. W. Beardsley (BPBM); 4 adult females (two slides): Tahune Forest Park, on N. cunninghamii, 18.xi.1978, M. A. Williams (BMNH); 3 adult females: $10 \mathrm{~km} \mathrm{SSE}$ of Weldborough, $41^{\circ} 13^{\prime} \mathrm{S}, 147^{\circ} 56^{\prime} \mathrm{E}$, ex leaves of $N$. cunninghamii, 26.i.2006, PJG (ANIC). Victoria: 6 adult females (two slides): Donna Buang, on N. sp., 3.xi.1963, S. W. Brown (ANIC); 13 adult females (13 slides): 8 or 10 miles [13 or $32 \mathrm{~km}$ ] E of Marysville, on N. cunninghamii, 19.x.1971, J. W. Beardsley (BPBM); 1 adult female and 1 second-instar male (one slide) and 1 second-instar male and 1 first-instar nymph (one slide): Otway Ranges, at base of leaf underside on N. cunninghamii, 27.x.1971. J. W. Beardsley, V-162 (BPBM).

\section{Description}

\section{Adult female (Fig. 5)}

Live material. Occurring on underside of leaf near petiole (Fig. 4C). Body colour bright green, some specimens with longitudinal bands of brown cuticle, others with dorsum entirely brown. Glassy filaments (maximum length $0.2-0.3 \mathrm{~mm}$ ) born on enlarged setae, projecting dorsally and marginally.

Mounted material. Body outline ovate to subcordate, length $0.96-2.25 \mathrm{~mm}$ (holotype $1.70 \mathrm{~mm}$ ), greatest width $0.58-1.80 \mathrm{~mm}$ (holotype $1.34 \mathrm{~mm}$ ). Eyespot on or just dorsad of margin, 15-20 $\mu \mathrm{m}$ wide. Antennae 6-segmented; length 100-155 $\mu \mathrm{m}$; with three hair-like setae (trichoid sensilla) on segment I, two hair-like seta on II, two hair-like setae on III, one fleshy seta on IV, three hair-like setae and one fleshy seta on V, and $c$. six hair-like setae plus three fleshy setae on VI. Frontal (interantennal) lobes present, sometimes difficult to detect. Tentorial box 100-112 $\mu \mathrm{m}$ long, 98-112 $\mu \mathrm{m}$ wide. Labium 50-62 $\mu \mathrm{m}$ long, 60-82 $\mu \mathrm{m}$ wide; basal segment lost, apical two segments fused; five pairs of setae on anterior surface, one pair of setae on posterior surface, and one apical pair of short setae. Spiracles 32-42 $\mu \mathrm{m}$ long, 13-20 $\mu \mathrm{m}$ wide across atrium. Legs increasing in size caudad; fore legs: coxa $32-40 \mu \mathrm{m}$, trochanter + femur 100-107 $\mu \mathrm{m}$, tibia 40-60 $\mu \mathrm{m}$, tarsus 62-70 $\mu \mathrm{m}$; mid legs: coxa $35-42 \mu \mathrm{m}$, trochanter + femur $102-120 \mu \mathrm{m}$, tibia 45-55 $\mu \mathrm{m}$, tarsus 65-72 $\mu \mathrm{m}$; hind legs: coxa 50-62 $\mu \mathrm{m}$, trochanter + femur 105-130 $\mu \mathrm{m}$, tibia 47-60 $\mu \mathrm{m}$, tarsus 75-85 $\mu \mathrm{m}$; claw $15 \mu \mathrm{m}$ long; fore coxa with six setae, mid and hind coxa each with five setae, trochanter and femur with four setae (long seta on trochanter 47-50 $\mu \mathrm{m}$ ), tibia with three setae, and tarsus with five setae; tarsal digitules 21-28 $\mu \mathrm{m}$ long; claw digitules unequal 16-19 $\mu \mathrm{m}$ long, one with apical knob $6 \mu \mathrm{m}$ wide, other with apical knob $2 \mu \mathrm{m}$ wide; translucent pores on both surfaces of hind coxa and femur, dorsal and ventral surfaces of hind coxa each with $c .50$ pores, dorsal and ventral surfaces of hind femur with c. 20 and 10 pores respectively. Anal ring 50-64 $\mu \mathrm{m}$ wide, bearing eight setae, 120-170 $\mu \mathrm{m}$ long. Suranal setae spatulate, $70-85 \mu \mathrm{m}$ long. Anal lobes subclavate, with distal portion of inner margin crenulate, invested with $\sim 10$ microtubular ducts; ventral lobe seta $15-25 \mu \mathrm{m}$, dorsolateral 
lobe seta $27-35 \mu \mathrm{m}$, dorsomedial lobe seta $55-62 \mu \mathrm{m}$, dorsoapical seta $59-75 \mu \mathrm{m}$, caudal seta $37-45 \mu \mathrm{m}$.

Dorsum. Derm uniformly membranous. Dorsal setae spinose, bases swollen, apices blunt to truncate, each seta 35-80 $\mu \mathrm{m}$ long; arranged in a transverse row across each abdominal segment, number of setae in each row increasing cephalad from a single pair on segment VIII to $\sim 10$ on segment I, setae scattered over head and thorax. Margin delineated by staggered setae similar to those on dorsum, each seta $35-85 \mu \mathrm{m}$ long; larger, more ventral setae alternating with smaller, more dorsal setae. Macrotubular ducts absent. Microtubular ducts 5-8 $\mu \mathrm{m}$ long, scattered over dorsum; 1-4 opening at base of most enlarged setae.

Venter. Flagellate setae 12-32 $\mu \mathrm{m}$ long, in a transverse row across medial portion of each abdominal segment; submarginal area naked; longitudinal series of short setae, each 5-8 $\mu \mathrm{m}$ long,

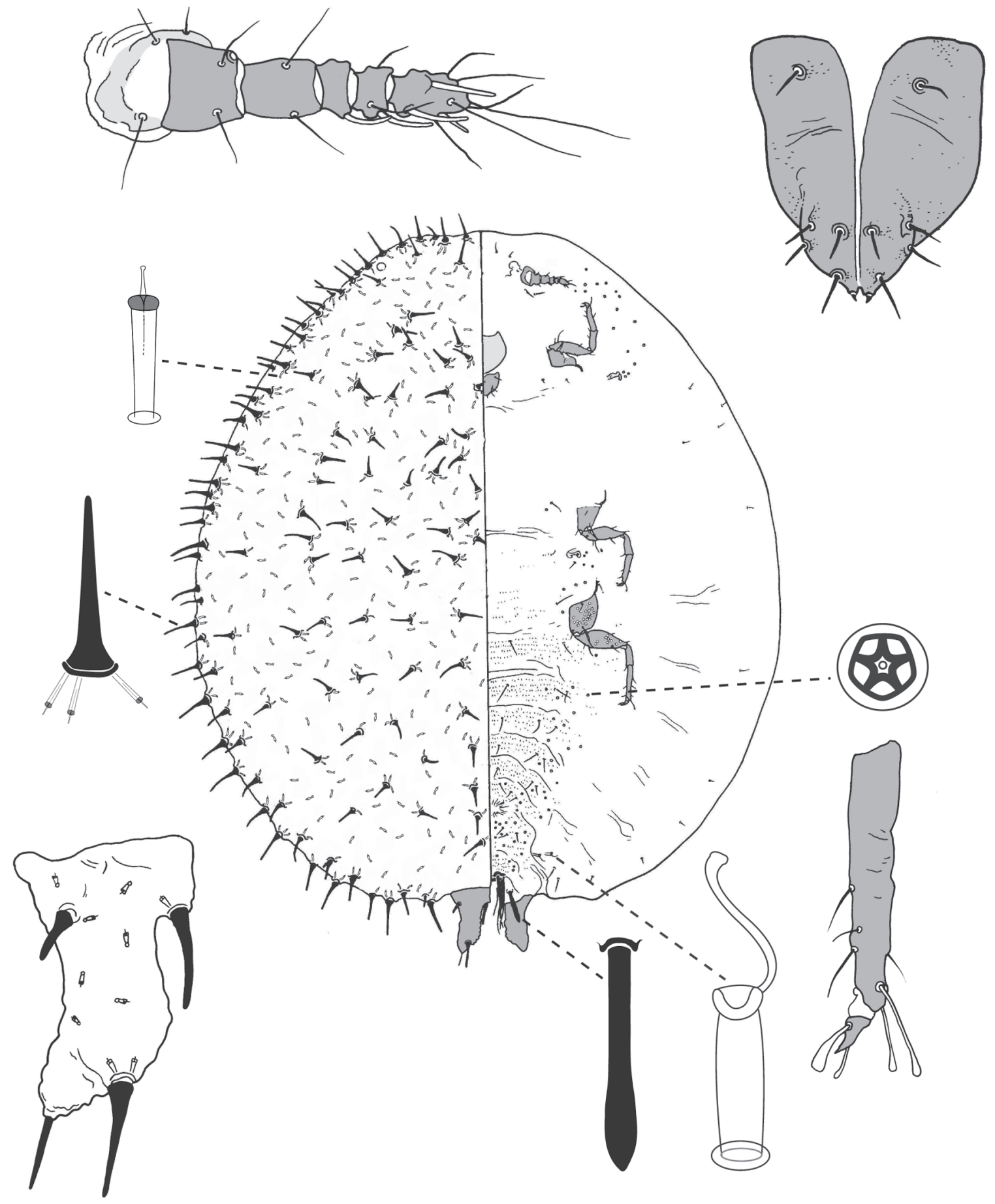

Fig. 5. Adult female of Madarococcus cunninghamii, sp. nov. 
just ventrad of marginal fringe; setae medial of coxae 30-45 $\mu \mathrm{m}$ long; setae on head posteromedial of antennal insertions 32-45 $\mu \mathrm{m}$ long. Macrotubular ducts $13-15 \mu \mathrm{m}$ long, only two pairs, posterolateral of vulva. Microtubular ducts absent. Quinquelocular pores $4 \mu \mathrm{m}$ in diameter, clustered in submedial band extending from anal ring to posterior spiracles, then continuing from anterior spiracles to bases of antennae, pores absent from space between anterior and posterior spiracles (except possibly for pores near long setae anteromedial of mid coxae).

\section{Diagnostic features}

Madarococcus cunninghamii would be most easily confused with M. pulchellus or M. viridulus. In life, the adult females of all three species are light green and extrude glassy filaments from enlarged dorsal setae (Fig. $4 C, L$ ). The slide-mounted adult females of these three species are similar in lacking macrotubular ducts on the dorsum, and having only enlarged dorsal setae. Madarococcus cunninghamii can be recognised by having 1, macrotubular ducts present posterolateral of the vulva; 2 , apical lobe seta shorter than dorsoapical lobe seta, and 3, a 2-segmented labium.

\section{First-instar nymph (Fig. 6)}

Mounted material. Body length 300-342 $\mu \mathrm{m}$, greatest width 145-235 $\mu \mathrm{m}$. Eyespot on margin, $8-10 \mu \mathrm{m}$ wide. Antennae 6-segmented, 69-73 $\mu \mathrm{m}$ long; with three hair-like setae (trichoid sensilla) on segment I, one hair-like seta on II, two hair-like setae on III, one fleshy seta on IV, three hair-like setae and one fleshy seta on $\mathrm{V}$, and $\sim 6$ hair-like setae plus three fleshy setae on VI. Tentorial box 57-62 $\mu \mathrm{m}$ long, 49-60 $\mu \mathrm{m}$ wide. Labium composed of two fused segments, c. $30 \mu \mathrm{m}$ long, 32-40 $\mu \mathrm{m}$ wide; with five pairs of setae on anterior surface, one pair of short apical setae, and one pair of setae on posterior surface. Spiracles $10-12 \mu \mathrm{m}$ long, $5 \mu \mathrm{m}$ wide across atrium. All legs more or less same size; coxa 12-16 $\mu \mathrm{m}$, trochanter + femur 52-56 $\mu \mathrm{m}$, tibia $22-27 \mu \mathrm{m}$, tarsus $30-37 \mu \mathrm{m}$, claw 9-11 $\mu \mathrm{m}$; tarsal digitules unequal $12-20 \mu \mathrm{m}$; claw digitules $10-13 \mu \mathrm{m}$ long, asymmetrical, one with terminal knob $2 \mu \mathrm{m}$ wide, the other with terminal knob $1 \mu \mathrm{m}$ wide. Anal ring 18-21 $\mu \mathrm{m}$ wide, bearing six setae, 35-40 $\mu \mathrm{m}$ long. Suranal setae spatulate, 24-26 $\mu \mathrm{m}$ long, arising from small pad of sclerotic cuticle. Anal lobes subconic, $25-27 \mu \mathrm{m}$ long, inner margin crenulate; ventral lobe seta 11-14 $\mu \mathrm{m}$, dorsolateral lobe seta $7-9 \mu \mathrm{m}$, dorsomedial lobe seta $9-11 \mu \mathrm{m}$, dorsoapical lobe seta $27-33 \mu \mathrm{m}$, caudal seta 23-35 $\mu \mathrm{m}$.

Dorsum dominated by three pairs of greatly enlarged, spinose setae, arising from submedial portion of metathorax, prothorax and anterior margin of head (these setae of same size and shape as those on dorsum of adult females); each seta 27-54 $\mu \mathrm{m}$ long, with blunt apex and swollen base; short (each $2 \mu \mathrm{m}$ long), blunt-tipped setae in two longitudinal rows on each side of body: one medial series on each side of body running from abdominal segment VII to metathorax, and one submedial series on each side of body extending from anterior abdominal segments to prothorax. Margin with distinct fringe of setae, each seta 15-20 $\mu \mathrm{m}$ long, similar to enlarged dorsal setae, with one seta on each side of each abdominal segment, two setae on each side of both metathorax and mesothorax, five setae on each side of both prothorax and head. Macrotubular ducts absent. Microtubular ducts 5-8 $\mu \mathrm{m}$ long, one anterior to each anal lobe, others associated with about half of marginal fringe setae and with each enlarged dorsal seta.

Venter with setae in three longitudinal rows on each side of abdomen, one marginal and one submarginal row on each side of body extending onto mesothorax; each seta 3-10 $\mu \mathrm{m}$ long, setae medial of coxae difficult to detect, 10-15 $\mu \mathrm{m}$ long; three pairs of setae on head between antennal insertion points, each seta 11-32 $\mu \mathrm{m}$ long. Macrotubular ducts and microtubular ducts absent. Trilocular pores arranged in a single longitudinal row on each side of abdomen, between medial and submarginal rows of setae; one near each posterior spiracle, two near each anterior spiracle, pores medial of coxae not detected.

\section{Diagnostic features}

The three pairs of enlarged dorsal setae are unique amongst the first-instar nymphs of known eriococcids on Nothofagus.

\section{Remarks}

Despite the superficial similarity between the adult females of $M$. cunninghamii and those of the New Zealand species $M$. viridulus and $M$. pulchellus, the sequence data strongly support $(\mathrm{PP}=1.0)$ a sister-group relationship between $M$. cunninghamii and the Australian species M. moorei, sp. nov.

\section{Etymology}

This species is named for its host $N$. cunninghamii.

Madarococcus detectus (Hoy), comb. nov.

Eriococcus detectus Hoy, 1962a: 70-71, fig. 21. Type data: New Zealand: South Island, Christchurch, on N. solandri var. solandri, 16.xii.1915, G. Brittin. Holotype and five paratype females, by original designation. Type depository: NZAC.

Acanthococcus detectus; Miller \& Gimpel, 1996: 600. Change of combination.

\section{Remarks}

Hoy (1962a) erroneously described the adult female of $M$. detectus as having dorsal macrotubular ducts, but macrotubular ducts are confined to marginal and submarginal zones of the venter. Madarococcus detectus appears to be most closely related to M. montifagi, with both species having a rotund body shape, lacking dorsal macrotubular ducts and having a conspicuous pit near the anterior margin of the dorsal surface of each anal lobe. Madarococcus detectus is easily distinguished from M. montifagi by having several enlarged dorsal setae (M. montifagi has only minute setae on the dorsum).

Madarococcus eurythrix (Miller \& González), comb. nov.

Eriococcus eurythrix Miller \& González, 1975: 142-144, Fig. 5. Type data: Chile: near Villa Portales, on Nothofagus antarctica, 25.xi.1968, R. González. Holotype and 26 paratype females, by original designation. Type depositories: Holotype: MEUC; Paratypes: BMNH, NZAC, MNHM, BME, USNM (including VIP), ZIN.

Acanthococcus eurythrix; Miller \& Gimpel, 1996: 600. Change of combination. 


\section{Material examined}

Chile: IX Region, Villarrica, leaves of N. alpina (ANIC, BME); same data as previous but leaf of N. obliqua (ANIC); X Region, Hotel Peulla, ex leaves of $N$. obliqua (BME).

\section{Remarks}

We have examined specimens from four locations in Chile on N. alpina, N. antarctica and N. obliqua. Madarococcus eurythrix bears several morphological similarities with the Chilean species $M$. chilensis, $M$. navarinoensis, and $M$. rhadinothrix: 1 , slender, slightly curved dorsal setae; 2, a loose marginal fringe of enlarged setae, most distinct on posterior abdominal segments, becoming staggered on thorax and head, and 3, dorsal setae without associated microtubular ducts. Madarococcus eurythrix also shares some key features with the Australasian Madarococcus species: 1, spatulate suranal setae; 2 , interantennal lobes; 3 , ventral macrotubular ducts of a single size, similar to those on dorsum, and 4, disc pores of a single size (two sizes of disc pores are found on the ventral surfaces of E. chilensis, E. navarinoensis and M. rhadinothrix). Madarococcus eurythrix

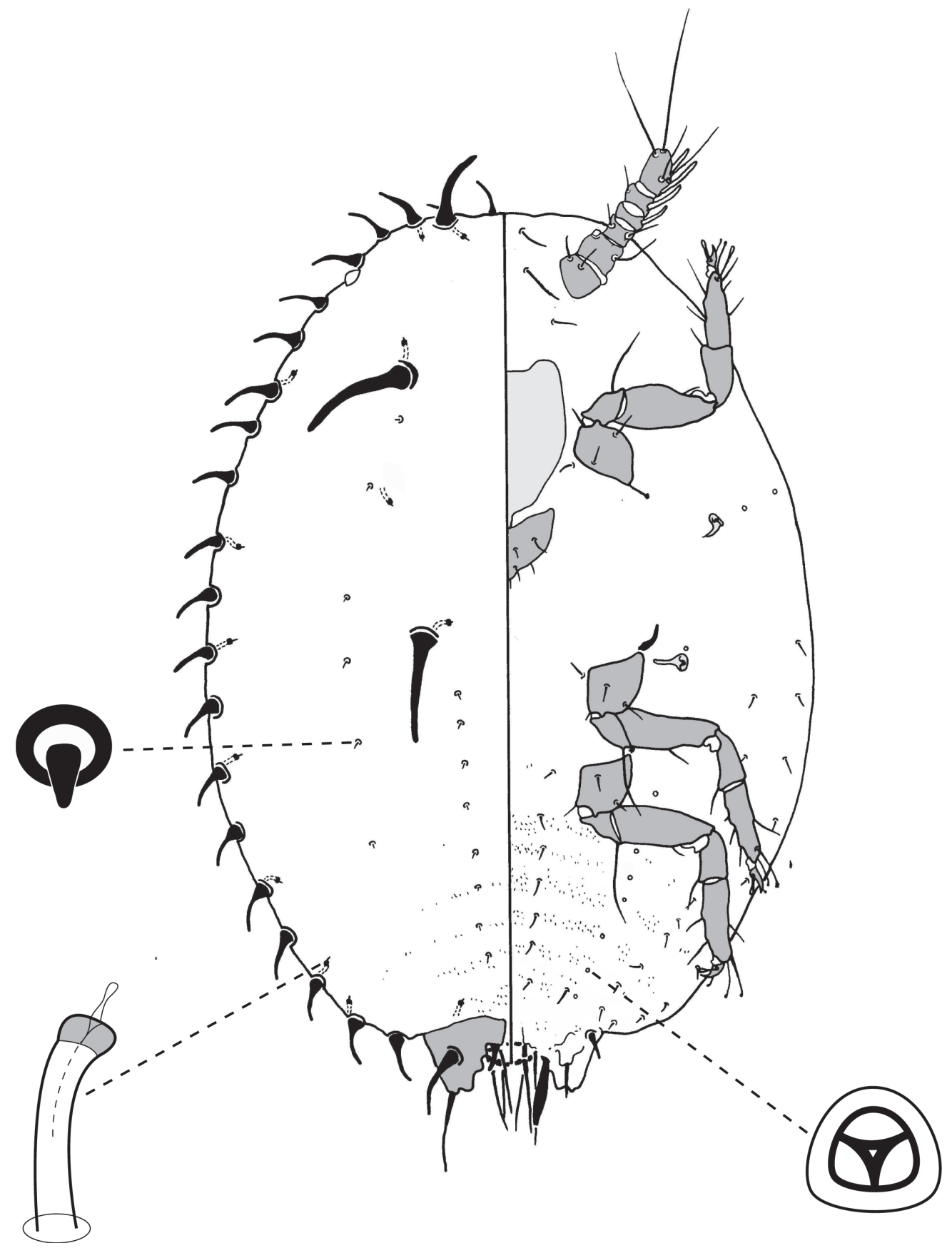

Fig. 6. First-instar nymph of Madarococcus cunninghamii, sp. nov. 
most closely resembles the Tasmanian species $M$. occultus, sp. nov. Characteristics shared by these two species include 1 , the shape and distribution of the dorsal and marginal setae; 2, anal lobes small in comparison to those of other Madarococcus species, and 3, macrotubular ducts present on the medial portions of each abdominal segment. In our analysis of the sequence data, we found weak support $(\mathrm{PP}=0.87$ ) for a clade comprised of $M$. eurythrix along with two other Chilean Madarococcus populations, M. navarinoensis and M. nr navarinoensis.

Madarococcus fagicorticis (Maskell), comb. nov.

Eriococcus fagicorticis Maskell, 1892: 27, pl. V, figs 1-5. - Hoy, 1962a: 76, fig. 24. Type data: New Zealand: South Island, Reefton district, on N. fusca (as Fagus fusca). Lectotype female, by subsequent designation of Deitz \& Tocker, 1980: 46. Type depository: NZAC. Nidularia fagicorticis; Lindinger, 1933: 108. Change of combination.

Acanthococcus fagicorticis; Miller \& Gimpel, 1996: 600. Change of combination.

\section{Remarks}

Hoy (1962a) illustrated and redescribed the adult female of this species. Miller and Gimpel (2000) incorrectly list York Bay as part of the type data. In his list of specimens examined, Hoy (1962a) clearly states that one specimen from York Bay was collected by D. Miller in 1922; thus it is not part of the type series. Unfortunately the lectotype female of this species was lost during curatorial remounting. There is some probable paralectotype material in the NZAC: 1 , a slide with one adult female and the data: 'Eriococcus fagicorticis / Maskell spare material / X Nothofagus / June 1939' [date of Brittin's slide-mount] and 2, a Maskell original of a neonate 1st-instar nymph labelled: 'Eriococcus fagicorticis / larva/ 1890 / W.M.M.'. We have examined a single specimen from York Bay. It is in poor condition, but appears to match Hoy's (1962a) illustration. An additional three adult females, on one slide held in the NZAC with the data 'Lichen on Nothofagus sp. / Lake Sylvester / Nelson / 29.iv.69 / J. E. Tobler,' are in good condition and closely match Hoy's drawing and description. Thus there is no doubt as to the identity of the species. Maskell (1892) observed that adult females occurred in bark crevices of $N$. fusca, accompanied by a great deal of sooty mould. Madarococcus fagicorticis is the only species of Madarococcus for which the adult female both produces a test and has a distinct marginal fringe of enlarged setae. The combination of dorsal macrotubular ducts and a marginal fringe make this species easy to distinguish from all other Australasian species.

Madarococcus hispidus (Hoy), comb. nov.

Eriococcus hispidus Hoy, 1962a: 30, 86-87, fig. 29. Type data: New Zealand: North Island, Ohakune, on $N$. solandri var. cliffortioides, 10.ii.1960, J. M. Hoy. Holotype female, by original designation. Type depository: NZAC.

Acanthococcus hispidus; Miller \& Gimpel, 1996: 601. Change of combination.

Material examined

New Zealand: BP, Te Koau, N. solandri (NZAC); BP, East Cape, Rereauira Swamp, Beech Ridge, N. truncata (NZAC); GB, Kakanui N. truncata (NZAC).
Remarks

Madarococcus hispidus is most similar to M. cavellii [see comments under $M$. cavellii].

Madarococcus intermedius (Maskell), comb. nov.

(Fig. 4D)

Rhizococcus intermedius Maskell, 1891: 19-20, pl. V, Figs 8-11. Type data: New Zealand: South Island, Reefton, on N. menziesii (as Fagus menziesii), iii.1890, W. M. Maskell. Lectotype female, by subsequent designation of Deitz \& Tocker, 1980: 47. Type depository: NZAC (see below).

Nidularia intermedius; Lindinger, 1933: 116. Change of combination.

Sisyrococcus intermedius; Hoy, 1962a: 182-183, fig. 73. Change of combination.

\section{Material examined}

New Zealand: WO, Hamilton Gardens, leaf buds/stunted or aborted shoots of N. menziesii (NZAC); TO, Ohakune, Moore St, leaf axils of N. menziesii (ANIC); BR, Mai Mai Valley Rd, buds and leaf axils of $N$. menziesii (ANIC); WD, Haast Valley, Pleasant Flat, buds of N. menziesii (ANIC).

\section{Remarks}

Hoy (1962a) transferred this species as the type of his new genus Sisyrococcus, and illustrated and redescribed the adult female. In addition to the lectotype, the NZAC has 1, three original slides: one labelled 'larva'; one labelled 'female 2nd-stage' [actually an adult female]; one labelled ' 2 males', and 2, 16 slides mounted by Hoy, 14 labelled 'Mask Coll. / Ex Nothofagus menziesii leaf axils / 1890 [no coll no.],' and two with same data except for a more specific date, March 1890. In addition, Deitz and Tocker (1980) refer to three subsequent slides in the USNM and the entry for this species in ScaleNet (Ben-Dov et al. 2007) and the recent world catalogue of Eriococcidae (Miller and Gimpel 2000) refers to 'Type material also in USNM'. Apparently there is only one USNM slide labelled as 'Rhizococcus intermedius Maskell, New Zealand, Maskell Collection \# 124.' (D. R. Miller personal communication). There are no specimens with the number 124 in the Maskell collection in the NZAC and the type status of the USNM specimen is uncertain.

Hoy's two species of Sisyrococcus, now M. intermedius and M. papillosus, have very unusual adult females. In mature specimens (Fig. $4 D$ ), the dorsal surface of the anterior abdominal segments is folded back and over the posterior segments, concealing the anal lobes from the dorsal aspect. Macrotubular ducts are found only on the dorsal surface of the abdomen and, on the anterior segments, they are arranged in tight, transverse rows. Madarococcus intermedius can be distinguished from M. papillosus by having far fewer dorsal setae, and all but a few pairs confined to the margin (in M. papillosus the dorsum is covered with $c .500$ setae and the margin is indistinguishable). Madarococcus intermedius is unique among Madarococcus species in having quinquelocular disc pores on the dorsum, in a narrow medial band on the head. The suranal setae on M. intermedius and M. papillosus often appear non-spatulate, and in young adult females they can have fine flagellate tips that later break off. 
In life, young females of $M$. intermedius are pinkish-brown to pale yellow, whereas adult females are orange-yellow to orange-brown or sometimes reddish or greenish, with short, glassy marginal wax filaments (each emanating from a marginal seta) and a scattering of white wax specks on the dorsum. Mature females shelter embryos in a cavity under their body. Tests of males are creamy white and occur on the undersides of leaves, especially near the leaf margins.

Madarococcus latilobatus (Hoy), comb. nov.

Eriococcus latilobatus Hoy, 1962a: 31, 94-95, fig. 33. Type data: New Zealand: South Island, Lake Wakatipu, Lumberbox Creek, on N. solandri var. cliffortioides, 15.xi.1958, J. M. Hoy. Holotype and five paratype females, by original designation. Type depository: NZAC.

Acanthococcus latilobatus; Miller \& Gimpel, 1996: 601. Change of combination.

Remarks

The adult females of $M$. latilobatus most closely resemble those of $M$. rotundus. Hoy (1962a) separated them by counting enlarged dorsal setae: 10-20 on the head and thorax of M. latilobatus as opposed to four or fewer located on the thorax of $M$. rotundus. He acknowledges the plasticity of the feature in $M$. rotundus; in many specimens the enlarged setae are completely absent. Setal number may be variable within some species, for example, there is drastic variation in the number of dorsal enlarged setae amongst individuals of $M$. moorei, sp. nov. both within and among separate collections. Perhaps M. latilobatus and $M$. rotundus are the same species, but we have insufficient material to investigate this possibility.

\section{Madarococcus maculatus (Maskell)}

Rhizococcus maculatus Maskell, 1890: 144-145, pl. VII, figs 6-12. Type data: New Zealand: South Island, Reefton district, on N. solandri var. cliffortioides (as Fagus cliffortioides), W. M. Maskell. Lectotype female, by subsequent designation of Deitz \& Tocker, 1980: 47. Type depositories: NZAC, USNM (see below).

Nidularia maculatus; Lindinger, 1933: 116. Change of combination.

Madarococcus maculatus; Hoy, 1962a: 6, 7, 151, 156-157, fig. 63. Change of combination.

Material examined

New Zealand: BP, East Cape, Rereauira Swamp, Beech Ridge, N. truncata (NZAC); NN, Harwoods Hole, N. fusca, females without a sac (NZAC); BR, Springs Junction, Palmer Road, $N$. fusca, females without a test (NZAC).

Remarks

Hoy (1962a) illustrated and redescribed the adult female of this species and provided $N$. fusca as an additional host record based on a collection from Ohakune. Although Hoy admits that his description of the adult female conflicts with that of Maskell (1890), he based it on the only available material identified by Maskell as Rhizococcus maculatus. Maskell's label on the lectotype female is 'Rhizococcus maculatus / female - 2nd stage / on Fagus sp. / Sept. 1889 W.M.M.' but this female is adult as indicated by Hoy's subsequent label: 'Madarococcus maculatus / adult female / det. J. M. Hoy 1961'. Another Maskell slide sim- ilarly labelled as 'early 2 nd stage' is not $M$. maculatus and a third Maskell slide with this species name has four first-instar nymphs. If the second-instar described by Maskell was, in fact, an adult, his and Hoy's description differ only in the number of antennal segments (six according to Maskell $v$. seven according to Hoy). More conflict arises when Hoy's description is compared to Maskell's description of the adult female, in which Maskell asserts that no dorsal spines are present, whereas Hoy counts $c$. 28. Perhaps the 'adult' of Maskell was an older specimen in which the dorsal setae had been damaged or lost.

There is some probable paralectotype material in the USNM but the status of Maskell material sent to the USA is uncertain. The one slide-mounted USNM specimen, with Maskell No. 112, was mounted subsequently (not by Maskell) but may have been part of the series that Maskell used to describe the species; the Cockerell Collection in the USNM also has dry material identified as this species, with Maskell No. 56 (D. R. Miller personal communication). There is no Maskell material in the NZAC with the numbers 56 or 112.

The adult females of $M$. maculatus are most similar to those of M. cruriamplus. Features shared between the two are: 1, macrotubular ducts absent; 2 , enlarged dorsal setae few or absent; 3, distinct marginal fringe present, and 4, suranal setae approximately as long as anal lobes. The adult females of M. maculatus differ from those of M. cruriamplus by having numerous enlarged dorsal setae (all dorsal setae minute in M. cruriamplus).

\section{Madarococcus maskelli (Hoy), comb. nov.}

(Fig. 4E)

Eriococcus maskelli Hoy, 1962a: 98-99, fig. 35. Type data: New Zealand, on $N$. solandri var. cliffortioides. Holotype and five paratype females, by original designation. Type depository: NZAC. Acanthococcus maskelli; Miller \& Gimpel, 1996: 602. Change of combination.

\section{Material examined}

New Zealand: NN, Inwoods Lookout, $N$. menziesii, underside leaves, in tawny tests (NZAC); MC, Lake Pearson, State Highway 73, forest by roadside, N. solandri underside leaves (NZAC); FD, Lake Manapouri, Spey River flats, $N$. menziesii (NZAC).

\section{Remarks}

No type data, other than the country and host plant, are available. The type specimens came from Maskell's duplicate material and were labelled as Eriococcus raithbyi (Hoy, 1962a). Madarococcus maskelli is very similar to M. podocarpi. Both species have dorsal nodules with acute apices, a feature unique among species of Madarococcus except M. fagicorticis. A distinction between the two species can be made on the basis of the dorsal setae on the posterior abdominal segments. In M. maskelli all dorsal setae are approximately the same size, and the submedial areas on each side of each of segments VI and VII are occupied by one or more setae. In M. podocarpi, abdominal segments VI and VII have the medial pairs of setae much smaller than those on the rest of the dorsum, and the submedial areas are without setae. The medial setae on last three abdominal segments of the type specimens of E. maskelli are 18-25 $\mu \mathrm{m}$ 
long, whereas the same setae on the holotype of E. podocarpi are 3-5 $\mu \mathrm{m}$ long. Also, adult females of $M$. maskelli usually have more translucent pores on the hind coxa and femur than females of $M$. podocarpi, but this variation needs to be verified in a larger sample of specimens.

Recent collections of adult females of $M$. maskelli on $N$. solandri (MC, Lake Pearson, \#05-167, 5 females) match the types in that the medial dorsal setae on the last three abdominal segments are about the same size as those on the head, whereas the medial dorsal setae on the last three abdominal segments are smaller than those on the head on three specimens from N. menziesii (NN, Inwoods Lookout, and FD, Lake Manapouri).

Madarococcus meander Hardy \& Gullan, sp. nov.

$$
\text { (Figs } 4 F, 7,8 \text { ) }
$$

\section{Material examined}

Holotype. Tasmania: 1 adult female: Meander Forest Reserve, Mother Cummings Creek, ex pit gall on under leaf of N. cunninghamii, 12.xi.1999, PJG (ANIC).

Paratypes. Tasmania: 4 adult females and c. 30 first-instar nymphs (three slides): same data as holotype (six slides ANIC, one slide TASAG); 1 adult female: Meander State Forest, 19.ii.2004, ex pit gall on leaf of N. cunninghamii, L. G. Cook \& M. D. Crisp (ANIC); 4 adult females:

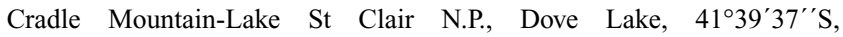
$145^{\circ} 57^{\prime} 27^{\prime \prime} \mathrm{E}, 950 \mathrm{~m}$, ex pit galls on leaves of N. cunninghamii, 25.i.2006, PJG (two slides ANIC, two slides TASAG); 1 adult female: Mt Field N.P., $42^{\circ} 40^{\prime} 17^{\prime \prime} \mathrm{S}, 146^{\circ} 40^{\prime} 50^{\prime \prime} \mathrm{E}$, ex pit gall on leaf of $N$. cunninghamii, 23.i.2006, PJG (ANIC); 4 adult females: near Strahan, on N. cunninghamii, 28.vi.1972, J. W. Beardsley (BPBM); 4 adult females: $10 \mathrm{~km} \mathrm{SSE} \mathrm{of}$ Weldborough, $41^{\circ} 13^{\prime} \mathrm{S}, 147^{\circ} 56^{\prime} \mathrm{E}$, ex pit galls on underside of leaves of N. cunninghamii, 26.i.2006, PJG (three slides ANIC, one slide USNM). Victoria: 11 adult females (seven slides): 8 miles [13 km] E of Marysville, in small pit or leaf pocket galls on leaves of N. cunninghamii, 19.x.1971, J. W. Beardsley, V-134 (BPBM); 3 adult females (one slide): Otway Ranges, 27.x.1972, ex pit galls in leaves of N. cunninghamii, J. W. Beardsley, V-162 (BPBM).

\section{Description}

\section{Adult female (Fig. 7)}

Live material. The female of $M$. meander induces a small pit gall on the leaves of $N$. cunninghamii (Fig. $4 F$ ). The body of the female fills the leaf pit, with the female's dorsum lying level with the top of the pit and becoming more sclerotized with age. White wax is extruded from between the anal lobes and around the margin of the body. The colour of the live female is yellowbrown, becoming darker with age. The female is ovoviviparous and newly emerged crawlers do not shelter under female's body before dispersing.

Mounted material. Body outline ovate, length 0.88-1.28 $\mathrm{mm}$ (holotype $1.26 \mathrm{~mm}$ ), greatest width $0.70-1.14 \mathrm{~mm}$ (holotype $0.94 \mathrm{~mm}$ ), venter slightly larger than dorsum in more fully expanded specimens. Eyespot $15-17 \mu \mathrm{m}$ wide, ventrad of margin. Antennae 6-segmented; length 85-102 $\mu \mathrm{m}$; with four hair-like setae (trichoid sensilla) on segment I, 2-3 hair-like seta on II, two hair-like setae on III, one fleshy seta on IV, 3-4 hairlike setae plus one fleshy seta on $\mathrm{V}$, and seven hair-like seta plus three fleshy seta on VI. Frontal (interantennal) lobes not detected. Tentorial box 75-85 $\mu \mathrm{m}$ long, $70-75 \mu \mathrm{m}$ wide. Labium
50-80 $\mu \mathrm{m}$ long, 42-50 $\mu \mathrm{m}$ wide; 3-segmented; seven pairs of seta on anterior surface, one apical pair of short setae, one pair of seta on posterior surface. Spiracles 20-25 $\mu \mathrm{m}$ long, $10 \mu \mathrm{m}$ wide across atrium. Legs subequal (except hind tarsi that are 5-11 $\mu \mathrm{m}$ longer than mid tarsi or fore tarsi); coxa $22-35 \mu \mathrm{m}$, trochanter + femur 70-87 $\mu \mathrm{m}$, tibia $32-42 \mu \mathrm{m}$, tarsus $45-62 \mu \mathrm{m}$, claw $15 \mu \mathrm{m}$; coxa with six setae, trochanter with four setae (longest seta 30-40 $\mu \mathrm{m}$ ), fore femur with six setae, mid femur and hind femur each with five setae, tibia with four setae, tarsus with six setae; tarsal digitules $22-27 \mu \mathrm{m}$ long, claw digitules dissimilar, 15-20 $\mu \mathrm{m}$ long, one with apical knob $4 \mu \mathrm{m}$ wide, other with apical knob $1 \mu \mathrm{m}$ wide; hind coxa with $c .15$ translucent pores on dorsolateral surface. Anal ring 30-35 $\mu \mathrm{m}$ wide, bearing six setae, $60-75 \mu \mathrm{m}$ long. Suranal setae spatulate, $17-20 \mu \mathrm{m}$ long. Anal lobes 47-61 $\mu \mathrm{m}$ long, with inner margin parallel to longitudinal body-axis, each lobe with one microtubular duct; ventral lobe seta 13-17 $\mu \mathrm{m}$ long, spatulate, dorsolateral lobe seta $26-33 \mu \mathrm{m}$, dorsomedial lobe seta $26-38 \mu \mathrm{m}$, dorsoapical lobe seta $29-39 \mu \mathrm{m}$, caudal seta $70-71 \mu \mathrm{m}$.

Dorsum. Derm sclerotic. Dorsal setae 1-7 $\mu \mathrm{m}$ long, squat, spinose; one medial pair on each segment except prothorax with two pairs, and abdominal segment VIII with no setae; one submedial seta on each side of abdominal segment I and head; 2-3 setae in transverse row extending laterad of each medial seta on thoracic segments. Margin delineated by fringe of slightly curved setae, 18-37 $\mu \mathrm{m}$ long; one seta on each side of abdominal segments II-VII, two setae on each side of abdominal segment I, three setae on each side of metathorax and three setae on each side of mesothorax, continuous series of $\sim 11$ setae on each side of prothorax and head, fringe deflected dorsad over eyes. Macrotubular ducts 10-12 $\mu \mathrm{m}$ long, in marginal series. Microtubular ducts $\sim 5 \mu \mathrm{m}$ long, a single medial duct on abdominal segment VIII.

Venter. Flagellate setae 6-15 $\mu \mathrm{m}$ long, in a transverse row across each abdominal segment; setae medial of coxae 8-20 $\mu \mathrm{m}$ long, setae on head between antennae 11-35 $\mu \mathrm{m}$ long. Macrotubular ducts absent. Microtubular ducts confined to submargin of posterior abdominal segments, one duct on each side of abdominal segments V-VII. Quinquelocular pores $3 \mu \mathrm{m}$ in diameter, scarce; in linear series running from anal lobes to posterior spiracles, clustered around anterior and posterior spiracles, 1-2 medial of each coxa.

\section{Diagnostic features}

Madarococcus meander is most similar to the other gallinducing Madarococcus species, M. cunicularius and M. megaventris, sp. nov. All three species have 1, 6-segmented antennae; 2, a sclerotic dorsum; 3 , relatively few dorsal setae; 4 , an expanded venter, and 5 , no ventral tubular ducts. Adult females of M. meander and M. cunicularius can be distinguished from those of M. megaventris, sp. nov. by having 1 , spatulate suranal setae (evenly attenuated in M. megaventris, sp. nov.); 2 , ventral lobe seta arising proximal of caudal seta (arising distal of apical seta in M. megaventris, sp. nov.); 3, relatively few dorsal tubular ducts (numerous in M. megaventris, sp. nov.), and 4, venter only moderately expanded (extremely expanded in $M$. megaventris, sp. nov.). Adult females of $M$. meander can be distinguished from adult females of $M$. cunicularius by having 1 , macrotubular ducts along the margin (in M. cunicularius macrotubular ducts are 
completely absent); 2 , far fewer disc pores on the ventral surface of the abdomen (only a sparse submedial line as opposed to a broad submedial longitudinal band), and 3, a distinctive anal lobe shape: truncate apex and straight inner margin parallel to the longitudinal body-axis (the anal lobes of M. cunicularius are subconical and have rounded apices).

\section{First-instar nymph (Fig. 8)}

Mounted material. Body length 300-415 $\mu \mathrm{m}$, greatest width 127-220 $\mu \mathrm{m}$. Eyespot 9-11 $\mu \mathrm{m}$ wide, on margin. Antennae 6-segmented, 56-68 $\mu \mathrm{m}$ long; with three hair-like setae (trichoid sensilla) on segment I, two hair-like setae on II, two hair-like seta on III, one fleshy seta on IV, three hair-like

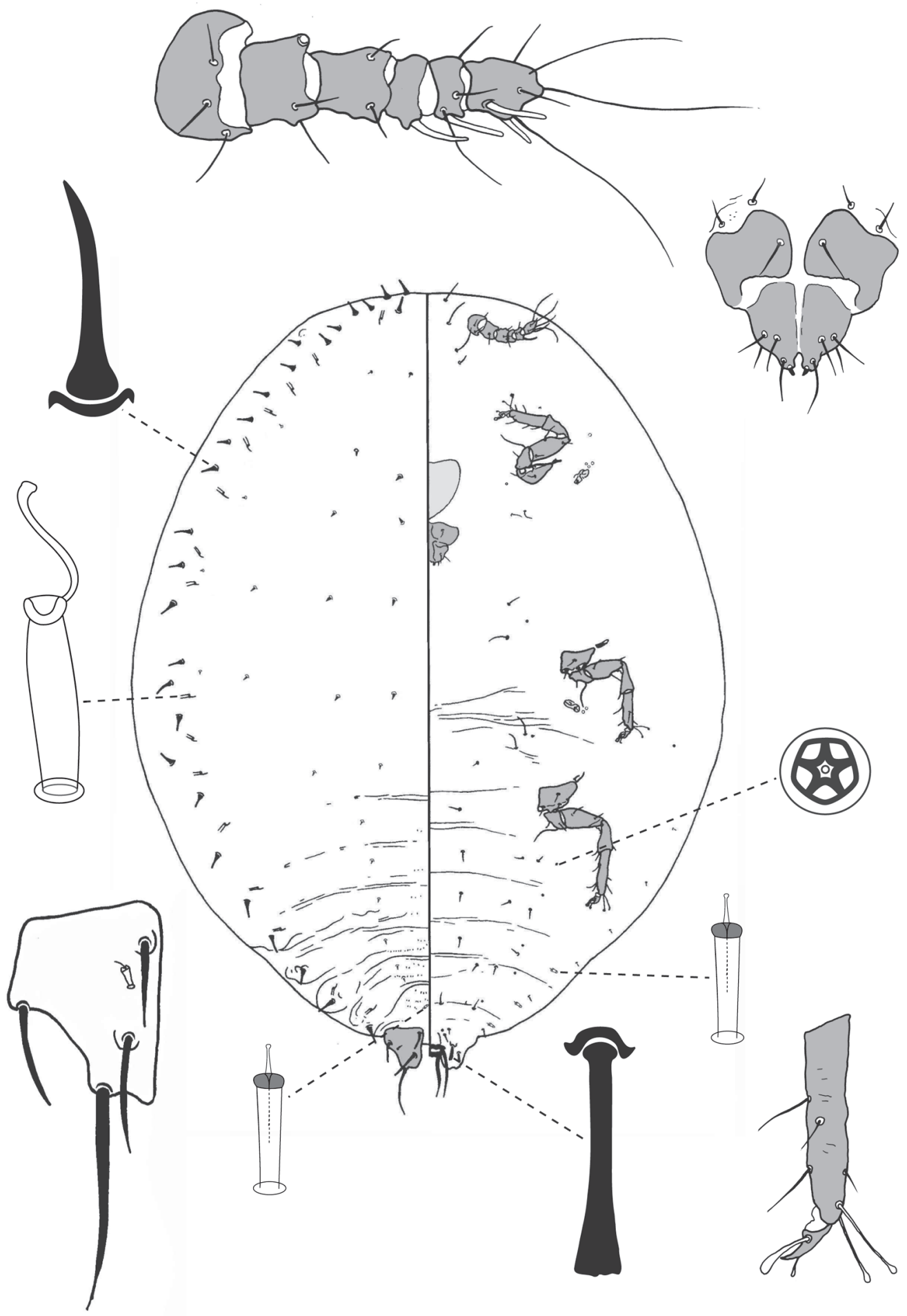

Fig. 7. Adult female of Madarococcus meander, sp. nov. 
setae plus one fleshy seta on $\mathrm{V}$, and seven hair-like setae plus three fleshy seta on VI. Tentorial box 52-60 $\mu \mathrm{m}$ long, 50-58 $\mu \mathrm{m}$ wide. Labium 3-segmented, 27-36 $\mu \mathrm{m}$ long, 30-38 $\mu \mathrm{m}$ wide; seven pairs of setae on anterior surface, one apical pair of short setae, one pair of setae on posterior surface. Spiracles 12-16 $\mu \mathrm{m}$ long, 5-6 $\mu \mathrm{m}$ wide across atrium. Legs subequal; coxa 12-17 $\mu \mathrm{m}$, trochanter + femur $47-51 \mu \mathrm{m}$, tibia $18-27 \mu \mathrm{m}$, tarsus 27-38 $\mu \mathrm{m}$, claw $10-12 \mu \mathrm{m}$; tarsal digitules $15-19 \mu \mathrm{m}$ long, claw digitules $10-13 \mu \mathrm{m}$ long, one more robust than other. Anal ring $20 \mu \mathrm{m}$ wide, bearing six setae, 31-38 $\mu \mathrm{m}$ long. Suranal setae spatulate, $13-15 \mu \mathrm{m}$ long. Anal lobes $22-32 \mu \mathrm{m}$ long, subconic; ventral lobe seta spatulate, $10-13 \mu \mathrm{m}$ long, dorsolateral lobe seta 9-12 $\mu \mathrm{m}$, dorsomedial lobe seta $14-17 \mu \mathrm{m}$, dorsoapical lobe seta $19-21 \mu \mathrm{m}$, apical seta $37-50 \mu \mathrm{m}$.

Dorsum. Derm faintly nodulose. Dorsal setae of two types: 1 , minute subdigitate setae, $2-3 \mu \mathrm{m}$ long, in a medial series on each side of abdominal segments II-VII; 2, enlarged setae, 5-17 $\mu \mathrm{m}$ long, with swollen bases and blunt to truncate apices, extending medial series with one seta on each side of abdominal segment I, metathorax and mesothorax, two setae on each side of prothorax, and one seta on each side of head, one seta laterad of each medial seta on metathorax and mesothorax, plus one laterad of each anterior medial seta on prothorax, setation of abdominal segment I unstable, setae may be either subdigitate or enlarged. Margin with fringe of setae similar to enlarged dorsal setae, 6-13 $\mu \mathrm{m}$ long; one seta on each side of abdominal segments I-VII, two setae on each side of metathorax and mesothorax, four setae on each side of prothorax and 8-12 setae on head between eyes. Macrotubular ducts absent. Microtubular ducts in marginal series from head to abdominal segment VIII, plus one microtubular duct laterad of each medial seta on head and thorax. Disc pores absent.

Venter with flagellate setae 4-11 $\mu \mathrm{m}$ long, in four longitudinal rows on each side of abdomen, with marginal row extending through thorax and onto head; setae medial of coxae not detected, three pairs of setae on head, 12-20 $\mu \mathrm{m}$ long. Macrotubular ducts and microtubular ducts absent. Disc pores trilocular, $3 \mu \mathrm{m}$ in diameter; in submedial series on either side

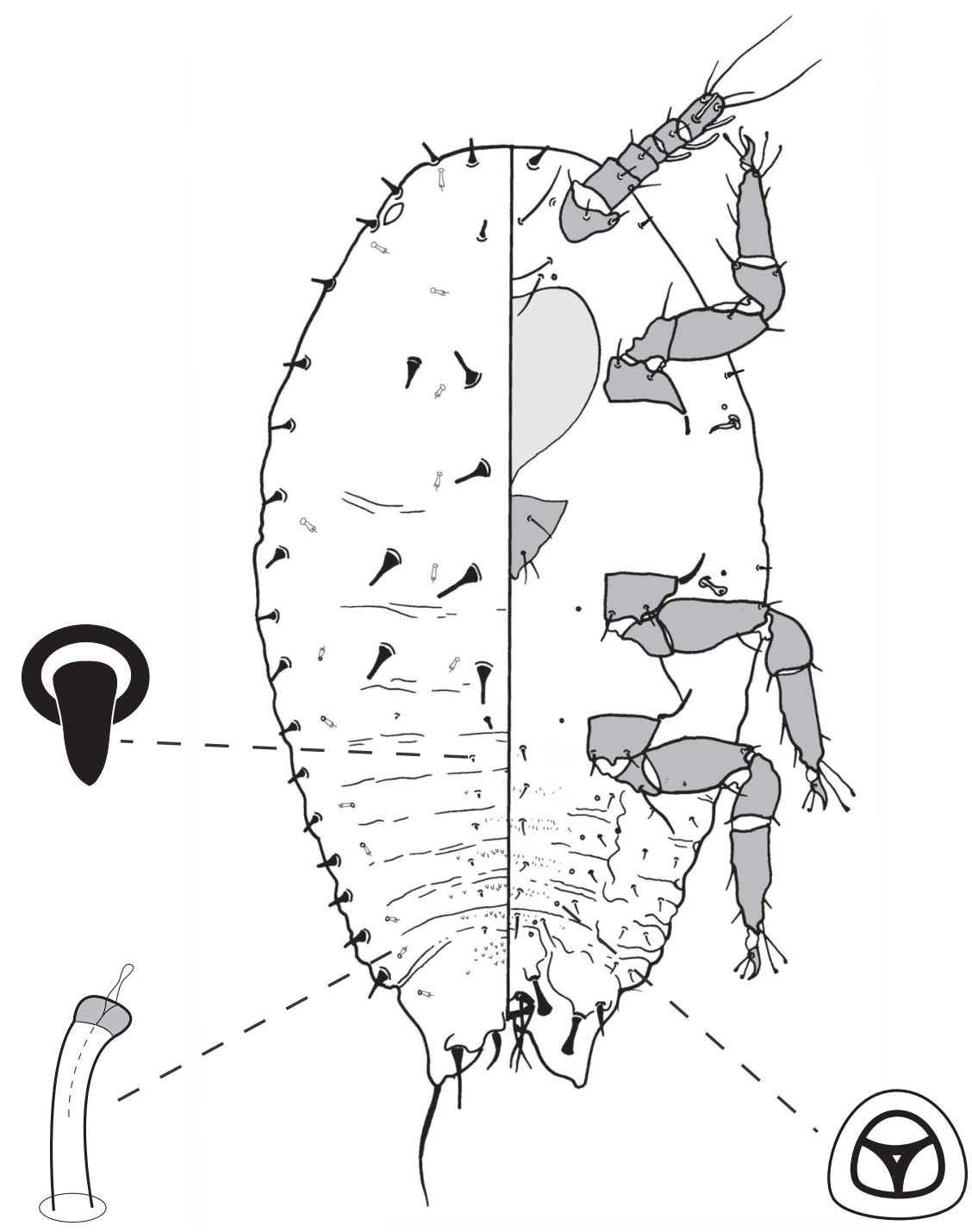

Fig. 8. First-instar nymph of Madarococcus meander, sp. nov. 
of abdomen, one medial of each coxa, one on each side of head, laterad of elongate setae, and one near each spiracle.

\section{Diagnostic features}

The first-instar nymphs of M. meander can be distinguished from the other Australian species of Madarococcus by the presence of only one disc pore near each anterior spiracle and the absence of microtubular ducts on the dorsal submedial areas of the abdomen.

\section{Etymology}

This species name is derived from the Tasmanian locality where this species is common and which will be inundated by the controversial Meander Dam. The name is a noun in apposition.

\section{Madarococcus megaventris Hardy \& Gullan, sp. nov.} (Figs $4 G, 9$ )

\section{Material examined}

Holotype. New South Wales: 1 adult female: New England National Park, ex N. moorei in tubular leaf gall, 31.iii.1972, J. W. Beardsley (ANIC).

Paratypes. New South Wales: 5 adult females: same data as holotype (BPBM); 5 adult females: New England National Park, Styx River, Forest

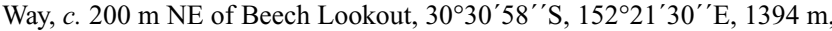
galls on leaves of N. moorei, 13.x.2006, M. D. Crisp \& D. Morris (ANIC); 6 adult females: New England NP, Point Lookout, 30 $28^{\prime} 32^{\prime \prime} \mathrm{S}$, $152^{\circ} 24^{\prime} 17^{\prime \prime} \mathrm{E}, 1506 \mathrm{~m}$, galls on leaves of N. moorei, 13.x.2006, M. D. Crisp \& D. Morris.

\section{Description}

\section{Adult female (Fig. 9)}

Live material. The adult female of M. megaventris induces finger-like galls (Fig. 4G) on the leaves of $N$. moorei. The dorsum is flat and plugs the gall opening and the venter is expanded to fill the gall cavity.

Mounted material. Body outline oblong, greatly expanded venter extending forward far beyond sclerotic dorsum, length 2.34-3.78 $\mathrm{mm}$ (holotype $2.74 \mathrm{~mm}$ ), greatest width 0.76-1.16 mm (holotype $1.14 \mathrm{~mm}$ ). Eyespot 14-16 $\mu \mathrm{m}$ wide, either incorporated into sclerotic dorsal derm, or just ventrad of it. Antennae 6-segmented; length 103-107 $\mu \mathrm{m}$; with four hairlike setae (trichoid sensialla) on segment I, three hair-like setae on II, three hair-like setae on III, one fleshy seta on IV, four hairlike setae plus one fleshy seta on $\mathrm{V}$, and $c$. seven hair-like setae plus three fleshy setae on VI. Frontal (interantennal) lobes not detected. Tentorial box 80-100 $\mu \mathrm{m}$ long, 57-80 $\mu \mathrm{m}$ wide. Labium 50-67 $\mu \mathrm{m}$ long, 50-57 $\mu \mathrm{m}$ wide; 3-segmented; seven pairs of setae on anterior surface, one pair of apical short setae, and one pair of setae on posterior surface. Spiracles $28-32 \mu \mathrm{m}$ long, 15-17 $\mu \mathrm{m}$ wide across atrium. Legs subequal (except hind tarsus 7-10 $\mu \mathrm{m}$ longer than fore or mid tarsus); coxa 25-37 $\mu \mathrm{m}$, trochanter + femur 75-95 $\mathrm{m}$, tibia $40-50 \mu \mathrm{m}$, tarsus 52-67 $\mu \mathrm{m}$, claw 14-15 $\mu \mathrm{m}$; fore coxa with five setae, mid and hind coxa each with six setae; trochanter with four setae (longest seta 27-39 $\mu \mathrm{m}$ ), fore femora each with six setae, mid and hind femur each with five setae, fore tibia with five setae, mid tibia and hind tibia each with four setae, tarsus with four setae; tarsal digitules 20-26 $\mu \mathrm{m}$, claw digitules dissimilar, 15-16 $\mu \mathrm{m}$ long, one with apical knob $5 \mu \mathrm{m}$ wide, other with apical knob $1 \mu \mathrm{m}$ wide; $c$. five translucent pores on dorsal surface of hind coxa, not detected in some specimens. Anal ring 32-42 $\mu \mathrm{m}$ wide, invaginated, bearing six setae, 60-95 $\mu \mathrm{m}$ long. Suranal setae evenly attenuated, 30-45 $\mu \mathrm{m}$ long, each seta with origin adjacent to anal invagination. Anal lobes subconic, apex bicuspid - origin of ventral lobe seta more distal than that of caudal seta, ventral surface of lobes only weakly sclerotic; lobes each with $c$. three microtubular ducts; ventral lobe seta 33-44 $\mu \mathrm{m}$ long, dorsolateral lobe seta $13-15 \mu \mathrm{m}$, dorsomedial lobe seta $15 \mu \mathrm{m}$ and projecting mesad, often overlapping opposite lobe, dorsoapical lobe seta $18-20 \mu \mathrm{m}$, caudal seta $57-76 \mu \mathrm{m}$.

Dorsum. Derm largely sclerotic; lateral portions of abdominal segments II-VII occupied by subrectangular plates; submedial areas of each abdominal segment with smaller sclerotic fragments along anterior margin; most cuticle cephalad of abdominal segment II sclerotic. Dorsal setae spinose, 5-7 $\mu \mathrm{m}$ long; two pairs of medial setae on both head and prothorax, one pair of medial setae on other segments, abdominal segments may be missing one or both setae; one submedial seta on each side of head, two submedial seta on each side of prothorax, and one submedial seta on each side of mesothorax, metathorax and abdominal segment I; lateral area of abdominal segments with transverse series of three spinose setae, medial-most seta in line with a marginal row of setae extending around thorax and head, this row most distinct on head. Macrotubular ducts 6-10 $\mu \mathrm{m}$ long, with dermal orifice raised slightly above cuticle and vestibule sclerotic; in a transverse row across each posterior abdominal segment, rows becoming more staggered cephalad. Microtubular ducts $\sim 5 \mu \mathrm{m}$ long, with structure and distribution similar to macrotubular ducts. Where incorporated into sclerotic areas of dorsum, ducts originate from circular areas of membranous cuticle $3-9 \mu \mathrm{m}$ in diameter.

Venter. Flagellate setae 5-18 $\mu \mathrm{m}$ long, in a transverse row across each of abdominal segments II-VII, three pairs of elongate $(12-30 \mu \mathrm{m})$ setae on medial portion head. Tubular ducts absent. Quinquelocular pores $4 \mu \mathrm{m}$ in diameter; clustered around spiracles, in broad submarginal band extending from bases of antennae to anal lobes. Abdominal segments II-VII not enlarged, size of venter owing to hyper-development of head, thorax and perhaps abdominal segment I.

\section{Diagnostic features}

It would be hard to confuse full-grown adult females of $M$. megaventris with any other scale insect, due to the grossly distended venter. Adult females of $M$. megaventris are most similar morphologically to those of $M$. meander and M. cunicularius [see comments under M. meander].

\section{Remarks}

Our analysis of the sequence data recovered strong support $(\mathrm{PP}=1.0)$ for a sister-group relationship between $M$. megaventris and $M$. meander, the only two species from Australia known to induce galls on Nothofagus.

\section{Etymology}

The species name is formed from the Latin terms mega, meaning large, and ventris, meaning belly, referring the spectacular distension of the ventral body surface of the adult female. 
Madarococcus montifagi (Hoy), comb. nov.

(Fig. 4H)

Eriococcus montifagi Hoy, 1962a: 108-109, fig. 40. Type data: New Zealand: South Island, Arthur's Pass, on Nothofagus solandri var. cliffortioides, 26.xii.1914, by G. Brittin. Holotype female, by original designation. Type depository: NZAC.

Acanthococcus montifagi; Miller \& Gimpel, 1996: 602. Change of combination.

\section{Material examined}

New Zealand: TO, Ohakune Ranger Station, leaves of N. solandri (NZAC); MC, Lake Pearson, State Highway 73, forest by roadside, stem nodes or curled on buds of N. solandri (ANIC, NZAC); MC, Craigieburn Forest Park, N. solandri underside leaves (NZAC).

\section{Remarks}

Hoy (1962a) mistakenly described dorsal macrotubular ducts on the adult female, but these occur along the ventral submargin in the holotype. Likewise, Hoy described the anal ring as having six setae, but eight are present. Hoy (1962a) did not record the location of the adult females on their host. Recent collections confirm that they do not form a test and are either 1, wrapped around buds at nodes, with the last few abdominal segments curled and the more anterior parts more convex and sclerotized,

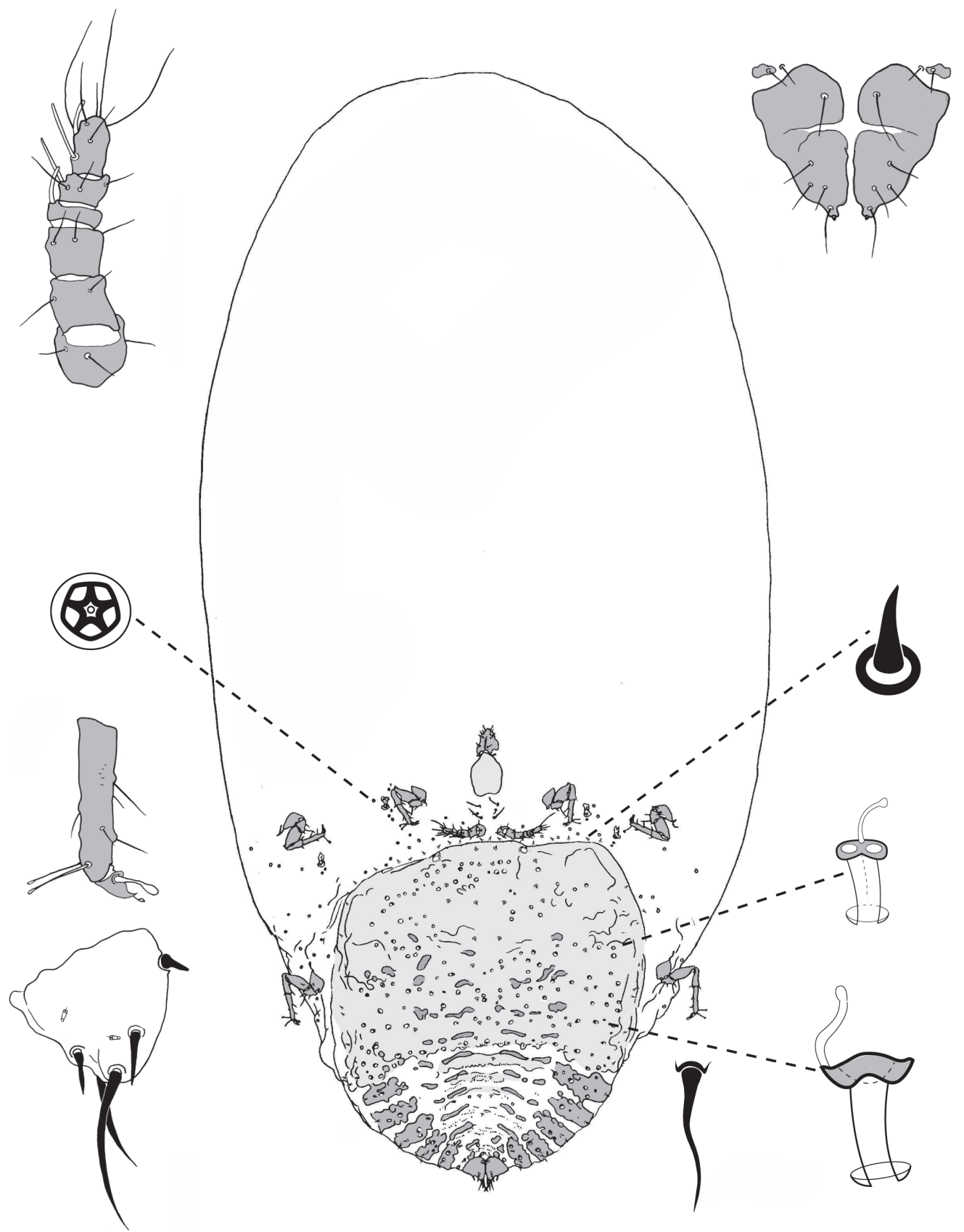

Fig. 9. Adult female of Madarococcus megaventris, sp. nov. 
or 2 , on the underside of leaves, becoming highly convex with a brood chamber beneath. Madarococcus montifagi is most similar to $M$. detectus [see comments under $M$. detectus].

Madarococcus moorei Hardy \& Gullan, sp. nov.

(Figs 4I, 10, 11)

\section{Material examined}

Holotype. New South Wales: 1 adult female: Barrington Tops State Forest, Dilgry Circle, $31^{\circ} 53^{\prime} \mathrm{S}, 151^{\circ} 32^{\prime} \mathrm{E}$, ex foliage of $N$. moorei, 25.xi.1986, PJG and S. Bhatti (ANIC).

Paratypes. New South Wales: 13 adult females: same data as holotype (10 slides ANIC, one slide BMNH, two slides USNM); 19 adult females, 2 second-instar males, 14 second-instar females and c. 65 first-instar nymphs (seven slides with first- and second instar nymphs): Brooklana, off Old Coramba Rd, on Eve Creek, $30^{\circ} 17^{\prime} \mathrm{S}, 152^{\circ} 50^{\prime} \mathrm{E}$, on foliage of $N$. moorei, 9.x.1996, PJG (ANIC); 11 adult females: New England NP, on $N$. moorei, 31.iii.1972, J. W. Beardsley (BPBM). ACT: 1 adult female: Canberra, Black Mt., Australian National Botanic Gardens, on underside of leaf of planted tree of N. moorei, 27.x.1996, PJG (ANIC).

\section{Description}

\section{Adult female (Fig. 10)}

Live material. Young females of this species feed in leaf axils and are highly cryptic. Adult females (Fig. 4I) occur primarily on the undersides of leaves and stems; body colour variable, from almost grey to dark brown, with a smooth dorsum and white wax fringe where body contacts host.

Mounted material. Body outline turbinate to circular, length 1.02-2.40 $\mathrm{mm}$ (holotype $1.98 \mathrm{~mm}$ ), greatest width 0.62-2.00 $\mathrm{mm}$ (holotype $1.56 \mathrm{~mm}$ ), dorsum larger than venter in more fully expanded specimens. Eyespot dorsad of margin, $32 \mu \mathrm{m}$ wide. Antennae 7-segmented, segments III and IV incompletely fused; length 200-225 $\mu \mathrm{m}$; with four hair-like setae (trichoid sensilla) on segment I, three hair-like setae on II, 0 setae on III, two hair-like setae on IV, one fleshy seta on segment V, 3-4 hair-like setae plus one fleshy seta on VI, and seven hairlike setae plus three fleshy setae on VII. Frontal (interantennal) lobes present, digitate. Tentorial box 125-150 $\mu \mathrm{m}$ long, 125-150 $\mu \mathrm{m}$ wide. Labium 85-100 $\mu \mathrm{m}$ long, 70-87 $\mu \mathrm{m}$ wide; 3 -segmented; seven pairs of setae on anterior surface, one pair of setae on posterior surface, and one apical pair of short setae. Spiracles 45-50 $\mu \mathrm{m}$ long, 25-27 $\mu \mathrm{m}$ wide across atrium. Legs increasing in size caudad; fore legs: coxa 57-67 $\mu \mathrm{m}$, trochanter + femur 157-185 $\mu \mathrm{m}$, tibia 75-95 $\mu \mathrm{m}$, tarsus 70-85 $\mu \mathrm{m}$; mid legs: coxa $62-87 \mu \mathrm{m}$, trochanter + femur $172-197 \mu \mathrm{m}$, tibia 77-100 $\mu \mathrm{m}$, tarsus 75-92 $\mu \mathrm{m}$; hind legs: coxa 75-95 $\mu \mathrm{m}$, trochanter + femur 180-215 $\mu \mathrm{m}$, tibia 82-105 $\mu \mathrm{m}$, tarsus 80-97 $\mu \mathrm{m}$; claw $20 \mu \mathrm{m}$ long; coxa with six setae, trochanter with four setae (longest seta 92-100 $\mu \mathrm{m}$ ), fore femur with six setae, mid and hind femur each with five setae, tibia with four setae and tarsus with six setae; tarsal digitules 32-39 $\mu \mathrm{m}$ long; claw digitules similar, 22-25 $\mu \mathrm{m}$ long, apical knob $6 \mu \mathrm{m}$ wide; translucent pores few, c. 15 in number, restricted to lateral surfaces of hind coxae and dorsodistal portions of hind femora. Anal ring 50-62 $\mu \mathrm{m}$ wide, bearing eight setae, $90-130 \mu \mathrm{m}$ long. Suranal setae spatulate, 37-50 $\mu \mathrm{m}$ long. Anal lobes subconical, 90-110 $\mu \mathrm{m}$ long, apex bicuspid - origin of dorsoapical lobe seta nearly as distal as origin of apical seta; one microtubular duct arising near base of each dorsal lobe seta, $\sim 3$ additional microtubular ducts in dorsal surface of each anal lobe; ventral lobe setae 25-36 $\mu \mathrm{m}$, dorsolateral lobe seta 20-27 $\mu \mathrm{m}$, dorsomedial lobe seta $14-20 \mu \mathrm{m}$, dorsoapical lobe seta $30-45 \mu \mathrm{m}$, caudal seta $107-117 \mu \mathrm{m}$.

Dorsum. Derm faintly nodulose. Dorsal setae of two distinct types: first type spinose, bases swollen, apices blunt to truncate, 25-32 $\mu \mathrm{m}$ long; second type curved, digitate, apices blunt, 7-10 $\mu \mathrm{m}$ long; setae of first type arranged in transverse rows, one row across each body segment except for prothorax with two transverse rows and abdominal segment VIII without setae, head with one transverse row of $\sim 6$ setae, plus one medial series on either side beginning just anterior of transverse row and wrapping around to ventral surface; smaller digitate setae restricted to submedial area of posterior abdominal segments; number of setae in each row increasing from tow on abdominal segment VII to $\sim 14$ on metathorax. Margin delineated by fringe of setae similar to those on dorsum, 17-30 $\mu \mathrm{m}$ long. Macrotubular ducts absent. Microtubular ducts 5-8 $\mu \mathrm{m}$ long, scattered over dorsum; 1-2 associated with bases of most spinose setae.

Venter. Flagellate setae mostly $7-25 \mu \mathrm{m}$ long, in a transverse row across each abdominal segment; abdominal segments II-VII each with one pair of long (20-47 $\mu \mathrm{m})$ submedial setae; longest setae medial of coxae 37-70 $\mu \mathrm{m}$; setae on head posteromedial of antennal insertions 17-70 $\mu \mathrm{m}$ long. Macrotubular ducts 10-14 $\mu \mathrm{m}$ long, in broad marginal swath, a few medial of procoxae and mesocoxae. Microtubular ducts absent. Quinquelocular pores 4-5 $\mu \mathrm{m}$ in diameter, confined to areas of abdomen, metathorax and mesothorax mesad of macrotubular ducts.

\section{Diagnostic features}

Madarococcus moorei appears to be very closely related to $M$. detectus, in that both species lack macrotubular ducts on the dorsum, have a distinct marginal fringe of spinose setae, and numerous quinquelocular pores on the ventral medial areas of the abdominal segments. Madarococcus moorei can be distinguished from $M$. detectus by lacking a pit near the anterior margin of the dorsal surface of the anal lobes, and by lacking translucent pores on the hind tibiae.

\section{Variation}

Several specimens from Brooklana differ from the type material in having more of the curved digitate setae on the dorsum; in a few specimens these completely replace the spinose setae. In all other respects the Brooklana specimens match those from the type locality.

\section{First-instar nymph (Fig. 11)}

Mounted material. Body length 209-325 $\mu \mathrm{m}$, greatest width $115-160 \mu \mathrm{m}$. Eyespot $10 \mu \mathrm{m}$ wide, ventrad of margin. Antennae 6-segmented, 64-70 $\mu \mathrm{m}$ long; with four hair-like setae (trichoid sensilla) on segment I, two hair-like setae on II, two hair-like setae on III, one fleshy seta on IV, three hair-like setae plus one fleshy seta on $\mathrm{V}$, and $\sim 6$ hair-like setae plus three fleshy setae on VI. Tentorial box 57-61 $\mu \mathrm{m}$ long, 42-48 $\mu \mathrm{m}$ wide. Labium 3-segmented, 27-34 $\mu \mathrm{m}$ long, 25-28 $\mu \mathrm{m}$ wide; seven 
pairs of setae on anterior surface, one apical pair of short setae, and one pair of setae on posterior surface. Spiracles 11-15 $\mu \mathrm{m}$ long, $5 \mu \mathrm{m}$ wide across atrium. Legs subequal; coxa 12-14 $\mu \mathrm{m}$, trochanter + femur 47-50 $\mu \mathrm{m}$, tibia 19-20 $\mu \mathrm{m}$, tarsus $28-35 \mu \mathrm{m}$, claw 9-10 $\mu \mathrm{m}$; tarsal digitules 13-17 $\mu \mathrm{m}$ long, claw digitules 10-11 $\mu \mathrm{m}$ long, ventral digitule thicker than dorsal digitule. Anal ring 17-20 $\mu \mathrm{m}$ wide, bearing six setae, 30-34 $\mu \mathrm{m}$ in length. Suranal setae spatulate, 11-14 $\mu \mathrm{m}$ long. Anal lobes 25-30 $\mu \mathrm{m}$ long, with broad, truncate apex; ventral lobe seta 11-13 $\mu \mathrm{m}$, dorsolateral lobe seta 9-10 $\mu \mathrm{m}$, dorsomedial lobe seta $10-12 \mu \mathrm{m}$, dorsoapical lobe seta $11-12 \mu \mathrm{m}$, apical seta $45-50 \mu \mathrm{m}$.

Dorsum. Derm nodulose. Dorsal setae 4-8 $\mu \mathrm{m}$ long, tapering to blunt apex, often curved; two medial series, with one seta on each side of head, two setae on each side of prothorax, and one seta on each side of mesothorax, metathorax and each of abdominal segments I-VII; one submedial series on each side of body extending from prothorax to abdominal segment I. Margin with distinct fringe of enlarged setae, 6-10 $\mu \mathrm{m}$ long, with swollen bases and blunt apices; one seta on each side of each

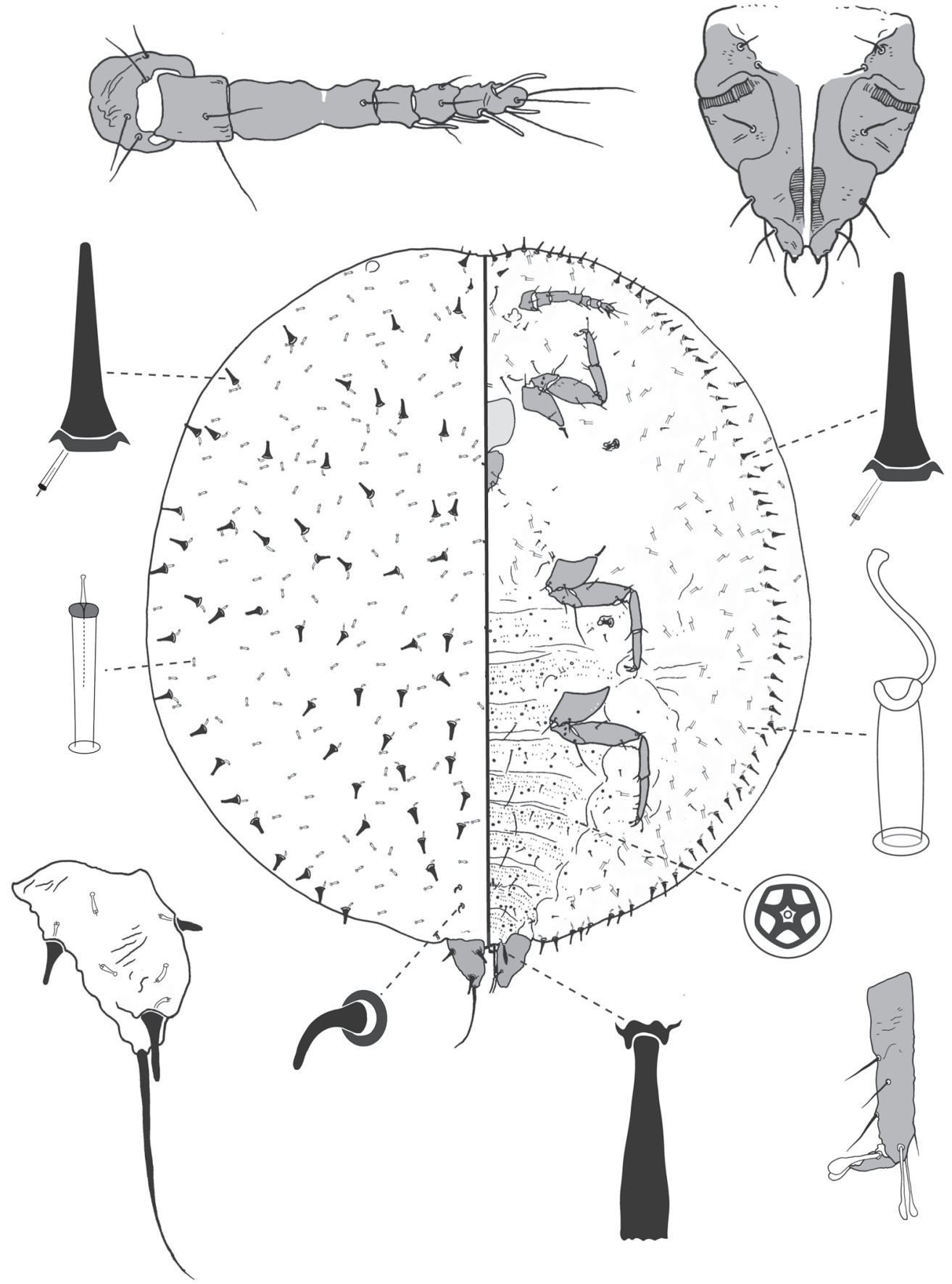

Fig. 10. Adult female of Madarococcus moorei, sp. nov. 
abdominal segment, two on each side of metathorax and mesothorax, five on each side of prothorax, and five on each side of head. Macrotubular ducts absent. Microtubular ducts $\sim 5 \mu \mathrm{m}$ long; one anterior to each anal lobe, ine laterad of medial setae on abdominal segments V and II, each thoracic segment, and one more in this submedial position just posterior of head, one mesad of marginal fringe setae on abdominal segments I and IV, plus one on each side of each thoracic segment and head.

Venter with setae 3-11 $\mu \mathrm{m}$ long, in four longitudinal rows on each side of abdomen - one marginal row on each side of body extending onto mesothorax, submarginal row on each side of body reaching metathorax, one medial and one submedial row on each side of body not extending beyond abdomen; setae medial of coxae 10-15 $\mu \mathrm{m}$; three pairs of setae on head 10-15 $\mu \mathrm{m}$ long. Macrotubular ducts and microtubular ducts absent. Some disc pores quinquelocular, most trilocular, $3 \mu \mathrm{m}$ in diameter; in one longitudinal series on either side of abdomen, laterad of medial setae, one medial of each coxa, one near each posterior spiracle, two near each anterior spiracle, and one on head lateral of elongate setae.

\section{Diagnostic features}

The first-instar nymphs of $M$. moorei can be distinguished from the other Australian species of Madarococcus by having digitate dorsal setae, all of which are much smaller than the marginal setae.

\section{Etymology}

This species is named for its host, Nothofagus moorei.

\section{Madarococcus navarinoensis (Hoy)}

Eriococcus navarinoensis Hoy, 1962b: 510-512, fig. 1. - Miller \& González, 1975: 144-146, fig. 6. Type data: Chile: Navarino Island, Puerto Williams, on N. betuloides, 1958, E. Godley. Holotype and eight paratype females, by original designation. Type depository: NZAC.

\section{Material examined}

Chile: X Region, Parque Nacional Puyehue, Anticura, ex test on leaves of N. nitida (BME); IX Region, Parque National Huerquehue, ex test on leaves

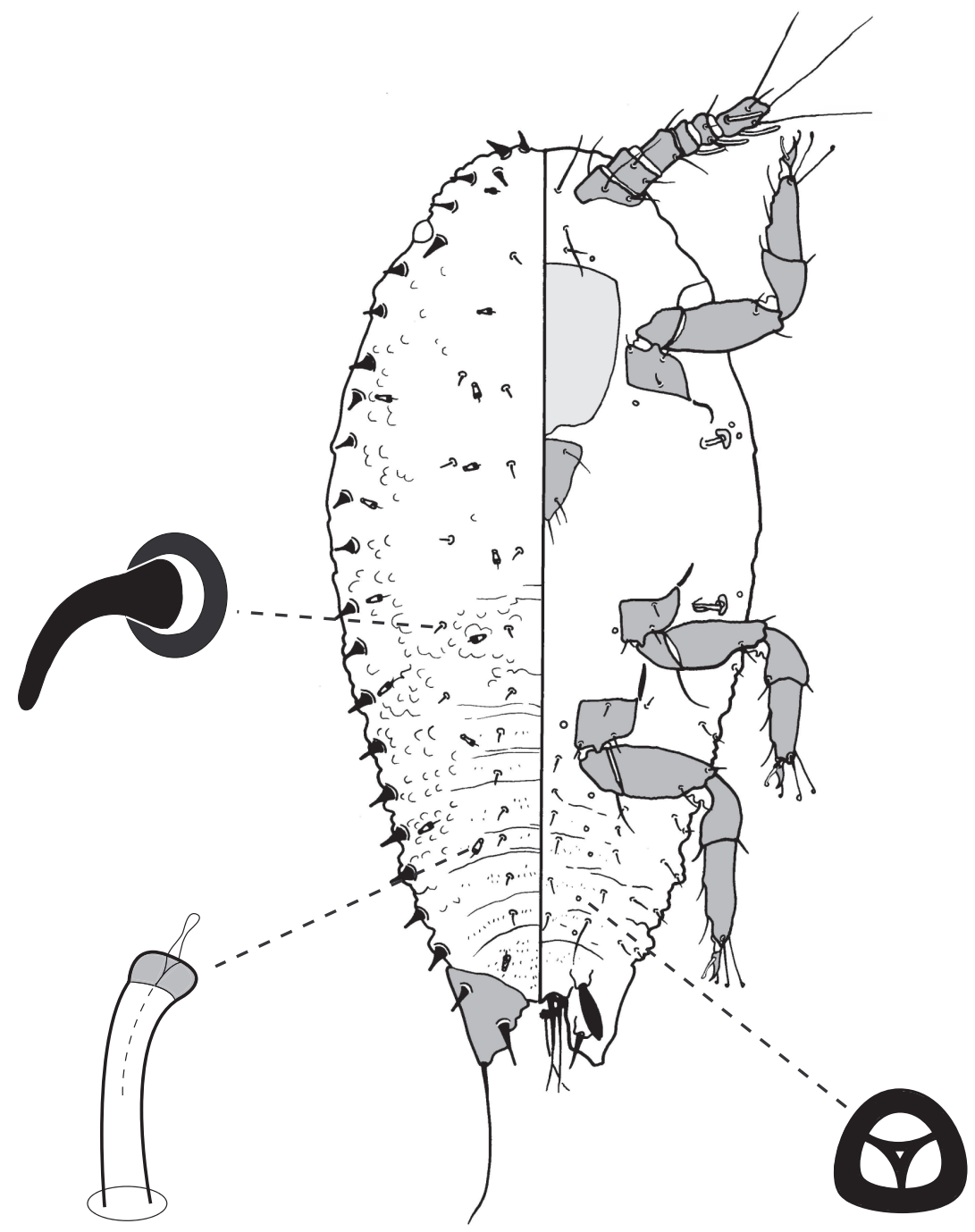

Fig. 11. First-instar nymph of Madarococcus moorei, sp. nov. 
of N. dombeyi (ANIC, BME); X Region, near Rio Blanco, ex test on leaves of $N$. nitida (ANIC, BME) [see remark on these specimens below].

\section{Remarks}

The adult females of $M$. navarinoensis are very similar to those of $M$. chilensis [see comments under $M$. chilensis] and $M$. rhadinothrix. Miller and González (1975) separate the adult females of $M$. navarinoensis from those of $M$. rhadinothrix by 1, 19-31 dorsal setae on abdominal segment $\mathrm{V}$ on $M$. navarinoensis (9-14 on $M$. rhadinothrix); 2, setae on dorsomedial areas of head and thorax noticeably smaller than those on abdominal margin on M. navarinoensis (setae on dorsomedial areas of head and thorax $c$. same size as those along abdominal margin on M. rhadinothrix); 3, 7-segmented antennae on M. navarinoensis (6-segmented in M. rhadinothrix); 4, tibia:tarsus ratio 0.9-1.1 for $M$. navarinoensis (0.7-0.8 for $M$. rhadinothrix), and 5, anal lobes smaller, broader and less protuberant on $M$. navarinoensis than on M. rhadinothrix. They also suggest that the presence of translucent pores on the hind tibiae can be used to distinguish the adult females of $M$. rhadinothrix from those of $M$. navarinoensis, however, the figures show the reverse: translucent pores on the hind tibiae of $M$. navarinoensis and translucent pores absent from this location on $M$. rhadinothrix.

We have examined material from Rio Blanco in Chile and it is near to $M$. navarinoensis (with translucent pores on hind tibiae) except that only $c .14$ setae are present on the dorsal surface of abdominal segment $\mathrm{V}$, and the anal lobe is as long and protuberant as it is on $M$. rhadinothrix. In the phylogenetic analysis of the molecular data, we refer to the Rio Blanco material as $M . \mathrm{nr}$ navarinoensis. The type locality, Navarino Island, is located at latitude $55^{\circ} \mathrm{S}$, but the species has been recorded from several more northerly localities at different altitudes in Chile and also occurs in Argentina. It is possible that some observed variation in setal and other features may be due to environmental effects, especially developmental temperature.

Madarococcus nelsonensis (Hoy), comb. nov.

(Fig. 4J)

Eriococcus nelsonensis Hoy, 1962a: 31, 114-115, fig. 43. Type data: New Zealand: South Island, Takaka Hill, on Nothofagus fusca, 15.x.1935, G. Brittin. Holotype and eight paratype females, by original designation. Type depository: NZAC.

Acanthococcus nelsonensis; Miller \& Gimpel, 1996: 602. Change of combination.

\section{Material examined}

New Zealand: BR, Springs Junction, Palmer Rd, leaf axils or stem of N. fusca (NZAC); MC, Banks Peninsula, Hinewai Reserve, $N$. fusca stems in leaf bud axils (Fig. FJ) (NZAC).

\section{Remarks}

In addition to the host record for the type material, Hoy (1962a) provides two other host records, $N$. solandri and N. menziesii, both of which were collections by G. Brittin. The enlarged hind coxae of $M$. nelsonensis might be confused with those of $M$. cavellii. Otherwise, the two species are easy to separate, $M$. cavellii having numerous spinose setae on the lateral areas of the venter, and M. nelsonensis having setae on the posterior abdominal segments much smaller than those found on the rest of the dorsum. Madarococcus nelsonensis is most similar to $M$. argentifagi, $M$. rubrifagi, and $M$. nothofagi [see comments under $M$. nothofagi], but can be distinguished from these three species by the greatly enlarged hind coxae and numerous microtubular ducts on the ventromedial surface of the head.

Madarococcus nothofagi (Hoy), comb. nov.

Eriococcus nothofagi Hoy, 1962a: 31, 120-121, fig. 46. Type data: New Zealand: South Island, Owaka, on Nothofagus menziesii, 11.xi.1958, J. M. Hoy. Holotype and 23 paratype females, by original designation. Type depository: NZAC.

Acanthococcus nothofagi; Miller \& Gimpel, 1996: 602. Change of combination.

\section{Remarks}

This species is similar to $M$. argentifagi, $M$. rubrifagi, and M. nelsonensis. Each of these species has the following combination of features: 1, pairs of minute setae on the posterior abdominal segments; 2, absence of a marginal fringe of enlarged setae but a characteristic arrangement of dorsal setae on the posterior abdominal segments: one enlarged seta on the margin of each abdominal segment plus one enlarged seta just medial of the margin, and 3, numerous macrotubular ducts on the dorsum and ventral submargin. Madarococcus nothofagi can be easily distinguished from the other three species by the short apical lobe (caudal) setae, which are shorter than the dorsoapical lobe setae. This feature also is found in the Australian species M. cunninghamii.

Madarococcus occultus Hardy \& Gullan, sp. nov. (Fig. 12)

\section{Material examined}

Holotype. Tasmania: 1 adult female: $32 \mathrm{~km}$ [20 miles] W of Maydena, in ovisac under twig bract on N. cunninghamii, 26.vi.1972, J. W. Beardsley (ANIC).

Paratypes. Tasmania: 16 adult females (11 slides), eight of which are in poor condition, badly damaged by fungus, same data as holotype (BPBM).

\section{Description}

Adult female (Fig. 12)

Live material. The female of this species lives under the bracts of $N$. cunninghamii with its posterior margin protruding (McQuillan, 1993). The body of the adult female is orangebrown.

Mounted material. Body outline ovate to turbinate, length $1.12-1.44 \mathrm{~mm}$ (holotype $1.28 \mathrm{~mm}$ ), greatest width $0.96-1.1 \mathrm{~mm}$ (holotype $0.98 \mathrm{~mm}$ ). Eyespot just ventrad of margin, 15-20 $\mu \mathrm{m}$ wide. Antennae 6-segmented; length 120-137 $\mu \mathrm{m}$; with four hair-like setae (trichoid sensilla) on segment I, three hair-like setae on segment II, 2-3 hair-like setae on segment III, one fleshy seta on segment IV, five hair-like setae and one fleshy seta on segment $\mathrm{V}$, and $c$. six hair-like setae plus three fleshy setae on segment VI. Frontal (interantennal) lobes not detected. Tentorial box 105-112 $\mu \mathrm{m}$ long, 87-100 $\mu \mathrm{m}$ wide. Labium 55-70 $\mu \mathrm{m}$ long, 50-60 $\mu \mathrm{m}$ wide; 3-segmented, basal segment indicated 
only by presence of basal segment setae; seven pairs of setae on anterior surface, one pair of setae on posterior surface, and one apical pair of short setae. Spiracles 35-48 $\mu \mathrm{m}$ long, 21-30 $\mu \mathrm{m}$ wide across atrium. Hind legs larger than fore or mid legs; fore and mid legs: coxa 30-42 $\mu \mathrm{m}$, trochanter + femur 83-90 $\mu \mathrm{m}$, tibia 37-44 $\mu \mathrm{m}$, tarsus $45-55 \mu \mathrm{m}$; hind legs: coxa 47-52 $\mu \mathrm{m}$, trochanter + femur $100-110 \mu \mathrm{m}$, tibia $45-50 \mu \mathrm{m}$, tarsus 52-62 $\mu \mathrm{m}$; claw 15-18 $\mu \mathrm{m}$ long; coxa with six setae, trochanter with three setae, longest seta $45-50 \mu \mathrm{m}$ long, fore femur with six setae, mid and hind femur each with five setae, tibia with four setae, and tarsus with six setae; tarsal digitules 24-29 $\mu \mathrm{m}$ long; claw digitules asymmetrical, 15-20 $\mu \mathrm{m}$ long, one with apical knob $3 \mu \mathrm{m}$ wide, other with apical knob $2 \mu \mathrm{m}$ wide; translucent pores very large, 4-12 $\mu \mathrm{m}$ wide, dorsal surfaces of hind coxae, femora and tibiae appearing latticed, hind coxae each with $c$. 15 pores on ventral surface and c. 50 pores on dorsal surface, hind femora each with $c .50$ pores on dorsal surface, and hind tibiae each with $c .10$ pores on dorsal surface. Anal ring 30-34 $\mu \mathrm{m}$ wide, bearing six setae, 35-45 $\mu \mathrm{m}$ long. Suranal setae spatulate, $12-15 \mu \mathrm{m}$ long. Anal lobes $45-52 \mu \mathrm{m}$ long, with rounded tooth on medial margin distal of dorsoapical lobe seta, dorsal surface invested with two microtubular ducts;
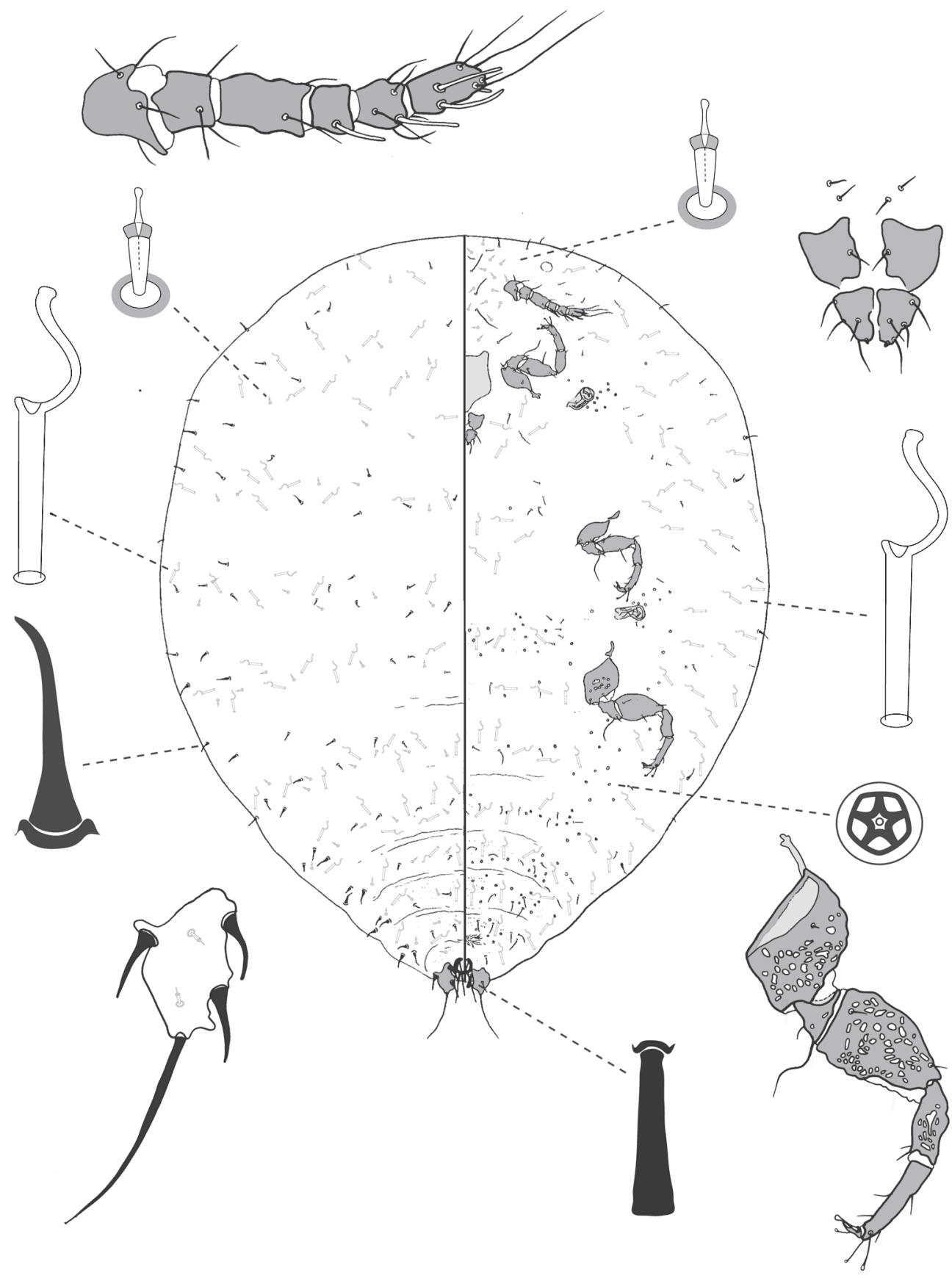

Fig. 12. Adult female of Madarococcus occultus, sp. nov. 
ventral lobe seta $14-16 \mu \mathrm{m}$, dorsolateral lobe seta $27-32 \mu \mathrm{m}$, dorsomedial lobe seta 27-30 $\mu \mathrm{m}$, dorsoapical lobe seta 27-32 $\mu \mathrm{m}$, caudal seta $65-81 \mu \mathrm{m}$ long.

Dorsum. Derm membranous. Dorsal setae 7-20 $\mu \mathrm{m}$ long, slender, slightly curved, with blunt apices; arranged in a transverse row across each body segment, rows becoming increasingly staggered cephalad; posterior abdominal segments each with a cluster of three enlarged setae (17-28 $\mu \mathrm{m}$ long) on each side near margin: two setae parallel to margin and one just ventrad of these, setae comprising marginal clusters becoming more widely dispersed cephalad. Macrotubular ducts 20-28 $\mu \mathrm{m}$ long, orifice c. $2 \mu \mathrm{m}$ in diameter; densely distributed over dorsum. Microtubular ducts c. $5 \mu \mathrm{m}$ long; found throughout dorsum, not associated with the bases of enlarged setae.

Venter. Flagellate setae 7-25 $\mu \mathrm{m}$ long, in a transverse row across medial portion of each abdominal segment plus some near margin, in clusters anteromedial of each mid and hind coxa, longest setae in these clusters $27-32 \mu \mathrm{m}$ long, longest setae on head, medial of antennal insertions, 40-50 $\mu \mathrm{m}$ long. Macrotubular ducts like those on dorsum, found throughout venter. Microtubular ducts confined to a narrow medial band running between antennae from anterior margin of head. Quinquelocular pores $4 \mu \mathrm{m}$ in diameter, in bands across abdominal segments, most dense around vulva and along a line running from anal lobes to hind coxae, in clusters around each spiracle, otherwise largely absent from head and thorax.

\section{Diagnostic features}

Surprisingly, $M$. occultus more closely resembles the Chilean species M. eurythrix than it does any of the Australasian species [see comments under $M$. eurythrix]. Nucleotide sequences of freshly collected specimens of M. occultus are needed to check its genetic affinities.

\section{Etymology}

This species takes its name from the Latin word meaning hidden or secret, referring to its cryptic habit under bracts of N. cunninghamii.

Madarococcus osculus Hardy \& Gullan, sp. nov. (Fig. 13)

\section{Material examined}

Holotype. New South Wales: 1 adult female: New England National Park, ex underside of leaf of N. moorei, 31.iii.1972, J. W. Beardsley (ANIC).

Paratypes. New South Wales: 7 adult females, 1 pharate adult female partially enclosed in second-instar exuviae, and 1 adult male (6 slides): same data as holotype (BPBM).

Other material examined and excluded from type series. Tasmania: 1 adult female, Mt Field NP, Tarn Shelf, ex N. gunnii (TASAG); 1 adult female, Mt Field NP, Lyrebird Walk, ex N. cunninghamii, (TASAG); 1 adult female same data as previous except HeEr16 (TASAG).

\section{Description}

\section{Adult female (Fig. 13)}

Mounted material. Body outline elliptical, length 1.45-1.68 $\mathrm{mm}$ (holotype $1.64 \mathrm{~mm}$ ), greatest width 0.86-1.02 $\mathrm{mm}$ (holotype $0.99 \mathrm{~mm}$ ). Eyespot $24-30 \mu \mathrm{m}$ wide, on margin. Antennae 7-segmented, length 300-395 $\mu \mathrm{m}$; with three hair-like setae on segment I, one hair-like seta on II, 0 setae on III, two hair-like setae on IV, one fleshy seta on V, two hair-like setae plus one fleshy seta on VI, and seven hair-like setae plus three fleshy setae on VII. Frontal (interantennal) lobes present, digitate. Tentorial box 127-175 $\mu \mathrm{m}$ long, 135-153 $\mu \mathrm{m}$ wide. Labium 60-75 $\mu \mathrm{m}$ long, 87-112 $\mu \mathrm{m}$ wide; composed of two fused segments, basal segment lost; five pairs of seta on anterior surface, one apical pair of short setae, and one pair of setae on posterior surface. Spiracles 57-80 $\mu \mathrm{m}$ long, 29-40 $\mu \mathrm{m}$ wide across atrium, atria sclerotic. Legs increasing in size caudad; fore legs: coxa 67-82 $\mu \mathrm{m}$, trochanter + femur 215-260 $\mu \mathrm{m}$, tibia 110-132 $\mu \mathrm{m}$, tarsus 100-107 $\mu \mathrm{m}$; mid legs: coxa 87-105 $\mu \mathrm{m}$, trochanter + femur 237-295 $\mu \mathrm{m}$, tibia 120-137 $\mu \mathrm{m}$, tarsus 107-120 $\mu \mathrm{m}$; hind legs: coxa 100-132 $\mu \mathrm{m}$, trochanter + femur 255-290 $\mu \mathrm{m}$, tibia 125-137 $\mu \mathrm{m}$, tarsus 112-125 $\mu \mathrm{m}$; claw 20-25 $\mu \mathrm{m}$; fore coxa with six setae, mid coxa and hind coxa each with five setae, trochanter with five setae (longest seta $72-125 \mu \mathrm{m}$ ), fore femur with five setae, mid and hind femur each with four setae (holotype has five setae on one hind femur), tibia with three setae, tarsus with five setae; tarsal digitules $\sim 40 \mu \mathrm{m}$ long; claw digitules dissimilar, 26-28 $\mu \mathrm{m}$ long, one with apical knob $10 \mu \mathrm{m}$ wide, other with apical knob 4-6 $\mu \mathrm{m}$ wide; translucent pores on both surfaces of hind coxae, dorsal surface of each hind coxa with $c$. 30 pores concentrated laterally, ventrolateral surface of each hind coxa with c. 20 pores, medial region of ventral surface without pores, hind femora each with 15-20 translucent pores on dorsal surface. Anal ring 55-67 $\mu \mathrm{m}$ wide, bearing eight setae, $85-110 \mu \mathrm{m}$ long. Suranal setae spatulate, $37-50 \mu \mathrm{m}$ long. Anal lobes with oblique apex; dorsal surface of lobes invested with 7-9 microtubular ducts; ventral lobe seta 34-45 $\mu \mathrm{m}$ long, spinose or spatulate (perhaps always spatulate and only appearing spinose under certain orientations), arising on or near posterior margin, dorsolateral lobe seta $15-20 \mu \mathrm{m}$, dorsomedial lobe seta 10-15 $\mu \mathrm{m}$, dorsoapical lobe seta $15-25 \mu \mathrm{m}$, caudal seta 70-86 $\mu \mathrm{m}$.

Dorsum. Derm nodulose. Dorsal setae 8-11 $\mu \mathrm{m}$ long, spinose, with acute apices; in a transverse line across each posterior body segment, lines disintegrating cephalad, becoming random array. Margin delineated by fringe of enlarged setae, 21-31 $\mu \mathrm{m}$ long, with blunt apices; two setae on each side of each abdominal segment, three setae on each side of metathorax and mesothorax, five setae on each side of prothorax, and eight setae between eyes on head. Macrotubular ducts $\sim 15 \mu \mathrm{m}$ long, microtubular ducts $\sim 5 \mu \mathrm{m}$ long; both duct types densely distributed over dorsum, one microtubular duct associated with base of each marginal fringe seta.

Venter. Flagellate seta mostly $10-40 \mu \mathrm{m}$ long, in an irregular disrupted transverse row across each abdominal segment; one submedial pair of long setae $(42-70 \mu \mathrm{m})$ on abdominal segments II-VII; setae medial of coxae 60-75 $\mu \mathrm{m}$; setae on head posteromedial of antennal insertions $21-75 \mu \mathrm{m}$. Macrotubular ducts in marginal series, plus disjunct clusters in submarginal zones of abdominal segments. Microtubular ducts occurring amongst submarginal clusters of macrotubular ducts, plus a few in marginal zone of head and thorax. Quinquelocular pores 4-5 $\mu \mathrm{m}$ in diameter, in tight band extending from anal lobes to posterior spiracles, some incorporated into sclerotic peritremes of spiracles, pores radiating out from anterior spiracles to margin. 


\section{Diagnostic features}

The adult female of M. osculus is unlikely to be confused with that of any other Madarococcus species. It is the only species to have 1 , quinquelocular pores incorporated into sclerotic spiracular peritremes; 2, antennal segment III approximately as long as segments IV $+\mathrm{V}+\mathrm{VI}$, and 3, small dorsal setae with acute apices. Madarococcus osculus and M. cunninghamii are the only Madarococcus species in which the labium is 1-segmented (apical and sub-apical segments completely fused and basal segment setae absent). The adult females of M. osculus can be distinguished from the adult females of
M. cunninghamii by 1 , numerous macrotubular ducts on the dorsum and venter (macrotubular ducts restricted to areas posterolateral of vulva in $M$. cunninghamii); 2, frontal lobes well developed (rudimentary in M. cunninghamii), and 3, caudal seta longer than dorsoapical lobe seta (caudal seta shorter than dorsoapical lobe seta in M. cunninghamii).

\section{Remarks}

The adult females from $N$. gunnii and $N$. cunninghamii in Tasmania were beaten from the foliage and thus their location on the host plant is unknown. These three females differ from
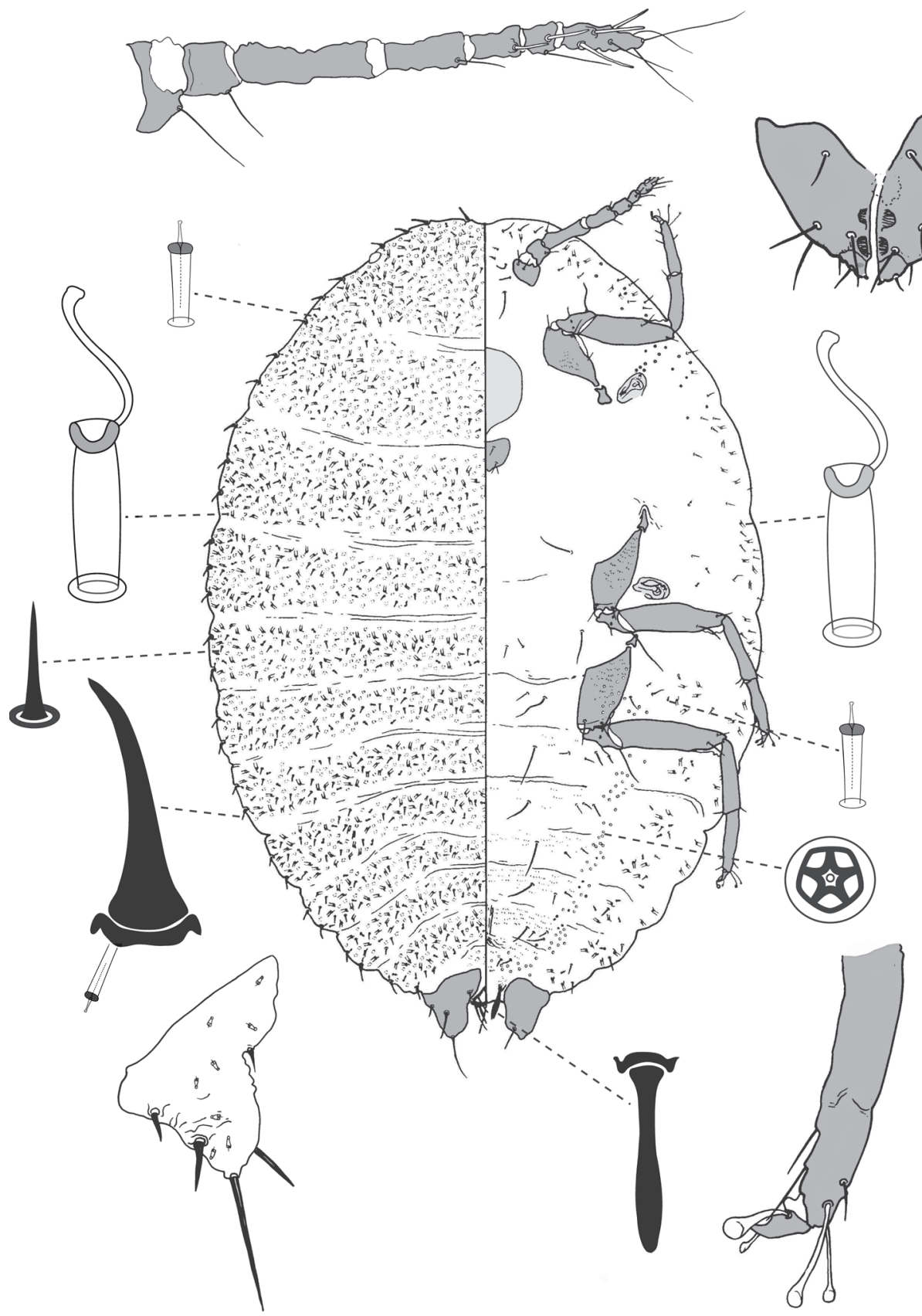

Fig. 13. Adult female of Madarococcus osculus, sp. nov. 
the type specimens of M. osculus in having far fewer macrotubular ducts and setae on the dorsum (Tasmanian specimens with $c$. 20 macrotubular ducts and four setae on abdominal segment VII; New South Wales specimens with $c$. 60 macrotubular ducts and 16 setae on abdominal segment VII), and thus are excluded from the type series. The Tasmanian population may be a geographic variant of $M$. osculus or a new species. The specimens from $N$. gunnii are only eriococcids known from this Nothofagus species.

\section{Etymology}

This species name is taken from the Latin term osculum, meaning a small mouth, referring to the reduced labium.

Madarococcus papillosus (Hoy), comb. nov.

Sisyrococcus papillosus Hoy, 1962a: 181, 184-185, fig. 74. Type data: New Zealand: South Island, Motueka, Takaka Road [Takaka Hill for paratypes], on Nothofagus fusca, 8.ii.1920 [on N. menziesii, 15.x.1935 for paratypes], by G. Brittin. Holotype and six paratype females, by original designation. Type depository: NZAC.

\section{Material examined}

New Zealand: TO, Ohakune, Moore St, N. menziesii, (ANIC); NN, Kahurangi NP, Riwaka Resurgence, buds in leaf axils of N. menziesii (ANIC); NN, Takaka Hill Walkway, leaf buds in stem axils of N. menziesii (NZAC); DN, Dunedin Botanic Gardens, N. menziesii, stems in leaf bud axils (NZAC).

\section{Remarks}

Madarococcus papillosus is most similar to M. intermedius [see comments under $M$. intermedius]. In life, adult females of M. papillosus are pale green to pale or dark brown with a pale creamish dorsomedial longitudinal stripe and are covered with dorsal glassy wax tubes that each enclose a spiky seta. Small nymphs are pink to pale orange in life.

Madarococcus podocarpi (Hoy), comb. nov.

Eriococcus podocarpi Hoy, 1962a: 31, 134-135, 198, 206, fig. 53. Type data: New Zealand: South Island, Motueka, on Dacrycarpus dacrydioides (previously in Podocarpus), 17.xi.1918, by G. Brittin. Holotype female, by original designation. Type depository: NZAC.

Acanthococcus podocarpi; Miller \& Gimpel, 1996: 603. Change of combination.

\section{Material examined}

New Zealand: BR, St Arnaud, Lake Rotoiti (ANIC, NZAC).

Remarks

Madarococcus podocarpi was collected recently on N. fusca. The holotype specimen taken from Dacrycarpus dacrydioides represents the only collection of a Madarococcus species from a host other than Nothofagus. If the host was not misidentified, the most likely explanation for the original host record is either a labelling error or a chance occurrence on the wrong plant. It is impossible to identify $M$. podocarpi with the key of Hoy (1962a), as he relies incorrectly on the absence of translucent pores from the hind coxae. Madarococcus podocarpi is quite similar to M. maskelli [see comments under M. maskelli].

\section{Madarococcus pulchellus (Maskell)}

Rhizococcus pulchellus Maskell, 1891: 143-144, pl. VII, Figs 1-5. Type data: New Zealand: Rimutaka Hills near Wellington, Capleston, Reefton, Picton, on Nothofagus solandri (as Fagus), viii.1889, W. M. Maskell. Lectotype female (here designated; see below for details and discussion) and four paralectotype females (see below). Type depositories: NZAC and USNM.

Nidularia pulchellus; Lindinger, 1933: 116. Change of combination.

Madarococcus pulchellus; Hoy, 1962a: 6, 151, 158-159, fig. 64. Change of combination.

\section{Material examined}

New Zealand: NC, c. $12 \mathrm{~km} \mathrm{~S}$ of Lewis Pass, leaf undersides of N. solandri var. cliffortioides (ANIC); MC, Klondyke Corner, leaf undersides of N. solandri var. cliffortioides (ANIC).

\section{Remarks}

Hoy (1962a) illustrated and redescribed the adult female of this species. Although Maskell (1891) reported this species from three Nothofagus species, the only slide-mounted material was collected from $N$. solandri. Thus Hoy (1962a) recognised only specimens from this host as M. pulchellus. Thus we have designated a lectotype for this species in order to fix and stabilise Maskell's concept of the name. The lectotype slide of this species is labelled: 'Rhizococcus pulchellus / female 2ndstage / on Fagus solandri / Aug. 1889 W.M.M.' but the specimen is a young adult female $(1.6 \mathrm{~mm}$ long and $0.93 \mathrm{~mm}$ wide). Another slide-mounted Maskell specimen has the same label except 'female - adult' however it is an uncleared female with waxy filaments and cuticular details are obscured. Thus it was not selected as the lectotype, but we have labelled it as a paralectotype. Both of these original Maskell slide-mounts are in the NZAC together with a Hoy slide-mount labelled 'PLESIOTYPE' (remounted by RCH) of an adult female of this species from Maskell Collection 103 collected on N. solandri in August 1889. We also consider this latter female to be a paralectotype. The USNM has one slide-mount of an adult female from Maskell collection No 103, and thus we also recognise this specimen as a paralectotype. In addition the USNM as one box of dry material apparently from Maskell that was acquired as part of the Cockerell Collection and labelled as from New Zealand on 'Fagus' (D. R. Miller personal communication), but we are uncertain of the type status of this material.

Madarococcus pulchellus is closely related to $M$. viridulus, but the two species occur on different hosts ( $N$. solandri and $N$. fusca, respectively). Both species are characterised by 1 , rugose anal lobes, each with a large and conspicuous pit in the dorsal surface near the anterior margin; 2, a complete absence of macrotubular ducts; 3 , dorsal body surface densely beset with enlarged setae that in life secrete a glassy wax that forms a tube around the seta and projects from the body, and 4 , in life, a light green body colour with patterned areas of white cuticle on the dorsum. Madarococcus pulchellus is distinguished by having the size of the dorsal setae vary continuously, in contrast to the dorsal setae in $M$. viridulus that cluster into two discrete size classes. 
Madarococcus raithbyi (Maskell), comb. nov.

Eriococcus raithbyi Maskell, 1890: 145-146, pl. IX, figs 1-18. - Hoy, 1962a: 138-139, fig. 55. Type data: New Zealand: on Nothofagus menziesii (as Fagus menziesii). Lectotype female, by subsequent designation of Deitz \& Tocker, 1980: 48. Type depositories: NZAC, BNHM, USNM.

Nidularia raithbyi; Lindinger, 1933: 116. Change of combination.

Acanthococcus raithbyi; Miller \& Gimpel, 1996: 603. Change of combination.

\section{Remarks}

Hoy $(1962 a)$ illustrated and redescribed the adult female of this species based on one slide-mounted female from Maskell (this specimen is now the lectotype) plus eight additional specimens from Maskell's duplicate material, one of which he designated as a plesiotype. The lectotype slide is a Maskell original slide, labelled Holotype by Brittin then lectotype by Deitz \& Tocker. Hoy's 'plesiotype' is labelled 'Eriococcus raithbyi/ Maskell Collection/ X Nothofagus menziesii/ 1889' and 'Stained \& remounted by RC Henderson July 2006.' Hoy (1962a) described quinquelocular pores on the dorsum, however these pores occur only on the ventral body surface. Hoy also failed to note the presence of relatively enlarged setae on the margin, forming a loose fringe. There is some probable paralectotype material in the USNM but the status of Maskell material sent to the USA is uncertain. The USNM has two slides (one with an adult female containing several embryos and the other with several firstinstar nymphs) labelled as Maskell No. 115, as well as two boxes of dry material (one has Maskell No. 54 and the other is a large circular box labelled from New Zealand on Fagus in Maskell's handwriting) (D. R. Miller personal communication). There is no Maskell material in the NZAC with the numbers 54 or 115. There are also two slides in the BMNH that may be paralectotype material. One slide has an adult female with the data: 'Eriococcus raithbyi Mask. ex-coll. Maskell', and on the envelope are the additional data 'on Fagus menziesii, New Zealand, BM 1940-180'. The other slide has two specimens, possibly nymphs (stylets in a loop), in badly deteriorated mountant, with the legend 'Eriococcus raithbyi Maskell, New Zealand, ex- coll. Maskell, July 1890, BM 1945-121'The second label simply has 'R Newstead' (J. H. Martin personal communication).

\section{Madarococcus rhadinothrix (Miller \& González)}

Eriococcus chilensis Miller \& González, 1975: 146-147, fig. 7. Type data: Chile: near Pucón, ex N. obliqua, 18.xii.1971, R. González. Holotype and four paratype females, by original designation. Type depositories: UCH; BMNH; BME; USNM.

\section{Material examined}

Argentina: c. $60 \mathrm{~km} \mathrm{NW}$ of Bariloche, near Chilean border, on leaves of $N$. dombeyi (ANIC). Chile: Parque Nacional Alerce Andino, on leaves of N. nitida (ANIC).

\section{Remarks}

Adult females of $M$. rhadinothrix are very similar to those of the Chilean species M. chilensis and M. navarinoensis [see comments under M. chilensis and M. navarinoensis]. In the original description (Miller and González 1975), the field features of this species were recorded as unknown. The adult females listed above as additional material had creamy orange tests and the specimens from Chile had eggs under their tests; tests mostly occurred on the underside of leaves but occasionally in twig axils.

\section{Madarococcus rotundus (Hoy), comb. nov.}

(Fig. 4K)

Eriococcus rotundus Hoy, 1962a: 142, fig. 57. Type data: New Zealand: South Island, Nelson, Stanley Brook, on Nothofagus solandri var. solandri, 04.iii.1960, J. M. Hoy. Holotype and 13 paratype females by original designation. Type depository: NZAC.

Acanthococcus rotundus; Miller \& Gimpel, 1996: 603. Change of combination

\section{Material examined}

New Zealand: AK, Hunua Range, Mangatangi Trig Track, N. truncata (NZAC); NN, Harwoods Hole, N. solandri underside leaves and on leaf buds (NZAC); BR, Inangahua, Fletchers Creek, N. fusca, (NZAC); BR, Reefton Saddle, Slab Hut Creek, N. fusca (NZAC); MC, Banks Peninsula, Hinewai Reserve, $N$. fusca, distorted curled shoots and underside of leaves near margin 21.viii.2001, on new leaf shoots 1.xi. 2001, leaves near margin 22.i.2002, on distorted curled shoots 4.vi.2002 (NZAC).

\section{Remarks}

Adult females of $M$. rotundus frequently occur on the underside of leaves and have a distinctive test pattern composed of curled wax strands (Fig. 4K). This species is very similar to M. latilobatus [see comments under M. latilobatus].

Madarococcus rubrifagi (Hoy), comb. nov.

Eriococcus rubrifagi Hoy, 1962a: 144, fig. 58. Type data: New Zealand: North Island, Rangataua, on Nothofagus fusca, 23.iii.1960, J. M. Hoy. Holotype and one paratype female, by original designation. Type depository: NZAC.

Acanthococcus rubrifagi; Miller \& Gimpel, 1996: 603. Change of combination.

\section{Material examined}

New Zealand: BR Reefton Saddle, Slab Hut Creek, N. fusca (NZAC).

\section{Remarks}

Madarococcus rubrifagi is very similar to $M$. argentifagi [see comments under M. argentifagi]. It is also similar to M. nelsonensis and $M$. nothofagi [see comments under M. nothofagi]. The adult females of M. rubrifagi differ from those of M. nelsonensis by having the hind legs approximately as large as the fore and mid legs (hind legs much larger than fore and mid legs in M. nelsonensis). The adult female of $M$. rubrifagi can be distinguished from those of $M$. nothofagi by having caudal setae longer than the dorsoapical lobe setae (the opposite is true in $M$. nothofagi) and 7-segmented antennae (6-segmented in M. nothofagi)

\section{Madarococcus viridulus Hoy}

(Fig. 4L)

Madarococcus viridulus Hoy, 1962a: 162-163, fig. 66. Type data: New Zealand: North Island, Ohakune, on Nothofagus fusca, 10.ii.60, J. M. Hoy. Holotype and 28 paratype females, by original designation. Type depository: NZAC. 


\section{Material examined}

New Zealand: BP, Rereauira Swamp, N. truncata (NZAC); NN, Flora Saddle, $N$. fusca underside leaves (NZAC); NN, Golden Bay, undersides of leaves of N. truncata (NZAC); NN, Whangamoa Saddle, Slaters Rd, underside of leaves of $N$. truncata (NZAC); NN/BR, above Buller River, c. $7 \mathrm{~km}$ E of Lyell, undersides of leaves of N. fusca (ANIC); BR, Rahu Saddle, Klondyke Spur Tk, leaf of N. fusca (NZAC); BR, Lewis Pass National Park, Marble Hill, N. fusca in dimples on underside of leaves (NZAC); MC, Banks Peninsula, Hinewai Reserve, N. fusca in dimples on underside of leaves (NZAC).

\section{Remarks}

Hoy (1962a) inspected Maskell's duplicate material labelled as Rhizococcus pulchellus. All material collected from $N$. solandri he recognised as $M$. pulchellus [see explanation in notes for that species]. The material collected from $N$. fusca he described as a new species, $M$. viridulus. The two species are very similar [see comments under $M$. pulchellus] and both live on the leaves of their hosts (Fig. 4L). However, females of M. viridulus induce dimples on leaves, as described and illustrated by Henderson and Martin (2006), whereas females of M. pulchellus do not distort the foliage. The NZAC has several collections of specimens that are similar to $M$. viridulus except that the dorsal body setae of the adult female are mostly minute, with two longitudinal medial rows of enlarged medial setae extending from the head to the tip of the abdomen and three pairs of submedial enlarged setae on the thorax. These specimens are all from N. truncata in the East Cape (North Island) and Nelson (South Island) regions (see above for collection data), and there is a range of variation in size of the enlarged setae, with most specimens from the Nelson region being closer to $M$. viridulus than those from the East Cape. These differences may represent variation within $M$. viridulus, perhaps due to host-plant differences.

\section{Species excluded from Madarococcus}

\section{'Madarococcus' totarae (Maskell) incertae sedis}

Rhizococcus totarae Maskell, 1890: 142-143, fig. 65. Type data: New Zealand: South Island, near Reefton, on Podocarpus totara, viii.1889, W. M. Maskell. Lectotype female, by subsequent designation of Deitz \& Tocker, 1980: 49. Type depository: NZAC, USNM.

Nidularia totarae; Lindinger, 1933: 117. Change of combination.

Madarococcus totarae; Hoy, 1962a: 6, 151, 160-161. Change of combination.

\section{Material examined}

Material of typical form (some listed in Hoy (1962a) and some additional): New Zealand: AK, Waitakere Ra, Karamatura Stm, young stems of Podocarpus totara (NZAC); GB, Gisborne, on P. totara, (NZAC); TO, Ohakune, on $P$. totara (NZAC); NN, Nelson, on P. totara (NZAC); NN, Brightwater, ex $P$. totara (NZAC); NN, Motueka (NZAC); MC, Christchurch, Kennedy's Bush, on P. totara (NZAC).

Material of ' $M$.' nr totarae (some listed in Hoy (1962a) and some additional): New Zealand: AK, Riverhead Forest, Barlow Road Reserve, stems of $P$. totara (ANIC); TO, Murupara, on P. totara (NZAC); TO, Pureora Forest (NZAC); WN, Otaki Forks, on P. totara (NZAC); MC, Akaroa, Grehan Valley, on P. totara (NZAC).

\section{Remarks}

Hoy (1962a) illustrated and redescribed the adult female of this species based on one slide-mounted female from Maskell's col- lection (this female is now the lectotype) plus 44 other specimens collected subsequent to the original description. Maskell (1890) recorded this species from Podocarpus totara and sometimes on N. menziesii. Hoy noted that there were no specimens of this species from Nothofagus in Maskell's collection and that all subsequent records have been from podocarps. Thus it seems that Maskell's record from Nothofagus is erroneous. The entry for this species in ScaleNet (Miller and Gimpel 2007) and the recent world catalogue of Eriococcidae (Miller and Gimpel 2000) refers to paralectotypes in the USNM. The USNM has two slides (one with an adult female containing several embryos and the other with a piece of a pupa) (D. R. Miller personal communication). These have the Maskell Collection \# 108. There are no specimens with the number 108 in the Maskell collection in the NZAC and the type status of the USNM material is uncertain.

Examination of all NZAC specimens studied by Hoy as well as subsequent collections revealed adult females and first-instar nymphs of two morphological forms collected from $P$. totara throughout New Zealand. In the typical form (i.e. the same as the lectotype), the adult female and associated first-instar nymph have conical enlarged marginal setae but only minute dorsal setae (with the exception of on embryo among several on the slide from Kennedy's Bush, which has two dorsal mediolongitudinal rows of small conical setae). In contrast, on specimens referred to here as ' $M$.' $\mathrm{nr}$ totarae, there are conical enlarged setae, 10-15 $\mu \mathrm{m}$ long (similar to those on the margin), on the mediodorsal thorax and anterior abdomen of the adult female, and on the first-instar nymph, there are two mediolongitudinal rows of conical setae, with each seta slightly wider at the base than the marginal conical setae. The distributions of these two morphological forms display no obvious altitudinal or latitudinal pattern and it is possible that we are dealing with two distinct but very closely related species. The collection used for DNA sequencing belongs to ' $M$.' nr totarae, but we are confident that both the typical form and ' $M$.' $\mathrm{nr}$ totarae belong in the same clade based on their morphological similarity.

Phylogenetic analyses based on both morphological and molecular data place ' $M$.' $\mathrm{nr}$ totarae well outside of the Nothofagus-feeding clade of eriococcids. The suranal setae of adult females of ' $M$. ' totarae and ' $M$. ' $\mathrm{nr}$ totarae are not spatulate (mostly spatulate in Madarococcus), and only one size class of quinquelocular pores is present on the venter (two size classes present in all but one of the Madarococcus species lacking spatulate suranal setae). We here transfer ' $M$.' totarae out of Madarococcus and leave it unplaced (as incertae sedis) until its relationships can be better studied. It appears to be related to some other New Zealand species that feed on Podocarpaceae and currently are placed in Eriococcus. However the type species of Eriococcus, E. buxi (Boyer de Fonscolombe), is unrelated to the New Zealand Eriococcus species [see Cook et al. (2002) and Cook and Gullan (2004) for more information].

\section{Acknowledgements}

We gratefully acknowledge the contributions to Australian entomology made by the late Jack Beardsley, who collected specimens of each of the six Australian species described in this paper. We thank Cathy Young (Department of Primary Industries and Water, Tasmania) and Jane KebleWilliams (University of Tasmania) for the loan of Tasmanian eriococcids from Nothofagus. Dug Miller kindly provided information on the USNM 
holdings of Maskell specimens and arranged the loan of some type specimens. Jon Martin arranged the loan of and provided some information on BMNH specimens of Madarococcus. David Morris kindly provided sequence data for one collection. Many people assisted this research by collecting specimens. We especially thank Nicholas Martin who provided many eriococcid specimens to NZAC, Mike Crisp and David Morris for collecting galls on Nothofagus in Australia, and Demian Kondo for collecting the Chilean specimens used for the DNA work. We acknowledge the Chilean National Forests Corporation (CONAF) for collecting permits (held by PJG in 1996, E. Arias in 2003, T. Kondo in 2006). The Australian National Botanic Gardens (ANBG), Canberra, allowed PJG to collect scale insects and Stuart Donaldson (ANBG) provided assistance. Peter Cranston accompanied PJG on many field trips to collect Nothofagus-feeding eriococcids and Robert Hoare assisted PJG with fieldwork in New Zealand. Graeme Henderson accompanied RCH on field trips to collect scale insects in New Zealand. The following agencies/departments also provided collecting permits to PJG, LGC, RCH and their collaborators: the former Department of Parks, Wildlife and Heritage, and the current Department of Primary Industries and Water, Tasmania; New South Wales National Parks and Wildlife Service; State Forests of New South Wales; and the Department of Conservation, New Zealand. This work was supported by an Australian Biological Resources Study grant (1995-1998) to PJG; a National Science Foundation PEET grant (DEB-0118718) and by Hatch funding from the California Agricultural Experiment Station to PJG; the Foundation for Research, Science and Technology, New Zealand, under contract CO9X0501 to RCH; and an ARC Discovery Project grant to LGC.

\section{References}

Belshaw, R., and Quicke, D. L. J. (1997). A molecular phylogeny of the Aphidiinae (Hymenoptera: Braconidae). Molecular Phylogenetics and Evolution 7, 281-293. doi:10.1006/mpev.1996.0400

Ben-Dov, Y., Miller, D. R., and Gibson, G. A. P. (2007). 'ScaleNet, Scales on a Specified Host Query Results.' Available at http://www.sel.barc.usda.gov/scalenet/scalenet.htm [Verified 25 June 2007.]

Brower, A. V. Z., and DeSalle, R. (1998). Patterns of mitochondrial versus nuclear DNA sequence divergence among nymphalid butterflies: the utility of wingless as a source of characters for phylogenetic inference. Insect Molecular Biology 7, 73-82. doi:10.1046/j.1365-2583.1998. 71052.x

Cho, S., Mitchell, A., Regier, J. C., Mitter, C., Poole, R. W., Friedlander, T. P., and Zhao, S. (1995). A highly conserved nuclear gene for low-level phylogenetics: elongation-factor $1 \alpha$ recovers morphology-based tree for heliothine moths. Molecular Biology and Evolution 12, 650-656.

Cook, L. G., and Crisp, M. D. (2005). Not so ancient: the extant crown group of Nothofagus represents a post-Gondwanan radiation. Proceedings of the Royal Society of London. Series B. Biological Sciences 272, 2535-2544. doi:10.1098/rspb.2005.3219

Cook, L. G., and Gullan, P. J. (2004). The gall-inducing habit has evolved multiple times among the eriococcid scale insects (Sternorrhyncha: Coccoidea: Eriococcidae). Biological Journal of the Linnean Society $\mathbf{8 3}$, 441-452. doi:10.1111/j.1095-8312.2004.00396.x

Cook, L. G., Gullan, P. J., and Trueman, H. E. (2002). A preliminary phylogeny of the scale insects (Hemiptera: Sternorrhyncha: Coccoidea) based on nuclear small-subunit ribosomal DNA. Molecular Phylogenetics and Evolution 25, 43-52. doi:doi:10.1016/S1055-7903(02)00248-8

Crosby, T. K., Dugdale, J. S., and Watt, J. C. (1998). Area codes for recording specimen localities in the New Zealand subregion. New Zealand Journal of Zoology 25, 175-183.

Deitz, L. L., and Tocker, M. F. (1980). W.M. Maskell's Homoptera: speciesgroup names and type material. New Zealand Department of Scientific and Industrial Research. Information Series 146. pp. 1-76.

Fernald, M. E. (1903). A catalogue of the Coccidae of the world. Bulletin of the Hatch Experiment Station of the Massachusetts Agricultural College 88, $1-360$.
Gibbs, R. A., and Cockerill, M. (1995). 'Sequencher. Version 3.0.' (Gene Codes Corporation: Ann Arbor, MI, USA.)

Gonzalez, P. (2004). Eriococcidos (Hemiptera: Coccoidea) encontrados en la Patagonia, Argentina. Revista de la Sociedad Entomológica Argentina 63, 31-32.

Govaerts, R., and Frodin, D. (1998). 'World checklist and bibliography of Fagales (Betulaceae, Corylaceae, Fagaceae and Ticodendraceae).' (The Royal Botanic Gardens: Kew, UK.)

Granara de Willink, M. C., and Miller, D. R. (2004). Two new species of mealybugs (Hemiptera: Coccoidea: Pseudococcidae) from Patagonia, Argentina. Proceedings of the Entomological Society of Washington 106, $140-158$.

Gullan, P. J. (1984). A revision of the gall-forming coccoid genus Apiomorpha Rübsaaman (Homoptera: Eriococcidae: Apiomorphinae). Australian Journal of Zoology. Supplementary Series 97, 1-203.

Heads, M. (2006). Panbiogeography of Nothofagus (Nothofagaceae): analysis of the main species massings. Journal of Biogeography 33, 1066-1075. doi:10.1111/j.1365-2699.2006.01479.x

Henderson, R. C., and Martin, N. A. (2006). Review of the gall-inducing scale insects of New Zealand (Hemiptera: Coccoidea), with a guide to field identification. New Zealand Entomologist 29, 59-75.

Hill, R. S. (2001). Biogeography, evolution and palaeoecology of Nothofagus (Nothofagaceae): the contribution of the fossil record. Australian Journal of Botany 49, 321-332. doi:10.1071/BT00026

Hodgson, C. J., and Miller, D. R. (2002). A new genus and two new species of felt scales (Hemiptera: Coccoidea: Eriococcidae) from Chile, with comments on zoogeographical affinities between the eriococcid faunas of southern South America and New Zealand. Systematic Entomology 27, 191-209. doi:10.1046/j.1365-3113.2002.00174.x

Hoy, J. M. (1962a). Eriococcidae (Homoptera: Coccoidea) of New Zealand. New Zealand Department of Scientific and Industrial Research Bulletin 146, 1-219.

Hoy, J. M. (1962b). A new species of Eriococcus (Homoptera: Coccoidea) from Navarino Island, Tierra del Fuego. New Zealand Journal of Science $\mathbf{5}, 510-512$.

Huelsenbeck, J. P. (1991). When are fossils better than extant taxa in phylogenetic analysis? Systematic Zoology 40, 458-469. doi:10.2307/ 2992240

Humphries, C. J. (1981). Biogeographical methods amd the southern beeches (Fagaceae: Nothofagus). In 'Advances in Cladistics: Proceedings of the First Meeting of the Willi Hennig Society'. (Eds V. A. Funk and D. R. Brooks.) pp. 177-207. (The New York Botancial Garden: New York, USA.)

Humphries, C. J., Cox, J. M., and Nielsen, E. S. (1986). Nothofagus and its parasites: a cladistic approach to coevolution. In 'Coevolution and Systematics'. (Eds A. R. Stone and D. L. Hawksworth.) pp. 55-76. (Claredon Press: Oxford, UK.)

Knapp, M., Stöckler, K., Havell, D., Delsuc, F., Sebastiani, F., and Lockhart, P. J. (2005). Relaxed molecular clock provides evidence for long-distance dispersal of Nothofagus (southern beech). PLoS Biology 3, 38-43. doi:10.1371/journal.pbio.0030038

Kondo, T., Hardy, N., Cook, L., and Gullan, P. (2006). Descriptions of two new genera and species of Eriococcidae (Hemiptera: Coccoidea) from southern South America. Zootaxa 1349, 19-36.

Lewis, P. O. (2001). A likelihood approach to estimating phylogeny from discrete morphological character data. Systematic Biology 50, 913-925. doi: 10.1080/106351501753462876

Li, R. Q., Chen, Z. D., Lu, A. M., Soltis, D. E., Soltis, P. S., and Manos, P. S. (2004). Phylogenetic relationships in Fagales based on DNA sequences from three genomes. International Journal of Plant Sciences 165, 311-324. doi:10.1086/381920

Linder, H. P., and Crisp, M. D. (1995). Nothofagus and Pacific Biogeography. Cladistics 11, 5-32. doi:10.1111/j.1096-0031.1995. tb00002.x 
Lindinger, L. (1933). Beiträge zur Kenntnis der Schildläuse (Hemipt. Homopt., Coccid.). Entomologischer Anzeiger 13, 77-166. [In German]

Manos, P. S. (1997). Systematics of Nothofagus (Nothofagaceae) based on rDNA spacer sequences (ITS): taxonomic congruence with morphology and plastid sequences. American Journal of Botany 84, 1137-1155. doi: $10.2307 / 2446156$

Manos, P. S., and Steele, K. P. (1997). Phylogenetic analyses of higher Hamamelidae based on plastid sequence data. American Journal of Botany 84, 1407-1419. doi:10.2307/2446139

Manos, P. S., Soltis, P. S., Soltis, D. E., Manchester, S. R., Oh, S. H., Bell, C. D., Dilcher, D. L., and Stone, D. E. (2007). Phylogeny of extant and fossil Juglandaceae inferred from the integration of molecular and morphological datasets. Systematic Biology 56, 412-430. doi:10.1080/ 10635150701408523

Maskell, W. M. (1890). Further notes on Coccidae, with descriptions of new species from Australia, Fiji, and New Zealand. Transactions and Proceedings of the New Zealand Institute 22, 133-156.

Maskell, W. M. (1891). Further coccid notes: with descriptions of new species from New Zealand, Australia, and Fiji. Transactions and Proceedings of the New Zealand Institute 23, 1-36.

Maskell, W. M. (1892). Further coccid notes: with descriptions of new species, and remarks on coccids from New Zealand, Australia and elsewhere. Transactions and Proceedings of the New Zealand Institute 24, $1-64$.

McQuillan, P. B. (1993). Nothofagus (Fagaceae) and its invertebrate faunaan overview and preliminary synthesis. Biological Journal of the Linnean Society 49, 317-354.

Miller, D. R., and Gimpel, M. E. (1996). Nomenclatural changes in the Eriococcidae (Homoptera: Coccoidea). Proceedings of the Entomological Society of Washington 98, 597-606.

Miller, D. R., and Gimpel, M. E. (2000). 'A Systematic Catalogue of the Eriococcidae (Felt Scales) (Hemiptera: Coccoidea) of the World.' (Intercept Ltd: Andover, UK.)

Miller, D. R., and Gimpel, M. E. (2007). 'ScaleNet, Madarococcus totarae.' Available at http://www.sel.barc.usda.gov/catalogs/eriococc/Madarococ custotarae.htm [Verified 6 July 2007]

Miller, D. R., and González, R. H. (1975). A taxonomic analysis of the Eriococcidae of Chile. Revista Chilena de Entomologia 9, 131-163.

Miller, D. R., and McKenzie, H. L. (1967). A systematic study of Ovaticoccus Kloet and its relatives, with a key to North American genera of Eriococcidae (Homoptera: Coccoidea: Eriococcidae). Hilgardia 38, 471-539.

Posada, D., and Crandall, K. A. (1998). Modeltest: testing the model of DNA substitution. Bioinformatics (Oxford, England) 14, 817-818. doi:10.1093/bioinformatics/14.9.817
Rambaut, A. (1998). 'Se-Al (Sequence Alignment Editor Version 1.0 alpha 1).' Available at http://evolve.zps.ox.ac.uk. [Verified 12 May 2008.]

Ronquist, F., and Huelsenbeck, J. P. (2003). MRBAYES 3: Bayesian phylogenetic inference under mixed models. Bioinformatics 19, 1572-1574. doi:10.1093/bioinformatics/btg180

SanMartín, I., and Ronquist, F. (2004). Southern Hemisphere biogeography inferred by event-based models: plant versus animal patterns. Systematic Biology 53, 216-243. doi:10.1080/10635150490423430

Springer, M. S., Teeling, E. C., Madsen, O., Stanhope, M. J., and de Jong, W. W. (2001). Integrated fossil and molecular data reconstruct bat echolocation. Proceedings of the National Academy of Sciences of the United States of America 98, 6241-6246. doi:10.1073/pnas.111551998

Sunnucks, P., and Hales, D. F. (1996). Numerous Transposed sequences of mitochondrial chytochrome oxidase I-II in aphids of the genus Sitobion (Hemiptera: Aphididae). Molecular Biology and Evolution 17, 510-524.

Swofford, D. L. (2003). 'PAUP*. Phylogenetic Analysis Using Parsimony (* and Other Methods) Version 4.' (Sinauer Associates: Sunderland, MA, USA.)

Tautz, D., Hancock, J. M., Webb, D. A., Tautz, C., and Dover, G. A. (1988). Complete sequences of the rRNA genes of Drosophila melanogaster. Molecular Biology and Evolution 5, 366-376.

Torre-Bueno, J. R. de la, (1989). 'The Torre-Bueno Glossary of Entomology.' Compiled by S. W. Nichols with Supplement A by G. S. Tulloch. (New York Entomological Society: New York, USA.)

von Dohlen, C. D., and Moran, N. A. (1995). Molecular phylogeny of the Homoptera: a paraphyletic taxon. Journal of Molecular Evolution 41, 211-223. doi:10.1007/BF00170675

Wiens, J. J. (2003). Missing data, incomplete taxa, and phylogenetic accuracy Systematic Biology 52, 528-538. doi:10.1080/10635150390 218330

Williams, D. J. (1985a). Some South American scale insects (Homoptera: Coccoidea) on Nothofagus. Journal of Natural History 19, 249-258. doi:10.1080/00222938500770201

Williams, D. J. (1985b). The British and some other European Eriococcidae (Homoptera: Coccoidea). Bulletin of the British Museum Natural History 51, 347-393. [Entomology]

Williams, D. J. (2007). Scale insects of the families Asterolecaniidae and Eriococcidae (Hemiptera: Coccoidea) in New Caledonia. Journal of Natural History 41, 1343-1366. doi:10.1080/00222930701425498

Manuscript received 11 July 2007, accepted 28 February 2008 


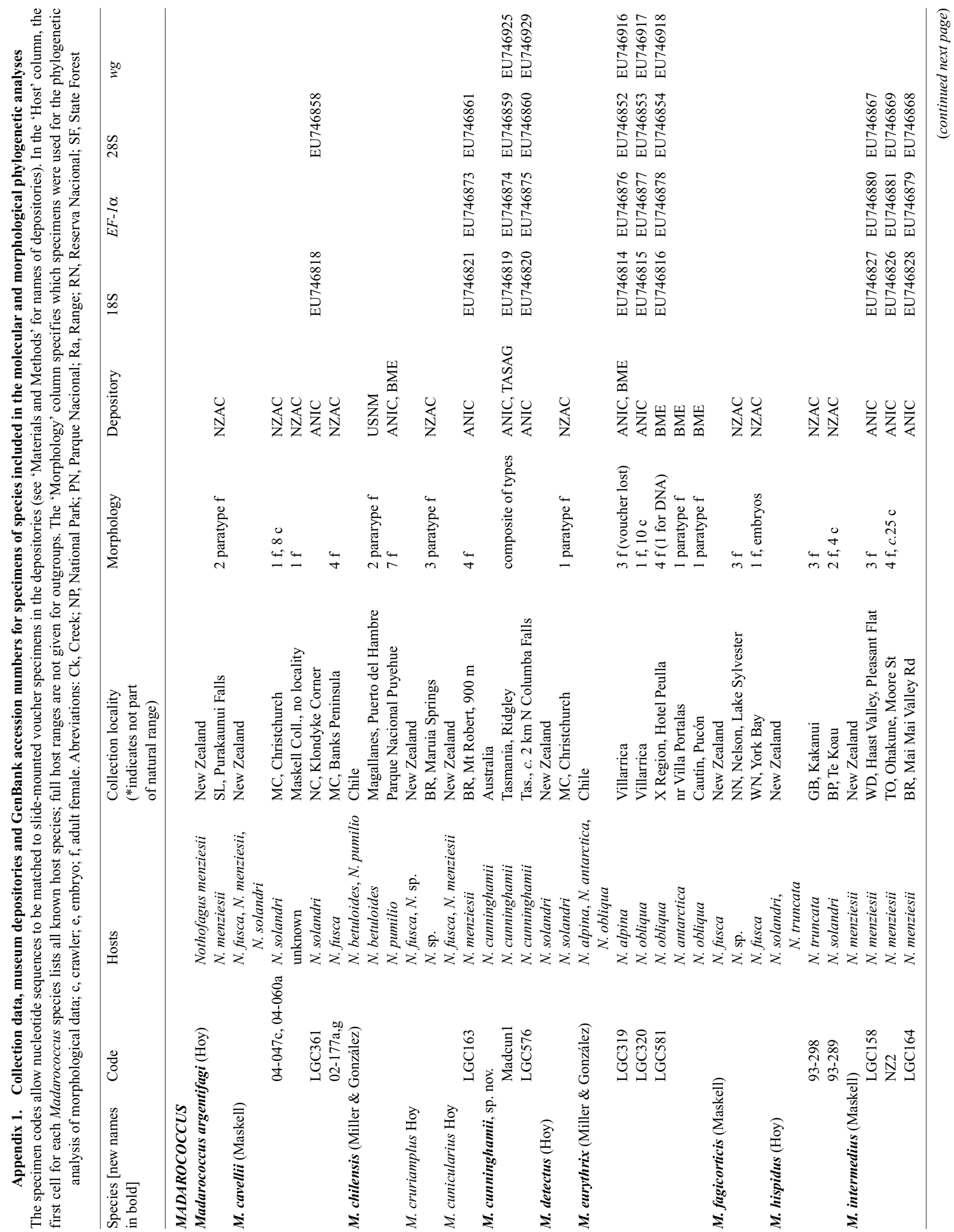




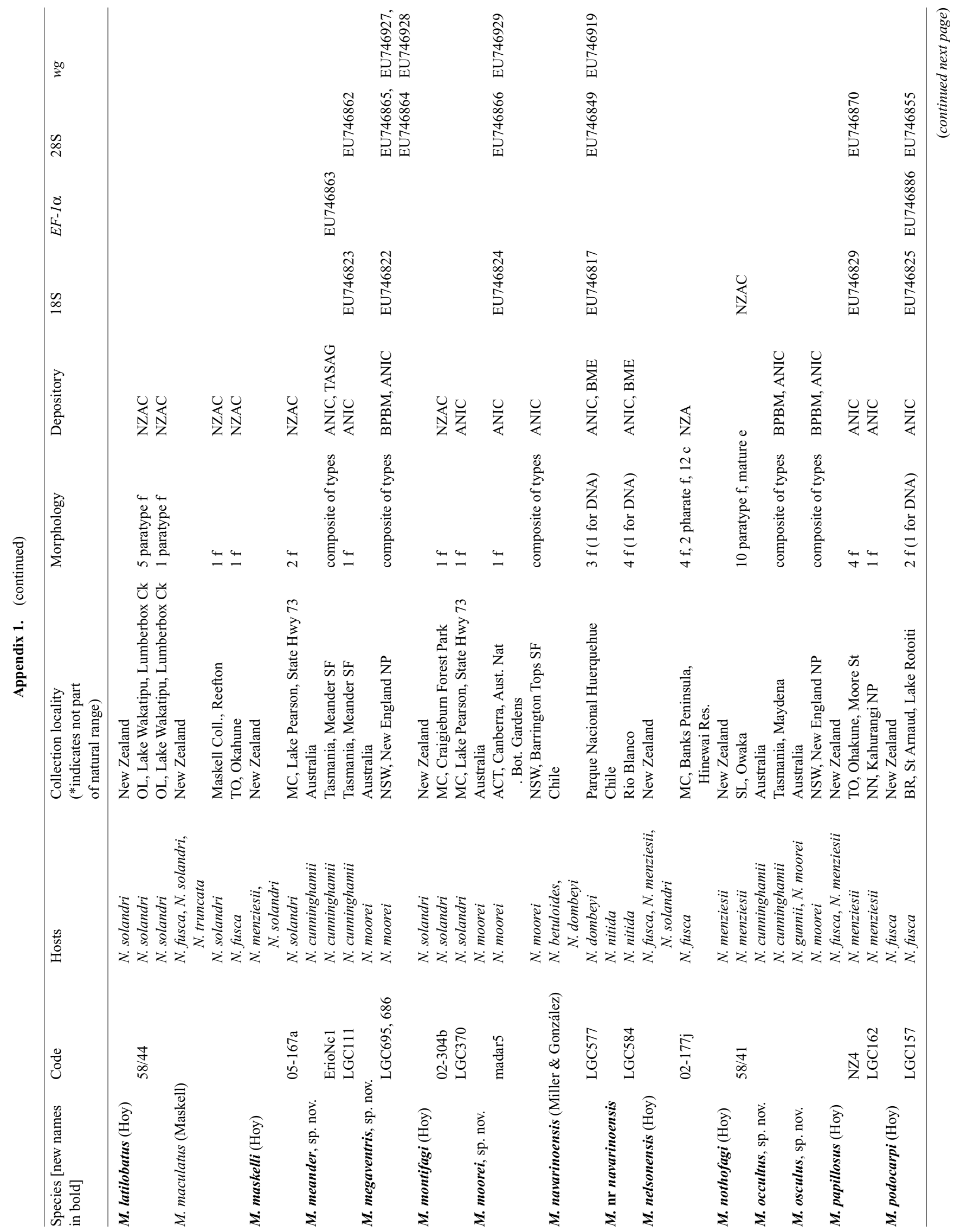




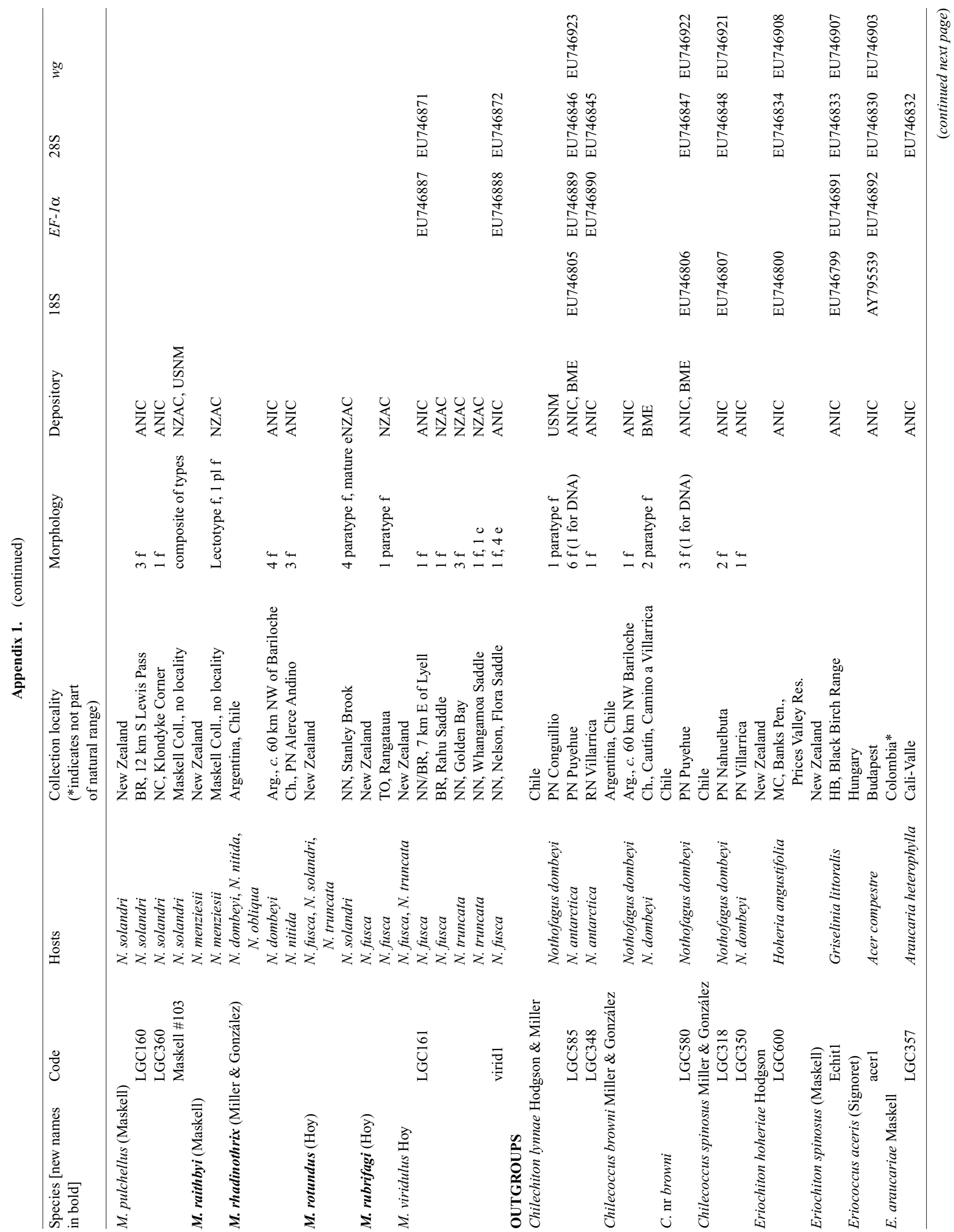




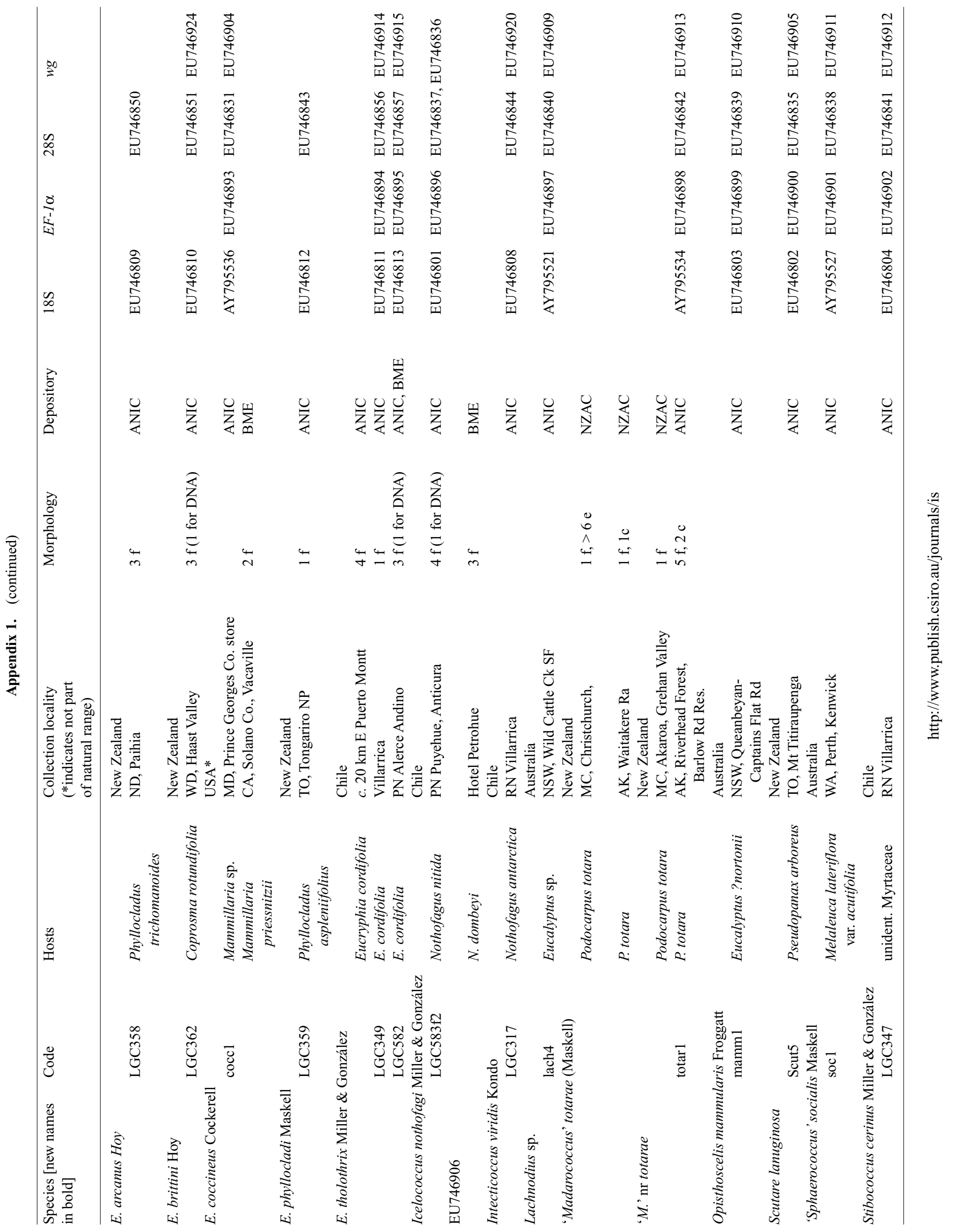

